(2) norden 



\section{Effektivare multilaterala insatser i östersjöregionen och dess närområde}


Effektivare multilaterala insatser i östersjöregionen och dess närområde

TemaNord 2007:554

(C) Nordiska ministerrådet, Köpenhamn 2007

ISBN 978-92-893-1534-0

Tryck: Ekspressen Tryk \& Kopicenter

Upplaga: 150

Tryckt på miljövänligt papper som uppfyller kraven i den nordiska miljösvanemärkningen.

Publikationen kan beställas på www.norden.org/order. Fler publikationer på

www.norden.org/publikationer

Printed in Denmark

Nordiska ministerrådet

Store Strandstræde 18

DK-1255 Köpenhamn K

Telefon (+45) 33960200

Fax (+45) 33960202

www.norden.org

\section{Nordiska rådet}

Store Strandstræde 18

DK-1255 Köpenhamn K

Telefon (+45) 33960400

Fax (+45) 33111870

\section{Det nordiska samarbetet}

Det nordiska samarbetet är ett av världens mest omfattande regionala samarbeten. Det omfattar Danmark, Finland, Island, Norge och Sverige samt de självstyrande områdena Färöarna, Grönland och Åland.

Det nordiska samarbetet är politiskt, ekonomiskt och kulturellt förankrat och är en viktig partner i europeiskt och internationellt samarbete. Den nordiska gemenskapen arbetar för ett starkt Norden i ett starkt Europa.

Det nordiska samarbetet vill styrka nordiska och regionala intressen och värderingar i en global omvärld. Gemensamma värderingar länderna emellan bidrar till att stärka Nordens ställning som en av världens mest innovativa och konkurrenskraftiga regioner. 


\section{Innehållsförteckning}

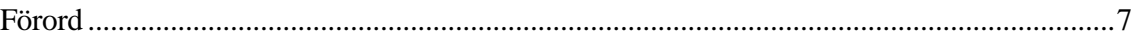

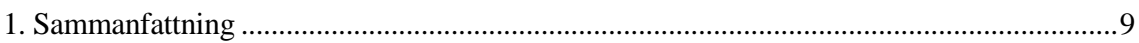

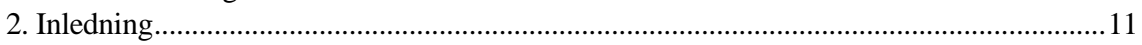

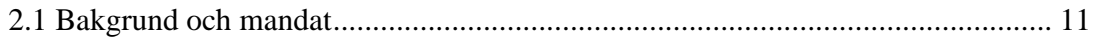

2.2 Närmare uppläggning av rapporten ................................................................. 12

2.3 IFIs komparativa fördelar ........................................................................... 14

3. Förstärkt nordisk IFI-samordning - åtgärder för att öka den nordiska slagkraften i IFIs med betoning på verksamhet i Östersjöregionen och dess närområde ....................................17

3.1 Den nordiska IFI-samordningen idag - problem och brister ............................... 18

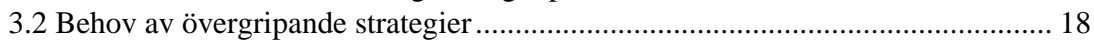

3.3 Behov av förstärkt nationell koordinering ........................................................ 19

3.4 Behov av omläggning av beredningsarbetet gentemot IFIs ................................... 20

3.5 Behov av ökat lateralt tänkande.......................................................................... 21

4. Grundläggande förutsättningar för additionella nordiska satsningar i anknytning till

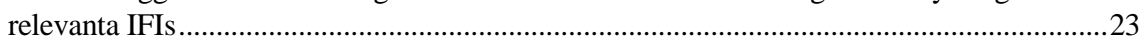

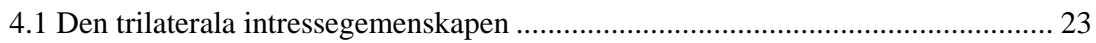

4.2 Interaktionen mellan regionala fora och IFIs....................................................... 27

5. Tänkbara samarbetsområden med IFI-involvering ............................................................. 31

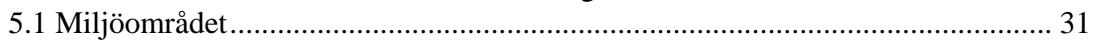

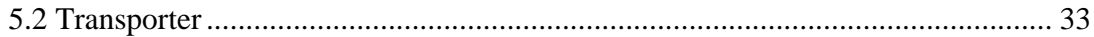

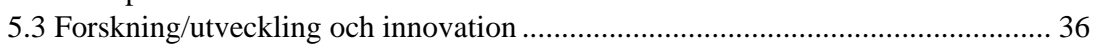

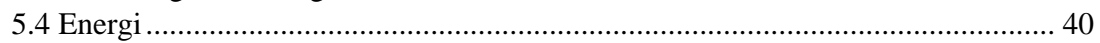

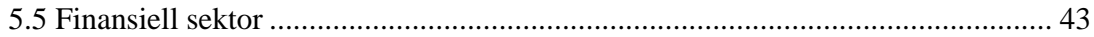

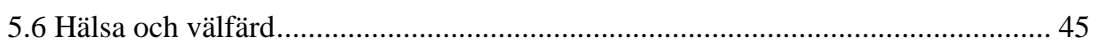

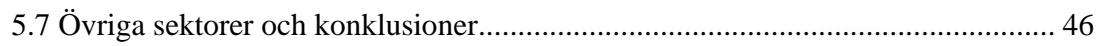

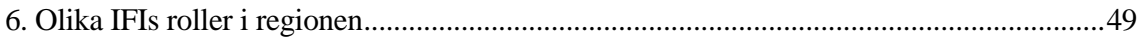

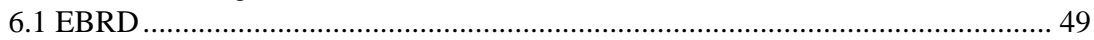

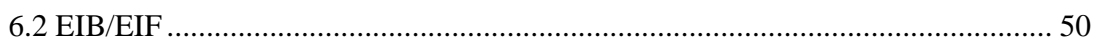

6.3 Världsbanksgruppen (IBRD, IFC, MIGA) ………………………….............. 53

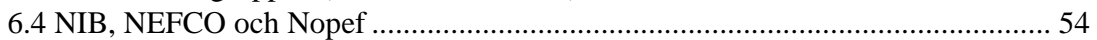

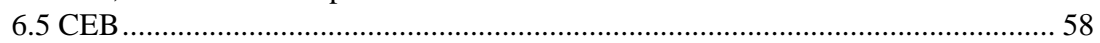

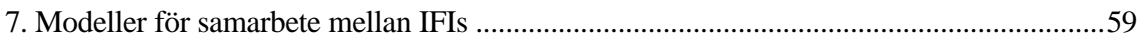

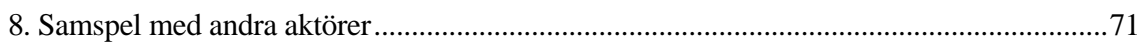

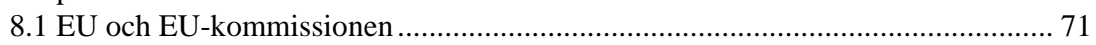

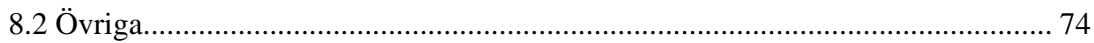

9. Behov av riktade insatser avseende enskilda länder eller delregioner ..................................77

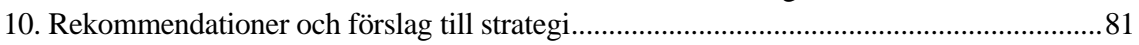

11. Summary of the Nordic Inquiry on More Efficient Multilateral Action in the Baltic Sea

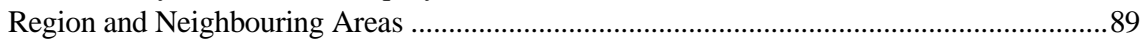

Bilaga 1 - Förkortningar ......................................................................................................93

Bilaga 2 - Korta fakta om IFIs som verksamma i östersjöregionen och dess närområden....95

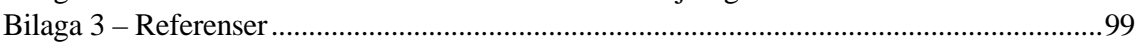





\section{Förord}

Nordiska ministerrådet beslutade i oktober 2005 att låta utreda de multilaterala institutionernas verksamhet i Östersjöregionen i syfte att klarlägga möjligheterna för en effektivare användning av dessa institutioners kompetens och resurser. Bakgrunden kan sägas vara ett allmänt behov av att vitalisera de nordiska ländernas agerande inom de internationella finansiella institutionerna (IFIs). För att få en rimlig avgränsning koncentrerades utredningen till det geografiska område som är av särskilt intresse för Norden, d.v.s. Östersjöregionen och dess närområde. De stora politiska och ekonomiska förändringar som inträffat i denna region under senare år, framför allt genom utvidgningen av EU, gör det också motiverat att på nytt granska hur Norden - eller andra konstellationer som Norden och Baltikum - kan använda de internationella organen för att påskynda den ekonomiska integrationen. En annan angelägen förändring är att få till stånd ett bättre fungerande samarbete mellan de många regionala organen och IFIs.

Utredningen utmynnar i ett förslag till nordisk strategi som berör ett mycket stort antal frågor. Denna mångfald kan vara svår att hantera, men den är nödvändig eftersom IFIs verksamhet spänner över så många olika områden. Det utpräglade revirtänkande som kännetecknar framför allt kontakterna mellan ansvariga ministerier i de nordiska länderna skapar dessutom onödiga hinder för en angelägen helhetssyn. En mera flexibel och konstruktiv hållning som ser till övergripande intressen framstår som angelägen.

Fördjupad nordisk samverkan kan därutöver ge betydande vinster. Det finns självfallet ingen anledning för de nordiska länderna att samverka i eller med IFIs för samverkans egen skull. Här, liksom i all annan nordisk verksamhet, måste "den nordiska nyttan” vara vägledande. Rapportens huvudkonklusion är att det finns betydande möjligheter att vinna fördelar såväl för Norden som för hela regionen genom att utveckla IFIsamarbetet och dessutom göra additionella insatser i anknytning till IFIs aktiviteter.

Föreliggande rapport är en enmansutredning som baseras på ett omfattande material från överläggningar med företrädare för departement och myndigheter i regionens länder, för de internationella institutionerna, för den privata sektorn samt för olika fristående nätverk. En närmare beskrivning återfinns i bilaga 3, Referenser. Rapporten har också diskuterats vid möten i nordiska beredningsorgan, främst ämbetsmannakommittén för ekonomiska och finansiella frågor (ÄK-finans). Även andra berörda ämbetsmannakommittéer har beretts möjlighet att lämna synpunkter. De 
rekommendationer och förslag som framförs är dock utredarens egna och skall inte ses som resultatet av en nordisk samordning.

Stockholm den 21 juni 2007

Sven-Olof Johansson

Finansråd 


\section{Sammanfattning}

Utredningen, som har utförts på uppdrag av Nordiska ministerrådet, syftar till att presentera ett samlat förslag till strategi för de nordiska ländernas medverkan i multilaterala aktiviteter i den aktuella regionen. Intresset inriktas primärt på de viktigaste internationella finansiella institutionerna (IFIs) såsom Europeiska utvecklingsbanken, Europeiska investeringsbanken, Världsbanksgruppen, Nordiska investeringsbanken, Nordiska miljöfinansieringsbolaget och Europarådets utvecklingsbank. Dessutom behandlas relationerna till andra viktiga aktörer som EU-kommissionen och samarbetet i de många regionala organen.

Bakgrunden till utredningen är den fortgående ekonomiska och finansiella integrationen i Östersjöområdet som accelererat särskilt genom utvidgningen av EU. En annan väsentlig nyhet är överenskommelsen om ett permanent samarbete inom den Nordliga dimensionens ram där samtliga nordiska länder ingår som fullvärdiga deltagare. Pågående förändringar påverkar IFIs verksamhet och kräver en närmast kontinuerlig anpassning. Estland, Lettland och Litauen har redan beslutat att upphöra med upplåning från Världsbanken. I Europeiska utvecklingsbanken finns en överenskommen plan för avvecklingen av bankens verksamhet i EUs nya medlemsländer. Parallellt härmed ökar Europeiska investeringsbankens betydelse som finansiär både inom och utanför EU. Tidpunkten är därför lämplig för en bred översyn av de nordiska ländernas samarbete inom och med IFIs i syfte att finna former för effektiv resursanvändning och innovativa lösningar. Dessutom finns det ett behov av en helhetssyn på de multilaterala satsningar som Norden bidrar till i regionen.

Utredningens rekommendationer är indelade i ett flertal olika avsnitt. I ett första avsnitt framläggs förslag till ett mera proaktivt och målinriktat agerande inom IFIs. Det föreslås att en profilhöjning baseras på övergripande nationella strategier och på samnordiska policydokument. Styrelserepresentanterna i IFIs bör ges ökad frihet att agera inom ramen för gemensamma policyinitiativ. Vikten av ett starkt förbättrat samråd mellan berörda ministerier inom varje land betonas också. Kvardröjande revirstrider försvagar de nordiska ländernas möjligheter att få genomslag för sina synpunkter.

I ett andra avsnitt presenteras förslag avseende prioriteringen av sakområden. Tre områden lyfts fram: miljö, transporter och "klustret" forskning/utveckling/innovation. Inom miljöområdet betonas vikten av att bygga vidare på Nordliga dimensionens miljöpartnerskap och att utveckla Nordiska miljöfinansieringsbolagets verksamhet. Inom transportsektorn rekommenderas de nordiska länderna stödja initiativet om ett särskilt partnerskap för transport och logistik. På innovationsområdet föreslås att 
nordiska (eller nordisk-baltiska) riskkapitalfonder inrättas i såväl Europeiska investeringsfonden som Europeiska utvecklingsbanken. Även på andra sakområden framläggs konkreta förslag men då i huvudsak som punktinsatser.

Den tredje delen av utredningens förslag avser enskilda IFIs roller i regionen. Det förstärkta samarbetet mellan vissa europeiska IFIs välkomnas. Detta samarbete får dock inte leda till att andra institutioner "hålls utanför" viktiga projekt. De nordiska länderna har ett intresse av att alla finansiärer med relevant kompetens kan verka i regionen. Världsbanksgruppen är fortsatt en viktig aktör i länder som Ryssland och Ukraina. Av särskild betydelse är också att Nordiska investeringsbanken får utrymme för sin verksamhet som - enligt utredningens syn - bör gå i riktning mot ökad specialisering. En ökad integrering inom den nordiska finansgruppen är också angelägen.

I ett fjärde avsnitt behandlas IFI-samordningen och samspelet med andra aktörer. Utgångspunkten för Norden bör vara ett systemorienterat synsätt. IFIs verksamhet bör styras av de egna organen och inte dikteras av separata fonder med egen beslutsstruktur. Fristående intressenter och nätverk bör utnyttjas mera än hittills, kanske särskilt i länder som är relativt "passiva" deltagare i det regionala samarbetet. Dessutom bör informationen till och kontakterna med privata aktörer och finansiärer stärkas i syfte att uppnå de katalytiska effekter som IFI-medverkan öppnar möjligheter för. I ett femte avsnitt tas specifika geografiska prioriteringar upp. Det föreslås att riktade insatser övervägs framför allt gentemot Ukraina och Kaliningrad-området.

När det gäller utredningens fortsatta behandling förordas att ett eventuellt ministerbeslut om en förnyad strategi kombineras med ett beslut om formerna för uppföljning. Utredningen rekommenderar att strategins genomförande allmänt följs upp av ÄK-finans. Ansvaret för implementeringen av strategins olika delar måste dock primärt ligga på de nationella förvaltningarna med samtidigt utnyttjande av de nordiska samrådsorgan som redan finns, t.ex. för vissa IFIs. I vissa fall kommer beredningen av förslagen att ta relativt lång tid. Det gäller särskilt de förslag som måste bygga på en trilateral intressegemenskap mellan de nordiska länderna, de länder som berörs av de nya satsningarna och de IFIs som involveras. På dessa punkter krävs det ingående överläggningar mellan de tre parterna innan konkreta förslag kan presenteras för godkännande. Utredningen förordar att ÄK-finans återrapporterar till Ministerrådet (finansministrarna) ett år efter det att ett övergripande strategiförslag har antagits. 


\section{Inledning}

\subsection{Bakgrund och mandat}

Utredningens allmänna bakgrund är den snabba förändringsprocessen i Östersjöregionen, i synnerhet den fortgående ekonomiska och finansiella integrationen. Ett av de instrument som kan utnyttjas för att främja denna integration är de internationella finansiella institutionernas (IFI) resurser. Flertalet transitionsländer i det nordiska närområdet har nu nått så långt $\mathrm{i}$ den ekonomiska omvandlingsprocessen att det finns anledning att på nytt granska hur det externa stödet bör utformas. Utredningen utgår från en helhetssyn på de multilaterala satsningar som Norden medverkar i både i Östersjöregionen och dess närområde. Den knyter an till de handlingsprogram som utarbetas i olika regionala organ eller inom ramen för samarbetet i Nordliga dimensionen.

I centrum för uppmärksamheten står IFIs som Europeiska utvecklingsbanken, EBRD, Europeiska investeringsbanken, EIB, Europeiska investeringsfonden, EIF, Nordiska investeringsbanken, NIB, Nordiska miljöfinansieringsbolaget, NEFCO, Nordiska projektfonden, Nopef, Världsbanksgruppens delar IBRD, IFC och MIGA samt Europarådets utvecklingsbank, CEB. Samtliga dessa institutioner är redan viktiga aktörer i det ekonomiska och finansiella samarbetet i Östersjöregionen och dess närområde, men det krävs en kontinuerlig anpassning av deras insatser för att de fortsatt skall vara effektiva. De nordiska länderna har med sitt starka engagemang för regionens utveckling särskilt goda förutsättningar att vara pådrivande på detta område.

Utredningen inleds med en generell genomgång av förutsättningarna för ett mera målinriktat och verkningsfullt nordiskt agerande i IFIs. Kan nuvarande nordiska eller nordisk/baltiska samordningen, som det inte finns anledning att ifrågasätta i sig, göras mera effektiv? Utredningens uppfattning är att vi i Norden bör kunna agera mera proaktivt på grundval av genomarbetade nationella strategier och gemensamma policydokument. Den nuvarande försiktigheten, som bland annat innebär att vänta med inspel till ett mycket sent stadium i beslutsprocessen, bör omprövas. I stället bör våra företrädare ges ökade möjligheter att söka påverka besluten genom fördjupade kontakter med de ansvariga i IFIs.

De nordiska länderna bör dessutom i större utsträckning än hittills uppmärksamma frågor som direkt följer av ägarrollen i IFIs. Betydande kapitalresurser har ställts till IFIs förfogande, om än huvudsakligen i form av garantikapital. Det behövs en mer transparent och regelbunden redovisning av hur dessa resurser utnyttjas mot bakgrund av våra allmänna prioriteringar för samarbetet. Ansvaret för denna redovisning ligger i 
första hand på det nationella planet. Det kan dock vara värdefullt med en långtgående nordisk samsyn om principerna för redovisningen. Dessa frågor har redan uppmärksammats av nationella revisionsorgan.

Huvuddelen av utredningens rapport ägnas åt tänkbart samarbete mellan de nordiska länderna och olika IFIs i Östersjöregionen och dess närområde. Utgångspunkten är en kritisk granskning av de olika fora och initiativ som de nordiska länderna medverkar i. Avsikten är inte att sätta betyg utan att försöka ge underlag för bedömningar av vad som fungerar respektive inte fungerar. Det finns en kvardröjande högaktningsfullhet i det regionala samarbetet som tar sig uttryck i att uppenbara svagheter förtigs. En sådan attityd motverkar effektiv resursanvändning.

Därefter behandlas frågor som gäller vilka sektorer eller geografiska områden som skall prioriteras, hur IFIs verksamhet skall relateras till annan nordisk eller annan multilateral verksamhet exempelvis i diverse regionala organ, hur ökad samverkan mellan och inom IFIs skall främjas och hur deras verksamhet skall kopplas till andra aktörers aktiviteter i både offentlig och privat sektor. Syftet är genomgående att peka på tänkbara åtgärder som kan bidra både till verkningsfullare multilaterala insatser och till att höja utväxlingen på de nordiska bidragen. Som framhölls i projektbeskrivningen är avsikten primärt att finna former för bättre användning av redan avsatta resurser. På specifika punkter - och under förutsättning av ett tydligt mervärde - finns det dock anledning att överväga additionella samnordiska insatser. Med undantag för miljöområdet, där substantiella gåvobidrag kan anses motiverade, är det fråga om klart begränsade belopp som vanligen avser kompletterande tekniskt bistånd.

Rapporten utmynnar i ett förslag till strategi i form av en serie konkreta rekommendationer som sammanfattas i avsnitt 10 . Syftet med dessa rekommendationer är att de skall tjäna som vägledning för det framtida nordiska agerandet.

\subsection{Närmare uppläggning av rapporten}

Rapporten koncentreras till tänkbara samarbetsmöjligheter mellan de nordiska länderna och olika IFIs. Denna koppling bestämmer uppläggningen. Enskilda nordiska länders samarbete med IFIs faller exempelvis utanför ramen för genomgången. Samtidigt bör redan inledningsvis sägas att beteckningen samnordisk eller gemensamt nordisk på många punkter kan innefatta också de tre baltiska länderna. Detta framstår som självklart i institutioner som Världsbanken där samtliga nordiska och baltiska länder ingår i samma valkrets. Även i andra IFIs har ett långtgående samarbete utvecklats, vilket emellanåt fått formen av att ett eller två nordiska länder bildat valkrets med ett baltiskt land (exempelvis EBRD). Detta betyder att mycket av det som nedan föreslås under avsnitt 3 om förstärkt nordisk IFI-samordning också direkt berör de baltiska länderna. 
Läget är emellertid ett annat när det gäller en direkt samverkan med enskilda IFIs inom ramen för separata satsningar eller projekt. Deltagande i ett sådant fördjupat samarbete med flertalet IFIs, innefattande olika former av additionella insatser, är inte något som följer av valkretstillhörighet utan en sak för Estland, Lettland och Litauen att ta ställning till i särskild ordning. Med tanke på detta och på att utredningen utförts på uppdrag av NMR utan medverkan från baltiskt håll har vanligen valts att referera till det nordiska samarbetet. Även när det gäller IFI-samverkan finns det dock undantag. Det viktigaste gäller NIB som är en tidigare nordisk institution i vilken de tre baltiska länderna numera är medlemmar.

Genomgångar görs såväl områdesvis som institutionsvis. Den valda uppläggningen innebär att utredaren valt att avstå från att tynga framställningen med detaljerade bakgrundsredovisningar av alla sakområden eller med statistiska och andra fakta om de aktuella finansiella institutionerna och deras verksamhet. ${ }^{1}$ Fokus ligger i stället på de aktiviteter och frågeställningar som är aktuella i dag och under de närmaste åren. Inom denna mera begränsade ram finns kortfattade beskrivningar av vad som för närvarande sker i det multilaterala finansiella samarbetet.

En ytterligare avgränsning är att rapporten inte tar upp enskilda projekt inom olika sektorer. Genomförda eller pågående projekt redovisas utförligt på respektive institutions hemsidor eller i sammanställningar som gjorts främst av EU-kommissionen i anknytning till Nordliga dimensionen eller till arbetet om transeuropeiska nätverk. När det gäller framtida projekt kräver konkreta förslag en detaljgranskning av förutsättningarna i det enskilda fallet som inte varit möjlig inom ramen för utredningen. I stället begränsas framställningen till att ange vilka sakområden som förefaller vara av särskilt intresse för ett samarbete mellan de nordiska länderna och IFIs.

I geografiskt avseende innefattas samtliga länder kring Östersjön samt Norge och Island. Tillägget "närområdet" avser att ta med även Vitryssland och Ukraina. När det gäller Ryssland ligger betoningen på federationens nordvästra delar, men en stor del av IFIs verksamhet avser projekt som överenskommits med den federala regeringen och som i princip täcker hela landet.

Slutligen bör framhållas att utredningen avsiktligt undviker att ta upp frågan vilka nationella budgetmedel som kan eller bör utnyttjas för olika typer av additionella nordiska insatser i anknytning till IFIs verksamhet. En vanlig missuppfattning i diskussioner kring utredningen är att snart sagt varje referens till tänkbart stöd, bidrag etc skulle avse bistånd i traditionell mening (enligt internationella riktlinjer). Så är givetvis inte fallet. Det finns betydande skillnader mellan de nordiska ländernas finansiering av existerande - och framtida - Östersjösamarbete och det är upp till varje land att avgöra hur eventuella additionella satsningar skall täckas. Utredaren är väl medveten om den omläggning som pågått sedan några år

\footnotetext{
${ }^{1}$ En kort presentation av aktuella IFIs finns i bilaga 2.
} 
innebärande att utrymmet för gåvostöd blir allt mindre när det gäller projekt i de baltiska länderna, Polen och numera även Ryssland.

\subsection{IFIs komparativa fördelar}

Som närmare berörs nedan är det långsiktiga målet för de offentligägda internationella finansinstitutionerna att göra sig själva överflödiga. Tidsperspektiven är dock varierande med avseende på såväl samarbetsländer som typ av verksamhet. Fattiga u-länder kommer att behöva stöd från IFIs under överskådlig tid. De utvecklade länder som står i centrum för denna rapport har däremot redan upphört med att utnyttja vissa IFIs finansiella resurser eller är inne i en process karakteriserad av successiv neddragning av sådan upplåning. Samtidigt har många av dem fortsatt behov av att utnyttja institutionernas kompetens när det gäller policyrådgivning, specifikt tekniskt stöd m.m.

Takten i den långsiktiga avvecklingen av delar av verksamheten är givetvis också beroende avvarje institutions specifika mandat och inriktning. EIB, vars främsta syfte är att medverka till att främja en balanserad utveckling och regional sammanhållning i EU, kommer att vara en viktig finansiär under en lång tid framöver. EBRD däremot, som skall underlätta övergången till marknadsekonomi och demokrati i ett antal tidigare planekonomier, måste planera för en kortare verksamhetsperiod, såvida inte bankens geografiska mandat utvidgas.

Det är dessutom viktigt att understryka att de internationella finansinstitutionerna är ett av flera instrument för att påskynda utveckling och ekonomiska reformer och att de kan och bör bedriva sin verksamhet parallellt med en rad andra aktörer, såväl offentliga som privata. I tekniskt avseende regleras detta genom att samtliga IFIs har regler som anger hur stor del av ett projekts samlade finansieringsbehov som de kan täcka. Under goda förutsättningar kompletterar de olika aktörerna varandra och ger ett större utbyte totalt sett för mottagarländerna och för världsekonomin i stort.

I vissa länder, även i Norden, finns det hos nationella myndigheter en tydlig skepsis mot att samarbeta med internationella finansiella organ. Ett vanligt argument är att sådant samarbete blir komplicerat på grund av alla de krav som IFIs ställer på projektets utformning och på övriga medverkande. Denna attityd underblåses emellanåt av fyrkantiga nationella regler, vilka gör att samfinansiering med IFIs överhuvudtaget inte övervägs. För att bidra till en bättre förståelse av IFIs roll kan det finnas skäl att här sammanfatta deras komparativa fördelar som det kan sägas råda bred enighet om, åtminstone om man utgår från att en välfungerande marknadsekonomi är ett eftersträvansvärt mål. Fördelarna är att IFIs kan: 
- ge tillgång till finansiering för länder som inte kan låna alls från andra källor eller som inte kan erhålla godtagbara villkor

- främja en stabilitetsorienterad politik och uppbyggnaden av fungerande institutioner och marknader, t.ex. en inhemsk kapitalmarknad

- förbättra kvaliteten i enskilda projekt alltifrån berednings- till genomförandefas

- leverera en "godkännandestämpel" som i sin tur ger katalytiska effekter i form av kompletterande resurstillskott från bilaterala aktörer, kapitalmarknaden etc.

- medverka till positiva spridningseffekter till andra sektorer i ett verksamhetsland eller till andra länder

- understödja efterlevnaden av internationellt överenskomna koder och standards

- spela en speciellt konstruktiv roll i gränsöverskridande projekt med regionala eller t.o.m. globala återverkningar. Inom miljö- och infrastrukturområdet finns åtskilliga sådana exempel. IFIs kan även underlätta gränsöverskridande privata investeringar, inte minst genom olika former av riskdelning.

Den katalytiska effekten går även i den andra riktningen innebärande att finansiella bidrag från en grupp medlemsstater kan mobilisera parallellfinansiering från IFIs som ofta blir betydligt större än medlemsbidragen. För de nordiska länderna - som partners till IFIs - kan satsningar i Östersjöregionen och närområdet också ge ökade möjligheter för de egna företagen att delta i de projekt som finansieras. Eftersom det på vissa områden rör sig om mycket stora projekt där nordiska företag dessutom är klart konkurrenskraftiga kan den totala effekten av samnordiska insatser bli betydande. Till detta skall läggas att IFIs har en privilegierad status som fordringsägare, vilket andra långivare som deltar i specifika former av samfinansiering kan ha utbyte av. 



\section{Förstärkt nordisk IFI- samordning - åtgärder för att öka den nordiska slagkraften i IFIs med betoning på verksamhet $\mathrm{i}$ Östersjöregionen och dess närområde}

De nordiska länderna har sedan länge ett jämförelsevis välutvecklat samarbete inom olika IFIs. I vissa institutioner följer detta av att de nordiska länderna - och numera även de baltiska - ingår i samma valkrets, vilket är fallet i Internationella valutafonden och Världsbanken liksom i en del regionala utvecklingsbanker. I andra fall har ett närmare samarbete utvecklats trots att länderna tillhör olika valkretsar eller grupperingar. Formerna för samarbetet framstår dock som alltför traditionsbundna med en överdriven respekt för den formella beslutsgången, vilket ofta reducerar det inflytande som kan utövas. Det finns anledning att överväga en förnyelse, främst för att bidra till ökat genomslag för nordiska synpunkter på institutionernas verksamhet men också för att tillgodose växande krav i de nordiska länderna på tydlighet och transparens i agerandet i olika internationella fora.

Föreliggande utredning ägnas åt hur insatserna via olika multilaterala organ i Östersjöregionen och dess närområde skall kunna effektiviseras. Därav följer att framställningen koncentreras till de viktigaste IFIs som är verksamma i denna region. Vilka institutioner det är fråga om har redovisats i inledningsavsnittet. Internationella valutafonden (IMF) är förvisso också en viktig IFI som är verksam i regionen, men institutionens allmänekonomiska övervakning och makrobetonade finansiering ligger utanför det projektorienterade område som rapporten är inriktad på. Nedanstående synpunkter på förstärkt IFI-samordning kan dock anses vara tillämpliga även på IMF. Dessutom är det oundvikligt att i genomgången inkludera EU-kommissionen, som inte är ett multilateralt organ i traditionell mening, men en synnerligen viktig aktör och finansiär i regionen. 


\subsection{Den nordiska IFI-samordningen idag - problem och brister}

Den traditionella nordiska - eller nordisk-baltiska - samordningen av synpunkter är till stor del inriktad på formella beslutstillfällen såsom exekutivstyrelsernas möten eller möten med IFIs guvernörer eller olika policyskapande kommittéer. Samordnade riktlinjer eller instruktioner till sådana möten är emellanåt nödvändiga. Som huvudsakligt instrument för att söka få genomslag för landgruppens/valkretsens synpunkter är de dock inte särskilt effektiva. De är dessutom onödigt arbetskrävande, eftersom betydande möda läggs ner på att inom gruppen förhandla om detaljformuleringar som i praktiken spelar begränsad roll. Svagheterna är dels att synpunkterna framförs vid en alltför sen tidpunkt, dels att arbetssättet blir mycket reaktivt genom att kommentarer genomgående lämnas på färdiga förslag från enskilda IFIs.

Ovanstående modell gäller i första hand för de båda Bretton Woodsinstitutionerna, d.v.s. IMF och Världsbanken samt icke-europeiska utvecklingsbanker. För andra IFIs som är verksamma i regionen och därmed av särskilt intresse i detta sammanhang - EBRD, EIB, CEB och NIB - är förhållandena annorlunda. I EBRD är de nordisk/baltiska länderna uppdelade på tre valkretsar med utsända direktörer. Ett kontinuerligt samråd sker mellan dem, men i praktiken agerar de efter riktlinjer från respektive huvudstäder. Betoningen på beredning av formella möten är dock ungefär densamma som i Världsbanken. EIB och CEB har en organisationsmodell som innebär tillresande representanter i direktörsstyrelsen, vilket skapar en annan typ av svårigheter. Särskilt i EIB, som volymmässigt är världens största IFIs, är det närmast omöjligt för den tillresande att ordentligt sätta sig in i den mångfald av ärenden som tas upp vid varje sammanträde. NIB slutligen är ett specialfall eftersom ägarkretsen överensstämmer med den nordisk/baltiska gruppen och diskussioner om bankens strategi och verksamhet kan föras direkt i bankens organ, antingen i den tillresande styrelsen eller mellan bankens guvernörer (ekono$\mathrm{mi} /$ finansministrarna). För institutioner med en bredare medlemskrets finns det behov att tänka igenom hur en grupp mindre eller medelstora länder skall utveckla ett mera strategiskt arbetssätt. Synpunkter på denna uppgift utvecklas i följande avsnitt.

\subsection{Behov av övergripande strategier}

De nordiska länderna har - med ett viktigt undantag - inte några genomarbetade strategier för sitt agerande i stora IFIs som EBRD, EIB och Världsbanken. Undantaget är Danmark som har utvecklat ett mycket ambitiöst strategiarbete vad gäller Världsbanken, i första hand avseende bankens verksamhet i utvecklingsländer. I Sverige har nyligen beslut 
tagits om en samlad strategi för det multilaterala utvecklingssamarbetet, vilken skall följas av detaljerade strategier för enskilda institutioner på utvecklingsområdet. I övrigt finns inga egentliga strategier utan agerandet baseras på diverse underlag alltifrån enskilda regeringsdokument, av vilka vissa framläggs i parlamenten, till uttalanden i samband med möten i IFIs. När det gäller IFIs som är speciellt aktiva i den region som utredningen är inriktad på förefaller bristen på genomarbetade underlag vara särskilt tydlig.

Strategier behövs först och främst som grund för en mera systematiskt och långsiktigt agerande. Externt tryck på att utforma strategier har dessutom uppkommit främst på biståndsområdet, exempelvis i OECDs utvecklingskommitté (DAC), men det är knappast någon vågad gissning att liknande påtryckningar kommer vad gäller annan IFI-verksamhet. Strategierna behöver inte vara så ambitiösa som det danska exemplet som består av strategidokument i kombination med detaljerade årliga handlingsplaner. Vidare förefaller det mest realistiskt att satsa på nationella strategier. Gemensamma nordiska eller nordisk/baltiska strategier vore ett tänkbart alternativ, men det skulle sannolikt kräva ett omfattande arbete och möjligen leda till onödigt utslätade dokument. Samordningen kan i stället ske via gemensamma policydokument i enskilda viktiga frågor, vilket berörs nedan.

Det finns inte endast ett externt tryck på att de nordiska ländernas agerande i multilaterala institutioner skall baseras på mera genomtänkta strategier. Parlamentsutskott och nationella revisionsorgan i de nordiska länderna har på senare tid fäst uppmärksamheten på avsaknaden av strategidokument. Det multilaterala strategiarbetet i Sverige är delvis ett resultat av kritiska synpunkter från riksdagens utrikesutskott. Krav på tydlighet och transparens i agerandet kan till betydande del tillgodoses med hjälp av övergripande riktlinjer som fastställts i enlighet med nationella beslutsförfaranden.

\subsection{Behov av förstärkt nationell koordinering}

Tydliga strategidokument för olika IFIs kan vara till väsentlig hjälp i ansträngningarna att få till stånd ett välkoordinerat uppträdande från olika ministerier eller myndigheter i respektive land. Det är dock inte tillfyllest - dessutom krävs ett närmare och kontinuerligt samråd mellan berörda ministerier. En uppenbar svaghet i de nordiska ländernas agerande i Östersjöfrågor är att dialogen mellan framför allt utrikesministerier å ena sidan och ekonomi/finansministerier å den andra är bristfällig. Något förenklat är läget vanligen det att utrikesministerierna ansvarar för regionala organ och Världsbanken, medan ekonomi/finansministerierna svarar för EBRD, EIB och NIB. Frekvensen av regelbundna kontakter varierar mellan länderna, men generellt sett är det uppenbart att samrådet är otill- 
räckligt. Situationen verkar vara något bättre i länder som Finland och Sverige där även ansvaret för Världsbanken är uppdelat mellan de båda ministerierna.

Denna situation medverkar till att utrikesministerierna inte riktigt inser IFIs strategiska betydelse för utvecklingen i Östersjöregionen och dess närområde samtidigt som ekonomi/finansministerierna sannolikt underskattar betydelsen av vissa regionala organs verksamhet. Därigenom bidrar denna kluvenhet till att de synergier som skulle kunna uppkomma mellan olika aktörer inte förverkligas. Ett ytterligare argument för en mera ambitiös nationell koordinering följer av att man från nordisk sida ofta kritiserar det otillfredsställande samrådet mellan olika ministerier i andra länder i Östersjöregionen, t.ex. Ryssland. En sådan kritik blir mera välgrundad om de nordiska länderna kan föregå med gott exempel.

\subsection{Behov av omläggning av beredningsarbetet gentemot IFIs}

Alternativet till att komma in relativt sent i beslutskedjan med synpunkter till styrelsemöten är att arbeta mera proaktivt med sekretariaten eller "staberna" i enskilda IFIs i betydligt tidigare skeden. En metod är att försöka påverka problemformuleringen genom att inkomma med ett gemensamt policydokument redan när diskussionen av en principfråga initieras. Norden/Baltikum har praktiserat detta med avsevärd framgång vid ett par tillfällen under senare år avseende diskussioner i Världsbanken om verksamhet i medelinkomstländer respektive konditionalitet. Förslaget innebär att hemmamyndigheterna skall lägga ner avsevärt mera resurser på den typen av genomarbetade underlagsdokument och samtidigt sänka ambitionerna beträffande löpande instruktionsgivning. Det skall ännu en gång understrykas att riktlinjer/instruktioner alltfort behövs i ett antal enskilda beslutsärenden; en ändring skulle enbart innebära en förändrad balans i hemmamyndigheternas arbete. En annan form för ambitiös samordning i globala IFIs som syftar till att stärka den egna medlemsgruppens roll är den som sker i EU-regi. Eftersom EUkoordineringen inte omfattar samtliga länder i den nordisk-baltiska gruppen tas den inte upp till närmare behandling här. Det bör dock noteras att fördjupad EU-samordning i multilaterala organ kan göra det svårare att driva specifika nordisk-baltiska initiativ.

I institutioner som EBRD och EIB där Norden har flera olika representanter kunde man trots detta på liknande sätt utforma gemensamma policydokument i centrala frågor som underlag för direktörernas agerande. Med sådana underlag på plats vore det dessutom naturligt att ge direktörerna stor frihet att ta kontakter med staben eller företrädare för andra länder, t.ex. för att utröna förutsättningarna för stöd till de nordiska synpunkterna. En sådan ökad flexibilitet bör ge bättre arbetsförutsättningar 
för de nordiska företrädarna samtidigt som det medverkar till att stärka vårt inflytande. För den sista kategorin - institutioner med enbart nordiskt/baltiskt eller nordiskt medlemskap - är det naturligt att beredningsarbetet sker inom de egna organen.

\subsection{Behov av ökat lateralt tänkande}

De nordiska länderna är fullvärdiga medlemmar i alla de IFIs som behandlas här, frånsett att Island och Norge står utanför EIB. En möjlighet som ofta förbises är att utnyttja den samlade kompetens som finns hos våra representanter i olika institutioner, vilka är verksamma i den aktuella regionen. Regelbundna, t.ex. årsvisa, möten mellan berörda direktörer skulle kunna bidra till att utveckla och förenhetliga det nordiska agerandet i olika fora. Det skulle också kunna vara en metod för att få bättre grepp om en betydelsefull fråga som behandlas närmare i det följande, nämligen den delikata avvägningen mellan samordning och konkurrens mellan IFIs. Regelbundna möten kan kompletteras med smidiga former för ett mera kontinuerligt samråd mellan direktörerna. Ett övergripande syfte med utvidgat interinstitutionellt samråd är att bidra till ett systemorienterat arbetssätt. Alla olika IFIs bildar ett multilateralt system som bör ses som en helhet. Därigenom skapas bättre förutsättningar för effektivt agerande samtidigt som risken för överlappning reduceras. 



\section{Grundläggande förutsättningar för additionella nordiska satsningar i anknytning till relevanta IFIs}

Utöver mera målinriktad samordning kan de nordiska länderna stärka sitt inflytande på IFIs verksamhet och få genomslag för sina prioriteringar genom att fördjupa det direkta samarbetet med dem. En tänkbar form är samnordiska initiativ som komplement till institutionernas egna insatser. Det är viktigt att understryka att det är fråga om att komplettera och inte att ersätta IFIs egen verksamhet. En grundförutsättning för sådana nordiska tilläggsinitiativ är också att de tillgodoser det grundläggande kravet på faktiskt mervärde, d.v.s. att en gemensam insats ger mera effekt än separata nationella insatser. Annorlunda uttryckt: om ett mervärde inte kan göras sannolikt, finns det knappast anledning att investera den ytterligare tid och de extra resurser som oundvikligen följer med en samordning mellan fem länder. Mervärdet kan följa av den samnordiska insatsen i sig eller framkomma som en katalytisk effekt, t.ex. genom att intressenter utanför Norden beslutar att också bidra till en viss verksamhet.

I en del fall är det relativt enkelt att visa att additionella insatser $i$ anknytning till IFIs är kostnadseffektiva. De stora miljösatsningarna i nordvästra Ryssland är ett exempel. Det kan noteras att ett organ som NEFCO för varje investering räknar ut vad det skulle kosta att åstadkomma samma miljönytta i Norden. Ofta är dock kostnadseffektivitet och mervärde svåra att mäta a priori. Av avgörande betydelse blir i stället att varje nordiskt land, innan ett nytt gemensamt projekt sätts i sjön, är övertygat om att det har goda förutsättningar att skapa det önskade mervärdet. Vilka komplikationer detta kan medföra med tanke på de nordiska ländernas olika prioriteringar i regionen behandlas närmare nedan.

\subsection{Den trilaterala intressegemenskapen}

Det räcker inte med nordisk enighet om additionella gemensamma initiativ i IFIs för att de skall kunna genomföras. I stället krävs en trilateral intressegemenskap som omfattar för det första de länder som berörs av sådana insatser, för det andra den eller de IFIs som samarbetet skall omfatta och för det tredje initiativtagarna, d.v.s. de nordiska länderna. 
På den första punkten krävs det givetvis ett ingående samråd med de länder som berörs och en tydlig prioritering från deras sida för att ett projekt skall föras vidare. Dessa prioriteringar är normalt välkända genom olika nationella strategier. I samband med diskussionerna om Nordliga dimensionen 2006 framlades exempelvis från rysk sida en lista på prioriterade projekt inom miljö- och transportområdena.

Samtidigt måste beaktas att läget förändrats i grunden sedan den inledande transitionsfasen. De internationella finansinstitutionerna är inte längre nödvändiga samarbetspartner utan utgör ett alternativ bland flera ("The Bank has developed from a partner of necessity to a partner of choice" som Världsbanken formulerat det). Samarbetet har därigenom blivit klart mera efterfrågestyrt och mera inriktat på utveckling av den privata sektorn. Den offentliga sektorns minskade roll i transitionsekonomierna samt återhållsamheten vad gäller offentlig skuldsättning har starkt bidragit till den förändrade inriktningen. EU-integrationen har för flertalet länder sannolikt varit den viktigaste faktorn för att driva på ett nödvändigt reformarbete, men ett antal "andra generationens" reformer återstår att realisera. Här kan IFIs spela en väsentlig kompletterande roll både med policyrådgivning och visst finansiellt stöd. Till det kommer att många projekt alltmer berör hela Östersjöregionen. Det gäller inte enbart miljöområdet där det gränsöverskridande samarbetet kanske kommit längst. De nordiska länderna måste givetvis anpassa eventuella additionella satsningar i samarbete med IFIs till dessa pågående förändringar.

Speciella komplikationer uppkommer dessutom om ambitionen är att uppnå ett geografiskt sett omfattande samarbete innefattande flertalet länder i regionen. Förutom att det blir allmänt krångligt att nå bred accept i en så stor grupp återkommer de svårigheter som följer av bristande engagemang i Östersjösamarbetet hos vissa länder. Hinder av mera administrativ karaktär, t.ex. svårigheter att kunna få till stånd en fungerande dialog med relevanta federala motparter i Ryssland eller oklarheter i ansvarsuppdelningen mellan central och regional nivå, kan också allvarligt försena eller t.o.m. omintetgöra projekt. Liknande problem kan uppkomma när det är fråga om utlåning till den sub-regionala nivån utan statliga garantier.

Den andra förutsättningen är att de internationella finansiella institutioner Norden vill samarbeta med är villiga att delta i additionella insatser/program. Normalt bör inte detta utgöra något problem. Frågan är snarare att förhandla fram de villkor för samarbetet som är godtagbara för parterna. Några IFIs, kanske särskilt Världsbanken, är dock engagerade i så många specialarrangemang, trustfonder etc. att man vill vara återhållsam med att engagera sig i nya liknande projekt. Varje IFI har därtill anledning att göra en prövning baserad på vilka aktiviteter som redan pågår i syfte att undvika dubbleringar. Det är med andra ord ingen självklarhet att en IFI villigt ställer upp på att hantera ett särfinansierat specialprogram i verksamheten. Samtidigt måste noteras att IFIs har ett brett 
produktutbud som med betydande flexibilitet kan anpassas till samarbetsländernas önskemål. De kompletterande nordiska insatserna kan dessutom vara relativt måttliga i finansiella termer för att t.ex. möjliggöra tekniskt eller analytiskt stöd via IFIs. Dessutom kan man förvänta sig att vissa mottagarländer själva betalar för en väsentlig del av angelägna satsningar (fee-for-service arrangements).

Den tredje förutsättningen gäller intresset hos de nordiska länderna själva att komplettera olika former av multilateralt stöd och därmed totalt sett stärka effekten av aktuella program i regionen. I förstone kan man tro att detta är den del av den trilaterala strukturen som är enklast att klara ut. Närområdespolitiken har varit en huvudpelare som medverkat till att ge nytt liv åt det nordiska samarbetet. Slutsatsen av ett stort antal diskussioner med olika nordiska företrädare under utredningsarbetets gång måste dock bli mera nyanserad. Den bild som alltjämt tecknas i högstämda middagstal av det gemensamma nordiska intresset att utveckla och stärka Östersjöregionen och dess närområde är inte längre helt rättvisande. Enigheten för 10-15 år sedan om vikten av att agera samfällt för att stödja utvecklingen mot demokrati och marknadsekonomi på andra sidan Östersjön har ersatts av varierande prioriteringar och intressen i de nordiska länderna.

De ökande meningsskillnaderna i Norden är till viss del ett naturligt resultat av de stora förändringar som inträffat. Det faktum att tillgängliga nationella budgetmedel för satsningar i närområdet reducerats i takt med att ett biståndssamarbete ersatts av ett grannlandssamarbete mellan jämbördiga parter har givetvis påverkat synen på vad som kan och bör göras. Detsamma följer av en annan, ännu viktigare omvälvning, nämligen att ett flertal transitionsländer blivit fullvärdiga medlemmar i EU med åtföljande utökade finansieringsmöjligheter. Norge och Island bidrar till denna ökade finansiering via EEAs speciella mekanism.

Ett annat tecken på tilltagande divergerande intressen i Norden är att vissa gemensamma satsningar inte gått att genomföra fullt ut såsom kapitalförstärkning i NEFCO eller användning av återflöde från EBRD (från Baltiska investeringsprogrammet) för förstärkning av Nordliga dimensionens miljöpartnerskap. Pågående avveckling av Nordiska utvecklingsfonden kan ses som ytterligare ett exempel på otillräckligt intresse för gemensamma nordiska lösningar, även om den avser en verksamhet som rör helt andra former av finansiering.

Om man skall försöka att i förenklad form återge de nyansskillnader som finns mellan de nordiska länderna när det gäller synen på ekonomiskt och annat samarbete i regionen förefaller Danmark vara det land som tydligast anvisar samverkan inom EU:s ram eller rent bilaterala insatser som prefererade lösningar, medan Finland fäster särskild vikt vid utvecklingen av Nordliga Dimensionen, d.v.s. samarbetet med Ryssland. Island betonar Östersjösamarbetets fortsatta utveckling men har förståeligt nog andra geografiska prioriteringar. Norge prioriterar starkt utveck- 
lingen av de allra nordligaste delarna av regionen. Sverige har haft en något vag preferens för Östersjösamarbetet i sig med en uttalad institutionell betoning av Östersjöstaternas råd. Den svenska regering som tillträdde 2006 framhåller också samarbetet i hela Östersjöregionen i sig, men med en mera öppen inställning till de institutionella lösningarna. Prioriteringen av sakområden är något mera samstämmig i Norden, men även här finns skillnader.

Trots dessa olika uppfattningar bör det vara möjligt att på enskilda områden finna underlag för specifika nordiska initiativ i samarbete med IFIs. Erfarenheterna av de gemensamma satsningar som gjorts under åren såsom det Baltiska investeringsprogrammet i EBRD/NIB/Nopef eller initiativet till ett brett IFI-samråd som banade väg för miljöpartnerskapet är i huvudsak mycket goda. Pågående förändring av finansinstitutionernas verksamhet med ökad betoning av subregionala eller lokala projekt, särskilt inom privat sektor, skapar i sig nya möjligheter för samarbete. Konkreta nordiska initiativ kan dessutom medverka till att påskynda förändringsarbetet inom IFIs. Därför finns det anledning att lägga ner viss kraft på att söka utveckla de idéer som presenteras inom ramen för denna utredning och uppföljningen av den. Återigen bör understrykas att det i de enskilda fallen inte behöver röra sig om så stora tilläggsresurser, finansiellt eller personellt. Det gäller i stället att finna de områden där det går att skapa ett egentligt mervärde. Dessutom måste den "nordiska nyttan" av sådana satsningar kunna visas antingen på makroplanet i form av snabbare ekonomisk tillväxt och ökad handel i hela regionen eller mikrobetonade effekter som framsteg vad gäller viss typ av forskning och utveckling eller underlättande av praktiskt företagssamarbete.

Skulle det å andra sidan visa sig omöjligt att nå enighet om nya samnordiska satsningar där utväxlingen via IFIs utnyttjas, finns det skäl att något tona ner den nordiska retoriken kring att arbeta för att stärka Östersjöregionen och dess närområde. Om inte de nordiska länderna kan kraftsamla och på olika sätt försöka driva på den ekonomiska integrationsprocessen finns det knappast någon annan som tar på sig uppgiften. Östersjöregionen kännetecknas inte endast av att den är heterogen vad gäller ekonomisk utvecklingsgrad utan också, vilket är betydligt allvarligare, att engagemanget för att satsa på regionen är så varierande. Två av de största länderna - Tyskland och Polen - visar, i alla fall från federalt håll, ett tämligen avmätt intresse. I uttalanden från delstatsparlament i norra Tyskland framhålls ofta behovet av att säkra ett mera aktivt tyskt deltagande i Östersjösamarbetet på nationell nivå. Det otillräckliga engagemanget sammanhänger naturligtvis med att Tysklands och Polens ekonomiska centra är orienterade mot andra delar av Europa. Ryssland å sin sida är ofta intresserat och inriktat på praktiska resultat, men intresset kan variera starkt från område till område. Bevarande av regionens position som en av de mest konkurrenskraftiga och utvecklingsbara i Europa förutsätter - bland många andra ting - att några länder tar på sig rollen att agera pådrivare. 


\subsection{Interaktionen mellan regionala fora och IFIs}

Det välutvecklade mellanstatliga samarbetet i Östersjöområdet och näraliggande länder rymmer i sig möjligheter för konstruktiva kopplingar mellan å ena sidan regional sakkunskap och å den andra de multilaterala institutionernas finansiella styrka och specialkompetens. Principiellt borde de regionala organen ha goda förutsättningar att agera som projektidentifierare och även - i mån av budgetresurser - svara för bidrag till en första beredning innan IFIs kontaktas. Hittills har dock sådana kombinationsmöjligheter inte utnyttjats särskilt effektivt. I nordiska och nationella program lyfts ofta regionala fora och processer fram, men länken till ett bredare multilateralt samarbete ägnas inte tillräcklig uppmärksamhet. Med risk för överdriven generalisering måste också sägas att de regionala organen själva sällan har lyckats att etablera ett samråd/samarbete med IFIs som skulle kunna generera ett önskvärt flöde av konkreta projektförslag. Sådana förslag skulle som sagt i nästa steg kunna finansieras med multilaterala medel eller bli föremål för olika former av samfinansiering.

En återkommande förklaring till de klena resultaten är att de regionala organen är programfokuserade snarare än projektinriktade. Denna allmänna ursäkt håller inte för en närmare granskning. Det är i stället avsaknaden av en fungerande dialog mellan flertalet regionala råd och IFIs som är huvudorsaken. I en sådan dialog skulle parterna med gemensamma ansträngningar kunna omsätta programidéer till konkreta projektförslag som i sin tur kunde få finansiering från IFIs och andra bidragsgivare.

Nordiska ministerrådet (NMR) som regeringarnas övergripande samarbetsorgan borde ha goda förutsättningar att på de nordiska ländernas vägnar fungera som initiativtagare till eller katalysator för olika multilaterala insatser i Östersjöregionen eller dess närområde. I de många policydokument som utformats - t.ex. NMRs allmänna Rysslands-program 2006-08, riktlinjer för samarbetet med Nordvästryssland 2006-08, riktlinjer för samarbete med Estland, Lettland och Litauen 2006-08 eller arktiskt samarbetsprogram 2006-08 - ges också ett allmänt intryck av att samarbetet med multilaterala organ, inklusive IFIs, är en viktig uppgift. Det hänvisas i Rysslandsprogrammet till att NMR är öppet för nya politiska initiativ och berett till ett flerpartssamarbete mellan Norden, de baltiska länderna och deras grannar Ryssland och Vitryssland i gränsöverskridande initiativ. Vidare sägs att "i detta samarbete kan också andra organisationer och EU:s nya finansieringsinstrument inlemmas”. Formuleringarna återspeglar den allmänna ambitionen att samnordiska projekt skall ge ett mervärde och dessutom bidra till en bättre samordning med andra insatser.

I praktiken har dock NMRs roll som initiativtagare till eller katalysator för multilaterala insatser varit milt sagt blygsam. Detta gäller även gentemot de nordiska finansinstitutionerna i Helsingfors (främst NIB, men delvis också NEFCO och Nopef). Det traditionella försvaret från 
t.ex. ministerrådets sekretariat på sistnämnda punkt är att det faller på ansvarigt ministerråd att övervaka de nordiska institutionernas verksamhet och se till att de överordnade riktlinjerna för samarbetet följs. Om inte t.ex. finans/ekonomi- eller miljöministrarna aktivt verkar för att nordiska institutioner noga följer uppställda program och riktlinjer har samarbetsministrarna eller sekretariatet små möjligheter att agera.

Den ursprungliga politiska ambitionen att göra NIB till ett viktigt "samnordiskt redskap" har sällan lett till tydliga initiativ från NMR, oavsett ministerrådets sammansättning. Det förhållandet att NIB sedan ett par år har en medlemskrets som går utöver den nordiska gruppen och dessutom ett eget guvernörsråd har förändrat uppgiften, men har knappast gjort den enklare. Det är dessutom en offentlig hemlighet att det löpande samarbetet mellan ministerrådets sekretariat i Köpenhamn och de nordiska finansinstitutionerna i Helsingfors inte fungerar helt tillfredsställande Man kan spekulera i varför samarbetet mellan NMRs sekretariat och NIB inte kunnat bli en interaktion som åtminstone påminner om det delvis jämförbara samarbetet mellan EU-kommissionen och Europeiska investeringsbanken. Ett av flera skäl är säkert den brist på effektivt samråd mellan de olika nationella huvudmännen som berörts ovan.

Avsaknaden av helhetssyn medverkar till att de multilaterala finansinstitutionernas strategiska roll för samarbetet i regionen alltför ofta reduceras till några allmänna fraser i de nordiska programmen och riktlinjerna. I den mån IFIs direkt nämns är det vanligen i form av hänvisningar till de nordiska institutionerna samt att deras och ministerrådets övriga verksamhet koordineras genom samråd och årsrapporter. Ett positivt undantag är den utförliga strategin "Hållbar utveckling - En ny kurs för Norden” avseende perioden 2005-08 som innehåller konkreta synpunkter på IFIs verksamhet. I olika strategiers diskussion kring tänkbara instrument för att genomföra önskat samarbete finns dock normalt inte någon tydlig koppling till synergier som kompetensen och de finansiella resurserna hos nordiska eller andra IFIs kan bidra till.

Denna kritiska syn på NMRs - och sekretariatets - insatser för att bana väg för samarbete med IFIs blir något mera nyanserad när man också beaktar aktiviteter i de olika specialorgan som sorterar under ministerrådet. På ett strategiskt viktigt område som forskning/utveckling och innovationer pågår i NordForsk, Nordisk Energiforskning och Nordisk InnovationsCenter olika verksamheter som kan skapa underlag för multilaterala insatser på bl.a. riskkapitalområdet.

Inte heller Östersjöstaternas råd (CBSS) har kommit att få någon större roll som förmedlande instans mellan regionalt samarbete och multilateral verksamhet. CBSS är ett övergripande forum för mellanstatligt samarbete i Östersjöområdet. Utredningens sektorsvisa genomgång har allmänt gett vid handen att förvånansvärt många av de samarbetsinitiativ som faller under CBSS har utvecklats svagt. En närmare granskning av CBSS' arbete på just de ekonomiska och finansiella områdena leder till slutsat- 
sen att det kännetecknas av en brist på egentlig substans. Undantag är vissa värdefulla punktinsatser avseende avveckling av hinder för handel och investeringar. Dessa insatser har ofta initierats från näringslivshåll. En viktig förklaring till CBSS' alltmer begränsade roll är självfallet att initiativet till gränsöverskridande samarbete i stor utsträckning övergått från regeringarna till andra aktörer.

Man kan ställa frågan, vilket också sker i vissa medlemsländer, om det är motiverat att behålla en särskild grupp för brett ekonomiskt samarbete (WGEC), när denna grupp trots upprepade ansträngningar inte kan fylla dagordningen med flera konkreta samarbetsförslag. Det ligger dock utanför denna utrednings uppgift att dra bestämda slutsatser på denna punkt. Här räcker det med att konstatera att upprepade uttalanden från ministermöten i CBSS om vikten av att interagera med IFIs i syfte att stärka deras roll i det regionala samarbetet inte lett till mycket mer än enstaka gemensamma informationsinsatser. WGEC's kontakter med de multilaterala finansinstitutionerna verkar sakna egentlig betydelse för konkret projektverksamhet.

Vid CBSS' utrikesministermöte i Malmö i juni 2007 enades man om en reformering av rådet i syfte att inrikta verksamheten på vissa prioriterade områden. Kapaciteten att utveckla viktiga regionala projekt - inklusive finansieringen av dem - skall stärkas, vilket i och för sig är välkommet. Som vanligt bortses dock från IFIs potentiella roll i sammanhanget. Föreställningen att CBSS eller dess olika organ skall kunna klarlägga finansieringen av större projekt framstår milt sagt som orealistisk.

Barentsrådet (BEAC), vars styrka bl.a. ligger i en mera handfast förankring i regionalt, subregionalt eller lokalt samarbete, har däremot ägnat sig åt att söka utveckla verksamhet som utnyttjar de multilaterala institutionernas tekniska och finansiella resurser. Ett framstående exempel på detta är samarbetet med NEFCO när det gäller att identifiera och åtgärda miljömässiga s.k. hot spots i den ryska delen av Barentsregionen. Även på transport- och energiområdena pågår aktiviteter inom BEACs ram som har genererat eller kan komma att generera olika former av extern finansiering. Rådet har även i övrigt en omfattande verksamhet som spänner över flertalet samarbetsområden som är vitala för Barentsregionen. Under det nuvarande finländska ordförandeskapet i BEAC prioriteras bl.a. gränsöverskridande ekonomiskt samarbete i regionen. Som helhet kan BEAC ses som ett samarbetsorgan som aktivt försöker verka för en sammankoppling av regionala satsningar och multilateral kompetens/finansiering.

Arktiska rådet $(A C)$ har en bred inriktning på hållbar utvecklings samtliga tre dimensioner - den miljörelaterade, den ekonomiska och den sociala. Hittills har betoningen legat på övergripande miljöfrågor, bl.a. genom sammanställning av ett handlingsprogram på grundval av en omfattande klimatrapport (Arctic Climate Impact Assessment). Ordförandeländerna Norge, Danmark och Sverige har lagt fram gemensamma mål för verksamheten under perioden 2006-12. Däri ingår att genomföra re- 
kommendationerna i nämnda handlingsplan. Efter hand som samarbetet utvecklas bör det finnas anledning att höja ambitionerna när det gäller satsningar på konkreta projekt, vilket skulle underlättas av en samverkan med multilaterala finansorgan. Valet av NEFCO som utvecklare av ett nytt instrument för projektstöd inom ACs ram kan ses som ett steg i denna riktning. Det faktum att en sådan fond nu etablerats kan förhoppningsvis medverka till framsteg i arbetet på att lösa finansieringsfrågorna i AC.

Bland informella regionala samarbetsfora är de årliga konferenserna mellan Östersjöländernas finansministrar av speciellt intresse för det ekonomiska samarbetet i regionen. Konferenserna, som har ägt rum sedan 1996, har vid sidan av värdefullt informationsutbyte i växande grad kommit att ägnas åt diskussioner kring konkreta samarbetsmöjligheter. Som närmare redovisas under avsnitt 5.5. har de senaste årens möten särskilt uppmärksammat möjligheterna till samarbete inom den finansiella sektorn. Eftersom ministermötena numera blir föremål för omfattande förberedelser på tjänstemannanivå borde det i och för sig vara möjligt att inom denna ram utveckla samarbetsidéer av mera omfattande slag som även kunde inkludera samarbete med IFIs. En sådan sammankoppling underlättas av att finansministerierna i de aktuella länderna normalt är ansvariga för relevanta IFIs och därmed känner deras verksamhet mycket väl. Erfarenheterna tyder dock på att det är svårt att få till stånd en gemensam mobilisering. Några länder ställer sig skeptiska till regionala försök att påskynda integrationen utöver vad som följer av överenskommelser inom EUs ram. Det kan möjligen ses som ytterligare en bekräftelse på att Östersjösamarbetet inte är prioriterat i samtliga berörda länder. 


\section{Tänkbara samarbetsområden med IFI-involvering}

Syftet med detta avsnitt är att gå igenom olika samarbetsområden där framtida gemensamma insatser från de nordiska länderna/regeringarna kan kombineras med IFI-medverkan. Det skall ånyo understrykas att avsikten inte är att komma med synpunkter på det viktiga samarbete som redan pågår - och som kan förväntas fortsätta - mellan ett antal IFIs å ena sidan och nationella nordiska biståndsmyndigheter å den andra när det gäller t.ex. projekt på miljö- eller energieffektiviseringsområdena. Inte heller är avsikten att här komma med konkreta projektförslag. Tanken är i stället att göra en allmän bedömning av olika väsentliga samarbetsområden och ange var additionella nordiska insatser vore speciellt lämpliga för att främja en regional ansats samt - tvärtom - var sådana insatser förefaller mindre motiverade.

\subsection{Miljöområdet}

Miljösektorn är ett av de områden där det finns ett välutvecklat samarbete mellan nordiska (och andra) länder och IFIs samt en etablerad struktur för denna samverkan, i första hand i form av Nordliga dimensionens miljöpartnerskap, NDEP. Partnerskapet, som är involverat i ett betydande antal prioriterade projekt i nordvästra Ryssland, beskrivs närmare under avsnitt 7.3. En prioriterad uppgift för Norden bör vara att, tillsammans med partnerländerna i ND, bygga vidare på denna struktur. För den närmaste framtiden är det särskilt angeläget att medverka dels till högre tempo i genomförandet av projekt på kärnsäkerhetsområdet, dels till att stödfondens fönster för allmänna miljöprojekt får erforderliga resurser. Ett brett deltagande från de presumtiva givarna i pågående påfyllnad torde förutsätta en hög nordisk profil.

Vid sidan av NDEP finns det dock ett antal andra möjligheter att öka samverkan med IFIs på miljöområdet. Ett första exempel är att IFIs, d.v.s. NEFCO, har engagerats i Helsingforskommissionens (HELCOM) arbete på ett utveckla en samlad handlingsplan för Östersjön, Baltic Sea Action Plan. Denna handlingsplan, som skall antas under 2007, kan väntas få stor betydelse för det framtida miljöarbetet i regionen. Vid ett högnivåmöte med företrädare för miljö- och jordbruksministerierna i CBSSländerna i april 2007 uttalades stöd för arbetet med handlingsplanen. När det gäller IFIs roll kunde mötet dock inte komma längre än att uppmuntra relevanta institutioner att intensifiera finansieringen av miljöförbättrande 
åtgärder i regionen. Formuleringen reflekterar ännu en gång den passiva eller överdrivet respektfulla - hållning gentemot IFIs som kritiserats ovan.

Det förtjänar vidare att påpekas att stora förhoppningar även knöts till nätverket Baltic 21 när en handlingsplan för hållbar utveckling i regionen godkändes 1998. Baltic 21 är en del av samarbetet inom CBSS och har IFIs bland medlemmarna, Däremot deltar IFIs beklagligtvis inte i Baltic 21:s löpande mötesverksamhet, trots att de är medlemmar. Allmänt sett har Baltic 21 knappast fått den tänkta rollen som ett centralt instrument för att driva på arbetet att främja hållbar utveckling. Det bör dock vara ett nordiskt intresse att fortsatt aktivt stödja nätverket och försöka medverka till internationell finansiering av projektverksamheten. Nyligen inleddes arbetet med fyra strategiska projekt: bioenergi, innovationer för hållbar utveckling, utbildning för hållbar utveckling samt balanserad utveckling land/stad. De nordiska länderna kunde utnyttja sina IFI-kontakter för att öka möjligheterna för stöd till projekten.

Den verksamhet som pågår inom BEAC och AC är ett annat exempel på regionala miljösatsningar som skulle kunna utgöra underlag för ett utvidgat samarbete med individuella IFIs. Finansinstitutionerna har dessutom medverkat i samordningen av projekt som inkluderat andra mellanstatliga organ, nationella myndigheter och olika frivillig-organisationer. På detta sätt fyller IFIs en viktig funktion i ansträngningarna att bygga konsensus kring prioriteringar, identifiera projekt och säkra erforderlig kapacitet för genomförande.

Intensifierat internationellt samarbete är vidare en förutsättning för mera effektiva insatser mot klimatförändringar. Världsbanken upprättade redan 1999 en prototypfond för att bana väg för specifika klimatprojekt, Prototype Carbon Fund. I takt med att klimatfrågorna fått växande betydelse har ett antal tilläggsfonder skapats i banken med en gemensam facilitet som ett "paraply". Fonderna har medverkat till att attrahera privata och offentliga medel till projekt som minskar utsläppen av växthusgaser. EBRD och EIB har gemensamt upprättat en multilateral fond för handel med utsläppsrätter som är kopplad till miljöprojekt i främst EBRDs verksamhetsländer, Multilateral Carbon Credit Fund. Länder och företag kan förvärva sådana rätter från projekt som leder till minskade utsläpp av växthusgaser. Fonden, som inledde sin verksamhet i december 2006, har erhållit bidrag från ett par nordiska länder. Världsbanken och EIB har i mars 2007 etablerat en liknande Carbon Fund for Europe med bland annat norskt deltagande. En investeringsfacilitet, Testing Ground Facility, har även etablerats för klimatprojekt i Östersjöregionen på grundval av ett beslut inom det regionala energisamarbetet BASREC (jfr nedan under 5.4.). Denna facilitet, som är inriktad på projekt i Baltikum, Ryssland och Ukraina, handhas av NEFCO. Förutom de fem nordiska länderna har Tyskland och ett antal privata företag investerat i denna mekanism för gemensamt genomförande. 
En annan väsentlig aktör på miljöområdet som IFIs arbetar med är Global Environment Facility, GEF. GEF är en fristående finansiell organisation som ger gåvostöd till framför allt u-länder för projekt som rör hantering av globala miljöproblem. På övergripande nivå styrs projektverksamheten av FNs miljöprogram, FNs utvecklingsprogram och Världsbanken. GEF verkar också i Östersjöregionen och EBRD tillhör de IFIs som utsetts till verkställande organ. Även nordiska institutioner som NEFCO medverkar i flera GEF-finansierade projekt. I framtiden verkar det finnas goda möjligheter att - med ledning av mottagarlandets prioriteringar - finna nya projekt i regionen som delfinansieras av GEF och som samtidigt engagerar olika IFIs. En sådan verksamhet har redan initierats vad gäller identifiering av projekt i Arktis med Ryssland som en huvudfinansiär vid sidan av GEF.

Samverkan på miljöområdet mellan de fem europabaserade IFIs som är verksamma i regionen (CEB, EBRD, EIB, NEFCO och NIB) har gett resultat även i annan form. Under 2006 enades de fem institutionerna om en serie miljöprinciper (European Principles for the Environment) i syfte att bidra till ökad harmonisering i samband med projektfinansiering. Principerna bygger på de regler som följer av fördraget och EUs sekundärlagstiftning. Syftet är främja harmonisering samt att förmå andra finansiärer att verka efter samma principer, exempelvis genom att ansluta sig till principdeklarationen. En gemensam arbetsgrupp har också bildats för att följa upp överenskommelsen.

De nordiska länderna bör dessutom fortsatt pröva i vilken utsträckning det gemensamma miljöfinansieringsbolaget NEFCO kan utnyttjas för ytterligare riktade miljöinsatser i regionen utöver de redan existerande faciliteterna som miljöutvecklingsfonden och Testing Ground Facility för gemensamt genomförande av klimatprojekt. Studier pågår redan av handelssystem för utsläppsrätter avseende kväve och fosfor. Nya eller utvidgade arrangemang förutsätter att ägarna är beredda att tillföra mera finansiella resurser till bolaget.

\subsection{Transporter}

Transportsektorn framstår som en lämplig kandidat för utökat regionalt samarbete med IFI-koppling. Idén om att skapa ett separat Östersjöforum för transportfrågor (Baltic Sea Transport Forum), som lanserades i en nordisk utredning 2004, kan dock inte längre anses ha någon aktualitet ${ }^{2}$. I stället bör en koppling till existerande institutionella ramverk eftersträvas. Finland har under sitt senaste EU-ordförandeskap framgångsrikt drivit att förslaget om Nordliga dimensionens partnerskap för transport och logis-

\footnotetext{
${ }^{2}$ The Future of Transport Sector Cooperation in the Baltic Sea Region. A Proposal for Institutional Framework and Substance of Baltic Sea Transport Policy on the Eve of EU Enlargement (ANP 2004:747).
} 
tik (NDTLP) skall bli föremål för fortsatt granskning. Initiativet torde i första hand få betydelse för sådana kompletterande infrastrukturprojekt, vid sidan av de stora transeuropeiska nätverken (TEN-Ts), som kan bidra till att stärka den regionala konkurrenskraften. I en utredning som utförts på uppdrag av NIB anges 20 sådana transportprojekt med betydande regionala återverkningar. Partnerskapet skulle göra det möjligt för samtliga länder i Östersjöregionen, inklusive nordiska icke-EU-medlemmar, att delta fullt ut i ett fördjupat samarbete.

En satsning på ett nytt partnerskap skulle också ligga i linje med handlingsprogrammet för nordiskt samarbete på transportområdet 2004-08. I detta program anges att samarbetet syftar till "att påverka EU:s transportpolitiska inriktning utifrån den nordliga dimensionen”. Samarbetet fokuseras kring fyra områden: Hållbar mobilitet, Östersjön, intelligenta transportsystem och trafiksäkerhet. Ett nytt partnerskap skulle också kunna utnyttja den kunskap som vunnits i olika subregionala projekt som också kan ses som komplement till TEN-Ts. Ett utmärkt exempel är Baltic Gateway som omfattat ett fyrtiotal partners från sju länder och som syftat till att utveckla ett övergripande system av högkvalitativa transporter och transportrelaterade tjänster i södra Östersjöområdet.

I det ursprungliga konceptet för NDTLP har lagts vikt vid att från början engagera relevanta IFIs i projektet, vilket torde vara en förutsättning för framgång. Den beredningsmetod som anvisas i ND-dokumenten från november 2006 är emellertid att ND Senior Officials skall vara ansvariga för granskningen av NDTLP tillsammans med experter och företrädare för IFIs. Detta tillvägagångssätt är möjligen politiskt nödvändigt, men det kan starkt ifrågasättas om det blir särskilt effektivt. De gynnsamma erfarenheterna av NDEP visar att det är av avgörande betydelse att de viktigaste IFIs redan från starten fungerar som "motorer" i arbetet. Därmed bör de också ges stort inflytande på partnerskapets uppbyggnad och organisation. Vidare är det väsentligt att den sakmässiga kompetens och objektivitet som IFIs kan stå för får genomslag på transportområdet där lokaliseringsfrågorna i sig får en annan tyngd än i partnerskapet på miljöområdet. Mot denna bakgrund är det positivt att NIB aktivt engagerat sig i det förberedande arbetet. Den långtgående koordinering som behövs för att genomföra gränsöverskridande transportprojekt talar slutligen för att även EU-kommissionen ges en framträdande roll i ett nytt partnerskap.

Ett annat skäl till att ämbetsmannagruppens roll bör kunna begränsas är att det på transportområdet knappast finns behov av mellanstatliga diskussioner om tilläggsfinansiering på benefika villkor. Till skillnad från NDEP behöver ett transportpartnerskap inte en stor stödfond eller liknande mekanism för kompletterande bilateral gåvofinansiering.

Gränsöverskridande transportprojekt ställer särskilt höga krav på koordinering mellan de olika nationella aktörer som svarar för implementeringen av projekten. IFIs kan här lämna viktiga bidrag till den nödvändiga samordningen tillsammans med EU-kommissionen. Erfarenheterna av 
arbetet med TEN-Ts under det senaste decenniet är nedslående i den meningen att flertalet projekt framskrider i betydligt långsammare takt än väntat. Det finns ett antal skäl till detta såsom överambitiösa planer, eskalerande kostnader, divergerande kommersiella och politiska intressen samt - kanske främst - otillräcklig och okoordinerad finansiering. Ett par omfattande översyner har gjorts av hela TEN-T-programmet för att åstadkomma tydligare prioriteringar.

Finansieringsmässigt har omfattningen av angelägna investeringar inom transportområdet påverkats av budgetrestriktioner i medlemsstaterna, lågt deltagande från den privata sidan och relativt små gemensamma EU-resurser. Det förhållandet att medel från nationella budgetar dominerat har gjort det svårt att hävda transnationella intressen. Ansträngningar görs nu för att förbättra styrningen av projekten, höja tillgången till EUresurser, bl.a. genom införande av ett nytt garantiinstrument, och främja privat medverkan. Alla de IFIs som primärt berörs i denna studie (EBRD, EIB, NIB och Världsbanken) har förutsättningar att bistå med kvalificerad teknisk assistans när det gäller att värdera och utforma innovativa finansieringslösningar, inklusive olika varianter av samarbete/samfinansiering med privat sektor.

Som konstaterats i flera utredningar ${ }^{3}$ är det en komplikation för utvecklingen av transportnäten att stora länder som Tyskland och Polen inte ser Östersjöregionen som ett prioriterat investeringsområde. De nordiska länderna - möjligen i samarbete med de baltiska - måste därför med kraft driva gemensamma regionala prioriteringar inom ramen för den bredare europeiska diskussionen om TEN-Ts och paneuropeiska transportkorridorer. En sådan profilering behövs även när det gäller projekt som i första hand är inomnordiska. Tillfälle till detta ges kanske främst i diskussioner inom EUs ram, inklusive EIB. Konceptet Motorways of the Seas är ett prioriterat projekt med stor regional betydelse där Norden - antingen i ett NDTLP eller i annan form - borde medverka till att det arbete som redan utförts mellan länderna kring Östersjön vidareutvecklas. Projekt för ökad sjösäkerhet i Östersjön är en annan prioritet som förutsätter fördjupad regional samverkan.

De transportprojekt som bör lyftas fram avser såväl länkar inom Östersjöregionen som förbindelser till närområdets länder, t.ex. Ukraina. Inom EU har en högnivågrupp nyligen identifierat de viktigaste transportlänkarna till grannländerna. Kommissionen har dessutom i ett meddelande från januari 2007 angett riktlinjer för integrering av transportsystemen i EU och grannländerna. I dessa riktlinjer prioriteras tre transportlänkar som direkt berör en utvidgad Östersjöregion (Motorways of the Seas, Northern axis, Central axis). I detta sammanhang är det också angeläget att beakta de konkreta förslag som presenteras av länder utanför EU, vilket bl.a. sker i transportdialogen med Ryssland. I den ryska listan över

\footnotetext{
${ }^{3}$ Intelligent Transport and Infrastructure in the Baltic Sea Region - An Innovative Key to Future Growth and Prosperity, Report from the Baltic Development Forum Round Table, October 2005.
} 
viktiga ND-projekt framhålls planerna på Barents Link som syftar till att utveckla godstrafiken på järnväg. Länken, som ingår i Barents särskilda transportområde, sträcker sig från Narvik i Norge via Sverige och Finland till slutstationen Perm i Ryssland.

\subsection{Forskning/utveckling och innovation}

\subsubsection{Gemensamma riskkapitalsatsningar med IFIs}

De multilaterala institutionernas verksamhet för att främja initiativ på forsknings- och innovationsområdet gäller projekt av skilda slag från stöd till småföretag i framtidsbranscher till storskaliga satsningar av gränsöverskridande karaktär. Av särskild strategisk betydelse är att medverka till att tillgodose ett företags resursbehov under ett uppbyggnadsskede alltifrån såddfinansiering till expansionsfasen. Ett flertal IFIs är verksamma på detta område - EBRD, EIB/EIF ofta i samarbete med EUkommissionen, Världsbanken via IFC samt NEFCO. Verksamheten sker i form av investeringar i individuella projekt eller i fonder ("fund of funds”). Med tanke på de relativt outvecklade riskkapitalmarknaderna i transitionsländerna - men i viss mening också i Norden - bör detta område ses som en angelägen prioritet. Internationella studier, exempelvis EBRDs och Världsbankens gemensamma Business Environment and Enterprise Performance Survey, visar att tillgången till finansiering är ett stort problem för privatsektorutvecklingen i transitionsländer. Detta gäller särskilt för små och medelstora företag i såväl start- som expansionsfasen. Ännu mera uttalade är svårigheterna för s.k. mikroentreprenörer, vilkas projekt slentrianmässigt betraktas som "non-bankable". ${ }^{4}$

Nordisk InnovationsCenter (NICe) har på uppdrag av NMR nyligen utrett förutsättningarna att skapa en gemensam nordisk - eller nordisk/baltisk - investeringsfond (NIF). Det är fråga om en venture capital-fond som investerar i små och medelstora företag via privata riskkapitalfonder, d.v.s. en fond i fond-lösning. NIF skulle utgöra ett komplement till liknande offentligägda nationella fonder, som ofta arbetar med relativt strikta begränsningar till hemlandet och under skilda regelsystem. En ny fond skulle därmed bidra till en gemensam riskkapitalmarknad. En utgångspunkt har vidare varit att granska möjligheterna att involvera NIB i projektet.

Den aktuella utredningen ${ }^{5}$ betonar starkt önskvärdheten av att skapa en nordisk marknad och ägnar stor uppmärksamhet åt de hinder som finns för nationella aktörer att engagera sig i gränsöverskridande projekt. Däremot görs inte en ordentlig behovsanalys. I synnerhet granskas inte de

\footnotetext{
${ }^{4}$ Se t.ex. Sylvie K. Bossoutrot: Microfinance in Russia - Broadening Access to Finance for Micro and Small Entrepreneurs, World Bank Working Paper No.67, 2005.

${ }^{5}$ Nordic Investment Fund, Promoting a common Nordic venture capital market, NICe, november 2006.
} 
svagheter som kännetecknar venture capital-segmentet av riskkapitalbranschen i Norden och som sannolikt är det viktigaste argumentet för de nordiska regeringarna att överväga att upprätta en gemensam fond i samarbete med en IFI. De internationella bedömningar som gjorts pekar på att nya företag i Norden har relativt lätt att ordna finansiering i initialfasen, men att situationen blir klart mera problematisk när företagen skall expandera. Få fonder i Norden inom det aktuella segmentet har tillräckliga finansiella resurser för att förverkliga hela kedjan av värdeskapande (the full value creation chain) för de bolag de investerat i. För bolagen betyder detta att de har svårt att nå fram till ett stadium med en marknadsposition som kan ge uthållighet. Alternativet, som ofta väljs, blir då att sälja bolaget redan i expansionsfasen till utländska intressenter.

NICes utredning utmynnar i förslag om att de nordiska länderna skapar en NIF. Förutom att finansiera uppbyggnad och expansion av små och medelstora företag via privata fonder förutses NIF spela en strategisk roll som främjare av "best practices" i de aktuella länderna. Dessutom rekommenderas att NIF upprättas under NIB eftersom fondens syfte överensstämmer med bankens allmänna mål samtidigt som det inte är önskvärt att öka antalet institutioner. Kapitalbehovet för NIF anges till $€$ 300-750 miljoner beroende på det detaljerade investeringsmandatet. Till denna kapitalbas skall, förutom NIB, andra offentliga eller privata investerare kunna bidra, inklusive finansiella institutioner i Norden.

Förslaget förefaller i sig vara värt att seriöst övervägas, även om en mera djupgående prövning av behoven borde ha gjorts. Det enda omedelbara frågetecknet är den rekommenderade kopplingen till NIB. Denna bank har idag ingen erfarenhet av den aktuella typen av riskkapitalfinansiering. Tvärtom kan bankens huvudsakliga finansierings-verksamhet placeras i andra ändan av ett spektrum för risktagande, d.v.s. traditionell utlåning med goda säkerheter av olika slag. Att banken i ett slag skulle röra sig till den andra extremen verkar i sig olämpligt. Dessutom förutsätter det en uppbyggnad av resurser och kompetens i NIB eftersom verksamheten i fråga, även som fond i fond, är relativt personalkrävande. NIB bör i stället gradvis bredda sin arsenal till att omfatta olika mellanformer av finansiering med relativt lägre risktagande, s.k. mezzaninfinansiering. En sådan utveckling är redan på gång.

Ett självklart alternativ till NIB vore att samarbeta med EIF, t.ex. i form av ett särskilt joint venture. EIFs primära verksamhet och kompetens är just stöd till mindre företag genom investeringar i riskkapitalfonder och garantier. Detta alternativ har övervägts i utredningen men tillbakavisas med hänvisning till argument som att den nordiska regionen inte skulle få tillräcklig uppmärksamhet i en sådan fond eller att Norge och Island inte är EU-medlemmar och därmed inte faller under EIFs investeringsaktiviteter. Inget av dessa argument är övertygande. Norge och Island kan redan utnyttja en del av de finansieringsordningar som EIF administrerar på uppdrag av EU-kommissionen. En samlad nordisk-baltisk fond 
torde inte heller "underkännas" av EIF för att två av totalt åtta länder inte är medlemmar i EU. Möjligheten att ge en EIF-anknuten fond en nordisk prägel bestäms primärt av dess utformning och uppläggningen av förvaltningen. I hög grad blir det frågor som får analyseras i samråd mellan de nordiska initiativtagarna och EIF. Kontakter med EIF tyder på att fonden är mycket flexibel vad gäller den närmare utformningen av en fond. En tänkbar förebild finns redan i form av ERP-EIF Dachfonds som EIF förvaltar på uppdrag av Tyskland. Totalt sett verkar det rimligt att först studera EIF-alternativet innan andra lösningar övervägs för en nordisk venture capital-fond.

NIF är tänkt att inrikta sin verksamhet på Norden och Baltikum med viss - relativt begränsad - möjlighet att engagera sig i projekt utanför dessa länder. Om de nordiska länderna vill stärka sin arsenal av internationella riskkapitalinstrument $\mathrm{i}$ andra länder i regionen kan ett utvidgat samarbete med övriga relevanta IFIs, som EBRD eller IFC, också övervägas. Närmast till hands förefaller ligga att samarbeta med EBRD som Norden tidigare gjort gemensamma eller individuella satsningar med, särskilt inom ramen för Baltiska investeringsprogrammet (BIP). I detta syfte kunde man skapa en fond i EBRD vars verksamhet överensstämmer med mottagarnas prioriteringar och som samtidigt möjliggör främjande av nordiska intressen.

En EBRD-anknuten fonds resurser skulle kunna användas såväl till tekniskt bistånd som till kompletterande finansiering av olika slag. Här finns också samarbetsmöjligheter med nationella riskkapitalorgan i Norden med mandat att verka i regionen (t.ex. IÖ-fonden, Finnfund och Swedfund) liksom med NEFCO, vilket kan ge ökad utväxling på fondens insatser. För att anpassa till de olikartade finansieringsbehoven i berörda transitionsländer kunde en sådan gemensam fond i EBRD bestå av två "fönster". Det första skulle avse investeringar i medelinkomstländer med relativt hög BNP per capita, främst Ryssland, där liknande samarbetsprojekt med EBRD prövats tidigare. Det andra fönstret skulle inriktas på investeringar i Ukraina, Vitryssland samt eventuellt andra OSS-länder. En sådan uppdelning är också rimlig med hänsyn till att de nationella bidragen skulle hämtas från olika delar av budgeten. För att ett samarbete mellan EBRD och nordiska riskkapitalorgan skall fungera tillfredställande krävs en effektiv projekthantering som gör att dubbelarbete undviks.

En annan variant av samverkan, som dock inte ger samma profilering, vore en nordisk insats via EBRDs speciella fondfacilitet (Private Equity Funds Co-Investment Facility), vilket skulle möjliggöra investeringar i ägarkapital parallellt med banken.

Avgörande fördelar med denna typ av lösning är att de nordiska länderna kan utnyttja respektive IFIs särskilda expertis på området liksom institutionernas tyngd i dialogen med företrädare för centrala eller lokala myndigheter. Samtidigt kan såväl privatsektorutveckling i samarbetsländerna som nordiska intressen främjas. Flexibiliteten hos IFIs att ut- 
forma arrangemang efter samarbetspartnernas önskemål är dessutom betydande. Det ställer i sin tur krav på de nordiska länderna att nå fram till en gemensam och en relativt tydlig uppfattning om hur ett samarbetsavtal bör se ut redan innan överläggningarna med IFIs inleds.

\subsubsection{Andra tänkbara insatser på innovationsområdet}

Inom ramen för Lissabon-strategins partnerskap för tillväxt och sysselsättning kommer EU under de närmaste åren att genomföra mycket betydande satsningar på forskning och utveckling. Tonvikten ligger på framtidsindustrier som informations/kommunikationssektorn och bioteknik. Det sjunde ramprogrammet för forskning och utveckling, som täcker perioden 2007-13, är avsett att stärka samarbetet med industrin och att främja småföretagens tillväxtmöjligheter. Vid sidan av forskningsprogrammet skall ett nytt program för konkurrenskraft och innovation (Competitiveness and Innovation Programme, CIP) som inleddes 2007 sammanföra en rad olika insatser för att stärka entreprenörskapet samt främja användning av IT och ny miljöteknik. En del av dessa satsningar kanaliseras via eller kombineras med medel från EUs finansieringsinstitutioner, d.v.s. EIB och EIF. Kommissionen och EIB har dessutom enats om en särskild riskdelningsfacilitet (på upp till $€ 2$ miljarder) som underlag för ökad EIB-finansiering inom forsknings- och innovationsområdet. Inriktningen är främst på forskningsintensiva medelstora företag.

Det målmedvetna arbete som nu pågår inom EU att diversifiera användningen av olika stödmedel såsom strukturfonderna samt att kombinera resurser från EU-budgeten med insatser från olika IFIs kommer att öppna nya möjligheter som länderna i regionen måste söka utnyttja. Särskilt intressant är den förnyade satsningen på att hjälpa SMEs att få tillgång till lämplig finansiering för tillväxt. Även om program som CIP är ett EU-program finns det möjligheter för länder som Norge och Island att delta.

De relativt ambitiösa innovationspolitiska program som genomförts eller pågår i Östersjöregionen på subregional eller lokal nivå, ofta med stöd av medel från EU, bör kunna utgöra underlag för projekt som får finansiering inte enbart via EU-budgeten utan också från finansieringsinstitutionerna. Den nordiska ambitionen att utveckla ett integrerat forsknings- och innovationsområde (NORIA) bör kunna leda till att gränsöverskridande satsningar underlättas. Nordiska institutioner som Nordisk InnovationsCenter och NordForsk, som gradvis breddar sin verksamhet till hela Östersjöregionen, har förutsättningar att medverka till konkreta samarbetsprojekt med IFIs. Andra exempel är förslag som kan framkomma ur breda regionala projekt på innovationsområdet som BSR INNOnet och BaltMet Inno eller ur ScanBalt som syftar till att skapa en kunskapsbaserad bioekonomi i regionen. Mera osäkert är om arbetet i de grupper för innovationspolitik i regionen som sponsras av NMR kan leda 
fram till egentliga projektförslag, även om ambitionen är att identifiera konkreta områden för transnationella eller regionala åtgärder.

En generell reflexion är att det - vid sidan av de initiativ som nu berörts - görs för få ansträngningar på nordiskt håll att knyta samman en aktiv dialog om innovationspolitik med de följande stegen för att medverka till olika projektförslag finansieras bl.a. av multilaterala finansorgan med särskilda konkurrensfördelar. Det myckna talet om Östersjöregionen som en världsledande region för innovationer och om det nära samarbetet mellan företag, universitet och regeringar följs inte upp av tillräckligt många konkreta projekt över gränserna. Ett huvudskäl till detta, vilket framhållits i tidigare utredningar ${ }^{6}$, är säkert svårigheten att överbrygga traditionella nationella perspektiv. Ett annat skäl är troligen brist på kunskap om vilka finansieringsmöjligheter som bör utnyttjas. Världsbanken har i en färsk studie granskat de olika stödmekanismer som finns i OECD-länder och försökt bedöma deras lämplighet för länder i Östeuropa och Centralasien. ${ }^{7}$ Studien förordar tre typer av instrument som det mest effektiva och samtidigt minst snedvridande: små gåvobidrag i initialfasen ("minigrants"), matchande bidrag och riskkapital. NIB kunde få i uppdrag att närmare granska om och hur innovativa finansieringsinstrument - vid sidan av rena venture capital-insatser - skulle kunna utnyttjas för att främja det regionala samarbetet på detta sakområde. En sådan utredning kunde delvis finansieras från den nordiska budgeten.

\subsection{Energi}

Inom energisektorn sker idag ett regionalt samarbete inom ramen för BASREC, Baltic Sea Region Energy Cooperation, som bildades 1999 baserat på ett tidigare initiativ av de nordiska statsministrarna. Deltagare är regionens 11 länder, EU-kommissionen samt generella regionala samarbetsorgan. Ett viktigt resultat är överenskommelsen om att göra Östersjöregionen till ett försöksområde för klimatinvesteringar (Testing Ground Agreement). I anknytning till detta avtal, som Ryssland dröjt med att underteckna, skapades den tidigare nämnda investeringsfonden för klimatprojekt, Testing Ground Facility, förvaltad av NEFCO. Förutom de nordiska länderna och Tyskland har deltagare från den privata sektorn investerat i denna fond. Faciliteten är alltså uppbyggd som offentligprivat samverkan, PPP, och har ett totalt kapital på € 35 miljoner. Det är av intresse att notera att TGF kommer att verka även i Ukraina.

Inom energisektorn pågår också ett omfattande samarbete mellan IFIs och biståndsmyndigheter i enskilda nordiska länder för stöd till projekt i transitionsländerna, kanske särskilt avseende effektivisering och näralig-

\footnotetext{
${ }^{6}$ I t.ex. IKEDs utredning Innovation in the Nordic-Baltic Sea Region - A Case for Regional Cooperation, 2004.

${ }^{7}$ Public Financial Support for Commercial Innovation, Europe and Central Asia Knowledge Economy Study, World Bank, 2006.
} 
gande miljösatsningar. Energisektorn är central för den regionala utvecklingen och för samarbetet mellan nordiska länder och IFIs. Den fråga som står i centrum i det här sammanhanget är dock en annan, nämligen om det skulle vara motiverat med additionella och gemensamma nordiska insatser, speciellt riktade mot IFIs, för att stärka ett regionalt samarbete inom energipolitiken. Av skäl som närmare utvecklas i det följande är den övergripande slutsatsen att sådana additionella insatser knappast hör till de prioriterade.

Ett första faktum som försvårar ett förstärkt regionalt samarbete avseende sektorn i dess helhet är att energifrågorna har fått en sådan politisk laddning att hanteringen alltmer centraliseras. På europeisk nivå betyder detta centralisering till Bryssel och Moskva med Norge som en tredje viktig aktör. I EUs särskilda energidialog med Ryssland, som är en del av det strategiska partnerskapet, har EU:s ambition angetts vara att "utvidga den inre marknaden" till länder utanför medlemskretsen. Redan i dag svarar Ryssland för ca $44 \%$ av EUs totala gasimport och runt $30 \%$ av unionens import av olja.

Enligt EU-kommissionen bör man på sikt röra sig i riktning mot en energigemenskap mellan Ryssland och EU. Europeiska Rådet antog i mars 2007 en omfattande handlingsplan på energiområdet för perioden 2007-09. Planen innehåller riktlinjer för en samordnad "internationell energipolitik" och betonar behovet av att EU talar med en röst. På global nivå har energifrågorna i växande utsträckning kommit att behandlas mellan de största industriländerna inom G8s ram. G8 har initierat en dialog om ren energi, klimatförändringar och hållbar utveckling i vilken enbart ett fåtal av Östersjöländerna deltar.

BASREC som regionalt organ kan, trots de långtgående ambitionerna på andra håll, ändå ha betydelse som ett forum för utbyte av information och erfarenheter, inte minst mellan företrädare för offentlig sektor och näringsliv. Vid det senaste ministermötet i BASREC under Islands CBSS-ordförandeskap konkluderades att det regionala samarbetet skulle visa stark komplementaritet med EU-Rysslandsdialogen. Dessutom beslöts att BASREC-samarbetet skulle förlängas till 2008. Samtidigt aviserades en översyn av dess struktur.

Det verkar dock uteslutet att BASREC under de kommande åren skulle kunna få en verklig roll som samordnande organ. Från rysk sida har tydligt markerats att man inte anser att detta samarbete är särskilt prioriterat och man deltar inte heller särskilt aktivt. Även andra länder i regionen verkar ha en relativt ljum inställning, vilket återspeglas i finansieringssvårigheter och i ett anmärkningsvärt dåligt högnivådel-tagande vid nyssnämnda ministermöte i BASREC. Det kan också noteras att de regionala organen inte spelar någon egentlig roll $\mathrm{i}$ beredningen av viktiga energiprojekt som har mycket stora konsekvenser för regionens länder. Ett slående exempel är den planerade gasledningen i Östersjön. 
Av energipolitikens särskilda status följer för det andra att IFIs roll på området tydligare än annars blir den kompletterande finansiärens. Övergripande politiska hänsyn bestämmer identifieringen av projekt. IFIs kommer möjligen in i ett senare skede när nationella instanser i huvudsak bestämt inte bara inriktningen i stort utan också vilka konkreta projekt som det skall satsas på. Det är med andra ord svårt att se att finansinstitutionerna här kan användas som en form av "hävstång” i prioriteringsprocessen, vilket inte alls är uteslutet inom andra sektorer.

Det sagda innebär inte att Norden inte bör eller inte kan agera proaktivt för att påverka en gemensam europeisk energistrategi eller för att fördjupa energidialogen med Ryssland på olika sätt, t.ex. inom ramen för Nordliga dimensionen, där även Norge och Island är fullvärdiga deltagare. Det innebär endast att en satsning på ett särskilt energipartnerskap eller andra former för liknande regionala särarrangemang verkar orealistisk.

Finland har föreslagit att partnerskapskonceptet skall omfatta samarbete också vad gäller energieffektivisering och förnybar energi, i första hand i anknytning till NDEP. Europeiska Ekonomiska och Sociala kommittén har förordat ett särskilt partnerskap för energi med liknande inriktning. I den politiska deklarationen från ND-ministermötet i november 2006 hänvisas till att möjligheterna till förstärkt samarbete på nämnda två områden skall granskas, dock utan tydlig koppling till ett visst partnerskap. Eftersom energieffektivisering redan ingår i NDEP är området i sig inte nytt. Det finländska initiativet syftar, såvitt kunnat utrönas, i första hand att bereda utrymme för vissa småskaliga projekt som hittills inte inkluderats och som kan finansieras av t.ex. NEFCO. Avsikten med att föra in projekten under NDEP skulle vara att underlätta upprioritering i Ryssland snarare än att möjliggöra tillgång till partnerskapets gåvomedel. Frågan är dock om NDEP-modellen skulle vara en effektiv samarbetsstruktur för småprojekt med tanke på flertalet IFIs arbetssätt och den omfattande administrativa apparat som modellen är förenad med. Det torde förutsätta en "pooling” av ett antal mindre projekt, vilket i sig också är en komplicerad procedur. Om och hur mindre effektiviseringsprojekt skall kopplas till NDEP bör därför utredas ytterligare.

IFIs pågående aktiviteter på energiområdet bör också beaktas när behovet av additionella insatser bedöms. Av särskilt intresse är att EBRD, som ett svar på slutsatserna från G8:s toppmöte 2005, lanserat en omfattande satsning på hållbar energi (Sustainable Energy Initiative). Initiativet innebär att banken skall öka sina insatser avseende energieffektivitet och rena energikällor samtidigt som samarbetet med andra internationella organisationer skall fördjupas och ett partnerskap med tänkbara givarländer upprättas. Siktet är inställt på att fördubbla investeringarna i energieffektivisering och ren energi under perioden 2006-08. Ett tiotal länder, däribland Sverige, har gjort utfästelser om bidrag till initiativet. EBRD avser dessutom att i ökad omfattning samarbeta med internationella aktörer som IEA, Världsbanken, EU och EIB på energiområdet. I detta ingår 
medverkan i arbetet på att utveckla innovativa finansieringsinstrument speciellt för klimatprojekt. Slutligen avser EBRD söka få gåvostöd från ägarna - i första hand för tekniskt bistånd inom energiområdet - om totalt $€ 100$ milj för den aktuella treårsperioden.

Utöver dessa specifika satsningar sker en kontinuerlig samordning mellan olika finansiärer - inklusive de multilaterala - i anknytning till genomförandet av transeuropeiska nätverk inom energisektorn (TEN-Es). Den mångfald av energiinitiativ som redan realiseras eller är under beredning i olika IFIs kan ses ytterligare ett skäl för återhållsamhet vad gäller försök att lansera nya program specifikt avsedda för Östersjöregionen och dess närområde. Marknaden är helt enkelt mättad.

\subsection{Finansiell sektor}

Den fortgående finansiella integrationen i Östersjöregionen har under senare år varit ett viktigt tema i diskussionen mellan representanter för regeringarna i området. Vid de regelbundna konferenserna mellan finansministrarna från de 11 länderna har frågan om förstärkt samarbete inom den finansiella sektorn behandlats vid ett flertal tillfällen. Vid mötena 2005 och 2006 grundades debatten på en omfattande utredning om hur regionen påverkades av pågående förändringar i världsekonomin, inklusive utvidgningen av $\mathrm{EU}^{8}$.

Utredningen utmynnar i ett förordande av att det regionala samarbetet ägnas åt tre strategiska prioriteringar för att främja utveckling och tillväxt: marknadsintegration, fortsatta reformer inom den finansiella sektorn och ökade insatser för utveckling av humankapitalet.

När det gäller den finansiella integrationen framhålls angelägenheten av att reducera antalet tillsyns- eller regleringsförfaranden och att undvika divergerande tolkningar av EU-regler. Utredningen diskuterar möjligheterna för ett gemensamt tillsynsorgan eller ett begränsat antal "lead regulators” på specifika områden. Konsekvent tillämpning av en "hemlandsprincip" skulle kunna utgöra ett viktigt steg mot ett förenhetligande. Harmonisering av andra regelverk skulle också kunna underlätta den finansiella integrationen. Sammantaget skulle sådana åtgärder kunna påskynda regionens genomförande av åtgärderna i EUs handlingsplan för finansiella tjänster.

Diskussionerna i finansministerkretsen visade att det inte förelåg enighet om att accelerera samarbetet på det finansiella området i enlighet med utredningens förslag. Särskilt påpekades risken för dubbelarbete om regionens länder skulle ha ambitionen att "gå före" den process som följde av EUs handlingsplan. Ministrarna kunde endast enas om att överlåta

\footnotetext{
${ }^{8}$ EU Enlargement, its Economic Opportunities and Challenges in the Nordic and Baltic Sea Region and Their Implications for Government Policy. Utredningsarbetet leddes av Erik Berglöf, f.n. chefekonom i EBRD.
} 
åt Norge, som svarar för ordförandeskapet 2006/07, att bestämma om och hur den aktuella utredningsrapporten skulle följas upp. Det förefaller inte sannolikt att initiativet förs vidare.

CBSS's näringslivsråd har samtidigt tagit ett initiativ för att identifiera de olika hinder för finansiell verksamhet i regionen som uppkommer genom skillnader i lagstiftning eller praxis. Syftet är att presentera konkreta exempel på sådana hinder och ange förslag till harmoniserade eller likartade lösningar. I ett första skede gäller kartläggningsarbetet bankverksamhet. Tanken är att i nästa steg föra diskussioner med tillsynsmyndigheterna i varje land för att om möjligt åstadkomma att krav, definitioner och rutiner strömlinjeformas. Det finns också planer på att senare identifiera och söka avveckla hinder inom andra delar av den finansiella sektorn såsom aktiemarknaden och försäkringsverksamhet. De förslag om förenklingar som inte fick allmänt stöd vid Östersjöfinansministrarnas möten kan alltså till viss del komma att övervägas genom ett initiativ från näringslivet.

I det senaste decenniets uppbyggnad av den finansiella sektorn i Baltikum, Polen och Ryssland har IFIs spelat en mycket viktig roll. EBRD, NIB och Världsbanken har alla varit aktivt involverade i omfattande insatser. De nordiska länderna har också medverkat, såväl gemensamt genom Baltiska investeringsprogrammet som individuellt genom nationella riskkapitalorgan som Swedfund i Sverige. Dessa insatser har säkerligen underlättat dagens långtgående finansiella integration, framför allt mellan Norden och Baltikum.

IFIs har fortsatt en roll att spela inom den finansiella sektorn i länderna i fråga, både såsom leverantör av tekniskt stöd, t.ex. för institutionella reformer, och som samfinansiär till utländska investerare. Det kan gälla att anpassa befintliga banker till internationella standarder eller att använda dem för kanalisering av lån till SMEs. För utländska investerare är önskan om IFI-medverkan - främst kanske från EBRD och IFC - ofta kopplad till behov av riskdelning eller riskbegränsning. Det kan finnas anledning för de nordiska länderna att på vissa punkter överväga additionella insatser i samarbete med IFIs. Ett exempel är Ukraina där ett betydande utvecklingsarbete i den fragmenterade finanssektorn återstår att utföra, även om den utländska ägarandelen i banksektorn redan vuxit till ca 25 procent enligt EBRDs Transition Report för 2006. Behovet av kompletterande finansieringsinstrument är särskilt uttalat i småföretagssektorn. Som en första åtgärd kunde mera ingående diskussioner föras med olika IFIs, kanske i första hand EBRD. När tiden anses mogen, kan liknande sonderingar göras vad gäller Vitryssland. 


\subsection{Hälsa och välfärd}

Kampen mot smittsamma sjukdomar och åtgärder för att förbättra folkhälsan i regionen är centrala politiska prioriteringar för de nordiska länderna. Som ett instrument för att stärka det regionala samarbetet skapades 2003 ett särskilt partnerskap inom Nordliga dimensionens ram (Northern Dimension Partnership on Public Health and Social Well-being, NDPHS), baserat på verksamheten i en tidigare temporär arbetsgrupp. Trots betydande ansträngningar från olika håll har partnerskapet haft svårt att etablera sig som ett dynamiskt samarbetsforum.

En förklaring är att Ryssland, som samarbetet till betydande del har varit inriktat på, inte visat det engagemang och intresse som man kunde ha förväntat sig. Tidvis har det till och med varit svårt att etablera en fungerande kontakt med de ansvariga på federal nivå i landet. EUkommissionens något oförutsägbara beteende har också utgjort en komplikation och har bidragit till osäkerhet kring finansieringen av angelägna initiala satsningar. Även i övrigt har finansieringsfrågorna avancerat mycket långsamt. Andra svagheter är att beslutsförfarandet är omständligt och att orimligt mycket tid lagts ned på vissa institutionella frågor, t.ex. status för partnerskapets sekretariat inom CBSS ram. Vid de intervjuer som gjorts för utredningen framkom i vissa länder missnöje med hur ordförandeskapet för NDPHS har skötts. I ett par fall har deltagare lämnat partnerskapet, medan ett viktigt land som Tyskland inte är fullvärdig deltagare utan "associerad partner". Totalt omfattar NDPHS för närvarande 13 länder.

Ett sammanfattande omdöme måste bli att det starka intresset av framsteg på detta viktiga område inte alls kunnat översättas i snabba och konkreta insatser inom NDPHS' ram. Det vore en överdrift att beteckna partnerskapet som ett misslyckande, men den långsamma framstegstakten och organisatoriska senfärdigheten har onekligen haft negativa effekter på själva konceptet partnerskap i ND. Utvecklingen är därmed ett memento för planerna på nya partnerskap innebärande att beslut om upprättande bör föregås av en noggrann beredning i vilken bindande åtaganden görs av deltagarna oavsett om det gäller länder eller internationella organ. De krav på eventuella nya partnerskap som fastställdes vid NDministermötet i november 2006 kan sägas gå i en liknande riktning.

Med utgångspunkt i denna utrednings fokus är det dessutom förvånande att företrädare för NDPHS, i första hand ordförandeskapen, inte lyckats etablera en ordentlig dialog med de IFIs som har aktiviteter inom hälsoområdet. Den viktigaste institutionen i detta sammanhang är Världsbanken, som har omfattande utlåning och tekniskt samarbete med bl.a. Ryssland vad gäller kampen mot HIV/Aids och tuberkulos. En sonderande förfrågan gjordes under 2004, men bankens prioritering av projekt som avsåg hela federationen medverkade till att den inte följdes upp. Ett ytterligare skäl till försiktigheten i kontakterna med IFIs har angetts vara att 
det inte funnits tillräckligt stora projekt att diskutera. Avsaknaden av "färdiga” projekt bör givetvis inte avhålla ett partnerskap som inriktar sig på framtida IFI-finansiering från att initiera en aktiv dialog. En sådan dialog med Världsbanken skulle ha kunnat ge NDPHS värdefull hjälp och kunskap i flera olika avseenden, t.ex. genom att underlätta myndighetskontakter i Ryssland och ge bättre underlag för att säkra att NDPHS insatser blir additionella.

Passiviteten på denna punkt är särskilt märklig eftersom gemensamma uttalanden gjorts om att försöka mobilisera medel från bl.a. IFIs alltsedan starten 2003. Världsbankens regionansvariga har därtill - i samband med diskussioner för denna utredning - å sin sida klargjort att man skulle välkomna en dialog. Dessutom finns det numera ökade möjligheter för subregionala projekt i banken på grundval av erfarenheterna av federala hälsovårdssatsningar. Återigen kan en förklaring till den överdrivet passiva inställningen till IFIs vara att man på vissa håll önskar att regionala organisationer som CBSS skall stå i centrum för samarbetet.

Den utveckling av NDPHS som framhålls i den politiska deklarationen om ND från november 2006 bör alltså innefatta aktivering av kontakterna med IFIs. Att NDEP har angetts som förebild för andra partnerskap bör dessutom tolkas som att NDPHS bör lägga ner betydligt mera arbete på sådana kontakter. Det relativt kraftlösa uttalande om insatser på hälsoområdet som görs i kommunikén från CBSS' utrikesministermöte i juni 2007 ger dock inte mycket politiskt stöd för en revitalisering av partnerskapet.

\section{7 Övriga sektorer och konklusioner}

IFIs är verksamma i ett antal sektorer i Östersjöregionen utöver de ovan angivna. Det kan gälla olika former av institutionella reformer inom det bredare begreppet "governance", regionala nätverk, byggnadsverksamhet och förnyelse av stadsmiljöer, tjänstesektorn, turism, underlättande av handel m.m. I många projekt sker samarbete/samfinansiering med nordiska aktörer antingen det är fråga om nationella biståndsorgan eller privata företag eller finansiärer. De nordiska länderna har anledning att verka för att sådana gemensamma insatser kommer till stånd, men det är knappast regeringarnas uppgift att initiera nordiska program för att stödja verksamheten. Till det kommer ännu en gång att en stor del av de regionala - och ofta gränsöverskridande - projekt som genomförs får bidrag till finansieringen från EU-budgeten. Ett angeläget projekt, som huvudsakligen finansierats med EU-medel, är det gränsregionala samarbetet i Baltic Euroregional Network, BEN. Projektet berör de nordiska och baltiska länderna, Polen, Ryssland och Vitryssland. Riktlinjerna för EUs nya grannskapspolitik gör att projekt som berör icke-medlemsländer kommer att erhålla utökade bidrag. 
Den granskning som gjorts inom utredningens ram leder också till slutsatsen att det knappast finns någon ytterligare sektor som förtjänar prövning av en additionell nordisk insats i samarbete med IFIs. Behovet av koncentration talar dessutom för att diskussionen inriktas på ett hanterligt antal områden. De tre sektorer som här har prioriterats är miljö, transporter samt innovation och forskning. Därtill finns det anledning att från politisk nivå i Norden mera kraftfullt stödja NDPHS såväl direkt som via bearbetning av EU-kommissionen och att verka för att ett kontinuerligt samråd med andra aktörer med finansiella muskler, särskilt Världsbanken, kommer till stånd. 



\section{Olika IFIs roller i regionen}

\subsection{EBRD}

EBRD är verksam i alla transitionsländer i regionen, d.v.s. Estland, Lettland, Litauen, Polen, Ryssland och Ukraina samt - i starkt begränsad omfattning - i Vitryssland. Ett huvudvillkor för bankens medverkan i ett projekt är att det har en transition impact, d.v.s. medverkar till övergången till marknadsekonomi. Bankens privatsektororientering och kompetens vad gäller andra generationens reformer gör att den fortfarande har en uppgift i de nya EU-medlemsländerna. Samtidigt står det klart att en fortsatt snabb omvandling gör att dess roll gradvis avtar, vilket kan avläsas i den obetydliga nyutlåningen under senare tid till vissa samarbetsländer. Bankens senaste strategi innebär dessutom att fokus läggs på Ryssland, Sydösteuropa, Kaukasus och Centralasien. De många attraktiva finansieringsalternativen i marknaden för länderna i det nordiska närområdet medverkar till att efterfrågan på nya EBRD-lån avtar. Samtidigt har en diskussion förts, med anglosachsiska länder som pådrivande, om att de mest framgångsrika transitionsländerna bör "graduera”, d.v.s. inte längre ta upp ny finansiering från banken. Resultatet av denna diskussion är en överenskommelse om att de nya EU-medlemsländerna, exkl. Bulgarien och Rumänien, bör ha nått fram till denna punkt vid utgången av 2010.

Förändringarna i portföljen innebär att några av de stora samarbetsländerna svarar för en allt större del av EBRDs finansiering. Rysslands andel av bankens årliga affärsvolym (lån och aktieinvesteringar) beräknas uppgå till över $40 \%$ år 2010. Ukrainas motsvarande andel kan beräknas bli åtminstone runt 10 \% samma år. Inom några år kommer alltså mer än hälften av bankens affärsvolym att avse två länder. I dessa båda länder agerar banken över ett brett spektrum och dess insatser har varit strategiskt viktiga på flera punkter.

I linje med mandatet har EBRD varit särskilt aktiv när det gäller att utveckla små och medelstora företag. Det största enskilda programmet är Russian Small Business Fund, men liknande arrangemang finns för bankens övriga verksamhetsländer. Bankens finansiering kombineras ofta med givarstöd för att möjliggöra experthjälp eller annat tekniskt bistånd. Långivningen slussas vanligen via lokala banker eller specialiserade mikrofinansorgan som lånar vidare till företagen. Det har förekommit kritik mot bankens SME-program i Ryssland av innebörd att alltför stor del av resurserna lagts på redan etablerade entreprenörer eller de medelstora företagen. Efter hand har dock en avsevärd breddning av stödet till företagsutveckling skett. Ett annat profilområde för EBRD är miljöprojekt. 
Banken har gjort omfattande insatser, inte minst när det gäller kärnsäkerhet och klimatprojekt.

Det gradvisa bortfallet av ett antal låntagare i Europa kan till en del kompenseras genom ökade insatser i de regioner som banken nu fokuserar på. Möjligheterna att expandera affärsvolymen är dock begränsade i ett antal länder i Centralasien och i Kaukasus-området. De asiatiska länderna kan dessutom täckas av Asiatiska utvecklingsbanken, ADB. På längre sikt blir därför den oundvikliga frågan om det kan anses motiverat att ha en regional europeisk utvecklingsbank för ett relativt litet antal potentiella verksamhetsländer.

Situationen gör också att EBRDs ledning - kanske mera än systerinstitutionernas - är angelägen att behålla sin position som primär IFI i de länder där banken är verksam. Omvänt betyder detta att banken förefaller vara aktivt intresserad av samfinansiering eller andra former för samverkan. Banken har resurser för aktiv projektidentifiering och förenar dessutom kompetens i traditionell utlåning och i riskkapitalverksamhet. Det förtjänar nämnas att det var EBRD som skisserade det egentliga upplägget för NDEP, även om det var det svenska EU-ordförandeskapet 2001 som tog initiativet till samrådet mellan IFIs. Bankens svaghet å andra sidan, som dock synes ha reducerats med åren, är att den med sitt något aktivistiska agerande ibland har haft svårt att samarbeta med andra aktörer, inte minst med andra IFIs.

EBRDs komparativa fördelar gör att de nordiska länderna i överväganden om nya insatser tidigt bör ta upp en diskussion med banken om formerna för tänkbart samarbete. En samnordisk satsning på riskkapitalområdet tillsammans med EBRD förefaller särskilt intressant. Ett förstahandsalternativ vore att de nationella nordiska riskkapital-bolagen samverkade inom ramen för ett "joint venture” med EBRD. De nordiska representanterna i bankens styrelse bör kunna medverka till att effektivt bereda sådana diskussioner.

\subsection{EIB/EIF}

EIB-gruppen är EUs finansieringsinstrument och en allt viktigare aktör i unionens samlade politik på de ekonomiska och finansiella områdena. Banken, vars huvuduppdrag är att stärka ekonomisk och social sammanhållning inom unionen, har solid erfarenhet av finansiering av stora infrastrukturprojekt samt av finansiering av SMEs via olika mellanhänder i medlemsländerna. EIB är, räknat efter utlåningsvolym, världens största IFI. Bankens samlade utlåning uppgick 2006 till cirka $€ 46$ miljarder.

Bankens styrka i detta sammanhang är att den kan vara verksam inte enbart i EUs medlemsländer utan även i övriga länder i regionen. Utlåning kan ske till Norge och Island enligt ett särskilt EFTA-mandat som efter senaste förlängning gäller till utgången av 2009. För verksamheten i 
tillväxtekonomier och u-länder har nyligen externa lånemandat med åtföljande gemenskapsgaranti fastställts. För perioden 2007-13 anges ett tak för utlåningen till Östeuropa, Ryssland och Södra Kaukasus på € 3,7 miljarder. EIBs finansiering i dessa länder skall i första hand avse sektorerna transport, energi, telekommunikationer och miljö. Dessutom understryks att EIBs utlåning skall ske i nära samarbete med EBRD enligt den överenskommelse som behandlas nedan.

EIB har karaktär av en "grosshandelsbank" som traditionellt tagit mycket begränsade risker. Under senare år har EIB utvidgat sin uppsättning av instrument, ofta i nära samarbete med EU-kommissionen, för att kunna finansiera mera riskfyllda projekt inom exempelvis infrastruktur samt forskning och utveckling. Syftet är samtidigt att mobilisera additionellt privat kapital. Verksamheten har dessutom tydligare inriktats på insatser där EIB kan skapa ett verkligt mervärde. Banken har också sökt avhjälpa bristen på personella resurser för att identifiera och bereda projekt. För att förstärka kapaciteten på denna punkt och för att nå allmänna synergieffekter har EIB, EBRD och EU-kommissionen nyligen träffat överenskommelser som innebär fördjupat samarbete mellan de tre parterna såväl i unionen som i grannländerna.

För medlems- och kandidatländer skapades häromåret en ny projektberedningsfacilitet JASPERS, Joint Assistance to Support Projects in European Regions. Syftet med faciliteten är att ge tekniskt stöd i projektutformningen alltifrån identifikationsfasen till tidpunkten för begäran om stöd från EU-budgeten. Detta skall möjliggöra högkvalitativa ansökningar som snabbt kan godkännas av kommissionen. I rådgivningen ingår också hjälp till att strukturera finansieringen av projekten. Det finns inget krav på att ett medlemsland skall låna från EIB eller EBRD till projekten ifråga, lika litet som bankerna med automatik lånar ut till varje projekt som beretts under JASPERS. Den nya faciliteten väntas få särskild betydelse för större infrastrukturella investeringar. Ett JASPERS-kontor som täcker Polen och de baltiska länderna har nyligen upprättats i Warszawa.

För grannländer som Ryssland och Ukraina har EIB, EBRD och kommissionen 2006 ingått en överenskommelse om samfinansiering som delvis bygger på det framgångsrika samarbetet inom NDEPs ram. Överenskommelsen, som även berör länder i Kaukasus och Centralasien, är inriktad på större infrastrukturprojekt (energi, transport, telekom, miljö) av betydande intresse för EU. Samarbetet bygger på ett omfattande informationsutbyte som täcker hela projektcykeln och på att institutionerna skall kunna utnyttja allt analysunderlag. EIB kan alltså luta sig mot EBRDs särskilda landkompetens. I princip skall alla projekt som EIB satsar på i de aktuella länderna samfinansieras av EBRD. De båda bankerna skall också lägga fram gemensamma anbud (joint offers) till låntagarna. Liksom med JASPERS är förväntningarna att samordningen skall leda till att beredning och finansieringsbeslut skall påskyndas så att angelägna projekt kan genomföras snabbare. 
För EIBs del kan det förstärkta samarbetet med EBRD ha positiva effekter på verksamheten i Ryssland som ännu så länge varit relativt blygsam. Under en inledningsfas avsåg utlåningen till Ryssland uteslutande projekt inom NDEPs ram. EIBs huvudsakliga inriktning mot infrastrukturprojekt, vilka ofta genomförs i statlig regi, och den ryska statens ovilja att låna utomlands förklarar de låga lånevolymerna. Det begränsade intresset sammanhänger givetvis med att den offentliga sektorns lånebehov minskat drastiskt. Allmänt sett förefaller Ryssland dessutom vara mera intresserat av "signaleffekten" av tillgång till EIBs resurser än av att faktiskt utnyttja dessa. På senare tid har man dock från rysk sida visat ökat intresse för att pröva PPP-lösningar vid olika vägprojekt och man kan då behöva extern expertis från t.ex. EIB och EBRD.

EIB har under senare tid särskilt profilerat sig på energi- och miljöområdet, bl.a. genom att uppställa mål för finansieringen av satsningar på förnybar energi. EIBs aktiviteter på klimatområdet har berörts ovan vad gäller den med EBRD gemensamma multilaterala "kolkreditfonden". Liknande fonder har inrättats i samarbete med Världsbanken och tyska Kreditanstalt für Wiederaufbau. Dessutom planerar EIB, i samarbete med andra finansiärer, att skapa en "post-2012 fond" som kan fungera under perioden efter det att Kyoto-protokollet upphört att gälla. EBRD och NIB har inviterats till överläggningar kring en sådan fond. Denna diskussion förutsätter sannolikt överenskommelser om bättre fungerande system för handel med utsläppsrätter än de hittills tillämpade.

EIB-gruppens andra del, EIF, ägs gemensamt av EIB, kommissionen och europeiska finansinstitutioner. Fonden fokuserar på stöd till små och medelstora företag i form av riskkapitalinsatser och garantier. EIF gör inte några direkta investeringar i företag utan arbetar enligt fond $\mathrm{i}$ fondmodellen. EIF förvaltar även betydande medel som EU-kommissionen valt att kanalisera via fonden. Ambitionen är att särskilt stödja innovativa eller teknologiorienterade företag i tidiga skeden. I detta syfte söker EIF utveckla nya riskkapitalinstrument som kan underlätta lansering och marknadsföring av innovationer.

EIF och EU-kommissionen enades 2005 om ett nytt samarbete som avser att förbättra möjligheterna att utveckla småföretag i medlemsländerna. Som redan nämnts är bristen på lämplig finansiering ett väsentligt hinder för de mindre företagen, speciellt i flertalet transitionsländer. Genom samarbetet, som getts akronymen JEREMIE (Joint European Resources for Micro to Medium Enterprises Initiative), kan ett medlemsland lägga ut förvaltningen av en del av allokerade strukturfondsmedel till EIF. I nästa steg omvandlas medlen till finansiella produkter som stödjer utveckling av småföretag. Efter återbetalning kan medlen reinvesteras. Syftet är därutöver att få bättre utväxling genom att JEREMIE kombineras med finansiering från EIB och andra internationella eller nationella aktörer. Komplikationen med JEREMIE förefaller vara att man på regional/lokal nivå måste godta att redan allokerade medel används för andra 
syften. Den tydliga småföretags-inriktningen och breda kompetensen gör dock EIF allmänt sett till en intressant samarbetspartner, exempelvis för en nordisk investeringsfond enligt det förslag som berörts ovan.

\subsection{Världsbanksgruppen (IBRD, IFC, MIGA)}

De delar av Världsbanksgruppen som är intressanta i detta sammanhang är IBRD, som sysslar med traditionell utlåning till medlemsländerna, IFC, som ägnar sig åt privatsektorutveckling och MIGA, vars huvudsakliga aktivitet är garantigivning. Gruppen har under en lång tid varit en viktig finansiär för länderna i Östeuropa. IBRDs utlåning har dock gradvis minskat parallellt med att stora framsteg gjorts i den ekonomiska omvandlingen. Estland och Litauen "graduerade" från banken 2006, medan Lettland fullföljde samma procedur i april 2007. Detta betyder att de tre länderna inte avser att låna upp mera från institutionen.

För Rysslands del har IFC och MIGA med deras privatsektorbetoning blivit viktigare än IBRD. Den traditionella bankutlåningen avser i växande grad utlåning till enskilda regioner, varvid finansieringsinstrument som inte kräver statlig garanti kommer till växande användning. I Ukraina är Världsbanken alltfort en väsentlig samarbetspartner som medverkar till att ekonomiskt reformarbete och nödvändigt institutionsbyggande drivs vidare.

Världsbanken som institution anpassar sig löpande till pågående - i och för sig naturliga och välkomna - förändringar genom att avsätta mindre resurser för arbetet i regionen. Det bör dock framhållas att banken fortsatt har en viktig funktion att fylla när det gäller tekniskt stöd av olika slag, vilket styrks av att samarbetsländerna på vissa områden är beredda att själva finansiera sådant stöd. Det är oomtvistligt att banken har en utomordentligt stor kompetens på ett stort antal sakområden alltifrån klassisk projektfinansiering till verksamhet inom sektorer som hälsovård, utbildning, energieffektivisering och samhällsstyrning. Det är angeläget att denna kompetens tas till vara också i Östersjöregionen och dess närområde. När det gäller Ryssland överlägger banken med de federala myndigheterna om att identifiera 6-10 regioner som kan bli föremål för koncentrerade samarbetsprogram. Andra tydliga exempel på behov av medverkan från Världsbanken är ovan redovisade partnerskap på hälsoområdet och det planerade partnerskapet för transport och logistik. På klimatområdet har banken varit banbrytande genom att inrätta olika mekanismer för att minska utsläppen av växthusgaser.

Behovet av att lyfta fram Världsbankens kompetens sammanhänger också med de tendenser till onödig konkurrens mellan IFIs som närmare kommenteras nedan. Det måste anses ligga i de nordiska ländernas och hela regionens intresse att samtliga internationella finansinstitutioner ges möjlighet att delta fullt ut i det uppbyggnadsarbete som alltjämt pågår. 
Trots existerande samarbetsavtal är detta inte alltid fallet. Det finns oroväckande tecken på att gemensamma europeiska aktörer - i ivern att ge nya initiativ en tydlig EU-prägel - avsiktligt eller oavsiktligt förbiser att andra institutioner eller finansiärer har värdefulla bidrag att ge.

IFCs aktiviteter i de aktuella länderna har koncentrerats till utveckling av den finansiella sektorn och av infrastrukturen samt investeringar i småföretagsfonder. Även riktade insatser för att främja entreprenörskap har gjorts via Russian Women's Microfinance Network. IFC är också engagerat i flera andra områden som exempelvis reformer av bostadsfinansieringen. De dominerande investeringsländerna i Central- och Östeuropa är Ryssland och Ukraina. Ryssland är också garantiorganet MIGAs största kund.

Banken och IFC svar dessutom för flera olika initiativ som syftar till att bereda väg för bättre affärs- och investeringsmiljöer i medlemsländerna. Av särskild betydelse är den årliga rapporten Doing Business som i detalj redovisar regleringar eller bestämmelser som försvårar - eller underlättar - affärsverksamhet. Även om av dessa uppgifter kan sägas ge en något förenklad bild av förutsättningarna i respektive land, medverkar publiceringen till väsentligt ökad kunskap och därmed till mera välunderbyggda krav på förändringar. Liknande sammanställningar görs för uppgifter om styrning (WBI Governance Indicators) och för administrativa hinder (Administrative Barrier Assessments).

\subsection{NIB, NEFCO och Nopef}

NIB med åtta ägarländer är i jämförelse med ovan behandlade IFIs en liten institution såväl vad gäller årlig lånevolym som personella resurser. Trots detta har banken genom sin flexibilitet och kompetens lyckats hävda sig väl i det regionala samarbetet. I likhet med andra IFIs står NIB inför strategiska avgöranden som sammanhänger med de fortgående förändringarna i bankens omgivning. Verksamheten i ägarländerna, särskilt de nordiska, tenderar att stagnera och denna utveckling kan väntas fortsätta under överskådlig tid. Marknaden erbjuder numera även potentiella låntagare i Estland, Lettland och Litauen synnerligen konkurrenskraftiga finansieringsalternativ. Aktiviteterna utanför Norden och Baltikum rymmer å andra sidan större expansionsmöjligheter men här sätter hänsyn till portföljsammansättning och risktagande gränser för nya åtaganden.

Banken har nyligen - efter ett omfattande beredningsarbete - fastställt en reviderad strategi som utmynnar i fokusering på finansiering som stärker konkurrenskraften och förbättrar miljön. Strategin prioriterar utlåning till projekt inom fyra områden: infrastruktur, miljö, stora investeringar i företagssektorn samt små och medelstora företag i samarbete med finansiella mellanhänder. Inom banken pågår dessutom överväganden om att 
bredda instrumentarsenalen och i kontrollerade former öka risktagandet för att kunna finansiera innovativ verksamhet.

Den nya strategin ger egentligen inte särskilt mycket vägledning om vad banken skall satsa på utöver vad som hittills utgjort tyngdpunkter i verksamheten. En positiv tolkning av detta är att fortsatt flexibilitet framstår som nödvändig för att banken skall kunna anpassa sig till snabbt ändrade förutsättningar. De samtal som förts inom utredningens ram ger samtidigt intryck av en viss rådvillhet och brist på tydliga idéer, i så gott som samtliga ägarländer, om bankens framtida kurs. Ägarna i en institution som är exklusivt nordisk-baltisk kan emellertid, till skillnad från vad som gäller för de stora IFIs, inte komma ifrån ansvaret att gemensamt staka ut hur de vill att banken skall positionera sig. För det fortsatta tänkandet skisseras i det följande ett par utvecklingslinjer när det gäller NIBs verksamhet i Östersjöregionen och dess närområde. Förslagen går i allmänhet i riktning mot ökad specialisering. Det kan noteras att NIBs guvernörsråd vid sitt möte i maj 2007 enades om liknande slutsatser avseende bankens framtida inriktning.

Det bör dessutom än en gång understrykas att den nordisk/baltiska dimensionen är av särskild vikt när det gäller NIB eftersom Estland, Lettland och Litauen numera ingår bland bankens medlemmar. Förslag om preciseringar i bankens strategiska upplägg måste beredas i hela ägarkretsen, vilket enklast kan ske i bankens egna organ.

För en institution av NIBs karaktär gäller i särskilt hög grad att man måste anpassa sig till det existerande institutionella landskapet. Ett av flera viktiga hänsynstaganden avser samarbetet - alternativt konkurrensen - med andra IFIs. Med pågående omgrupperingar, och särskilt det förstärkta trepartssamarbetet EBRD/EIB/Kommissionen, vore det naturligt om NIB tog initiativ till regelrätta diskussioner med dessa parter om någon form av arbetsdelning som också innefattade banken. Detta kan ske med utgångspunkt i en tydligt deklarerad uppfattning att NIB har något att tillföra en långtgående interinstitutionell samverkan. Sådana diskussioner måste initieras av bankens exekutiva ledning. I en andra fas kan ägarländerna aktiveras för att exempelvis vid behov söka påverka inställningen hos Kommissionen eller enskilda viktiga EU-länder.

En ambition kunde därvid vara att skapa större klarhet kring möjligheterna att ge NIB ett primärt ansvarsområde eller nisch, t.ex. en roll som Östersjöbank inom ramen för ett brett institutionellt samarbete. En annan metod vore att försöka tydliggöra arbetsdelningen mellan olika IFIs för verksamhet inom sektorer som t.ex. kommunal infrastruktur, där projekt som inte är av "betydande intresse för EU” ligger utanför 2006 års överenskommelse mellan EBRD, EIB och kommissionen. Liknande diskussioner kunde föras med främst EU-kommissionen och EIB/EIF när det gäller mera generella satsningar inom områdena innovationer samt forskning och utveckling, exempelvis gränsöverskridande projekt för att främja olika former av kluster. Det måste anses ligga i den mindre institutio- 
nens, d.v.s. NIBs, intresse att sådana överenskommelser preciseras och formaliseras utöver vad som skett i tidigare avtal eller Memoranda of Understanding. Risken är annars att NIBs eventuella medverkan i projekten blir en residual.

Under utredningsarbetet har från NIBs sida framförts att ett helt parallellt agerande med andra IFIs kan försvåras av bankens uppdrag att främja de egna medlemsländernas konkurrenskraft. Det är möjligt att det går att peka på enstaka låneärenden där det finns en sådan komplikation eller motsättning. Att den närmast jämförbara IFIn, d.v.s. EIB, generellt skulle se mindre till de egna medlemmarnas intressen än vad NIB förutsätts göra är dock svårt att hävda. Centrala mål för den ekonomiska politiken i EU, och därmed även för EIB, är att öka tillväxtpotentialen och stärka innovationsförmågan inom unionen. Däremot är det självklart att EBRD och Världsbanken har andra huvuduppdrag, men de är i sig knappast avgörande hinder för ett nära samarbete.

Den framtida inriktningen kan alternativt formas genom att ge banken nya konkreta uppdrag som ger möjlighet till specialisering. När företrädare för ägarna tidigare angivit eller bidragit till omfattande och tydliga uppgifter för banken, såsom t.ex. medverkan i Baltiska investeringsprogrammet eller i NDEP, har banken förtjänstfullt utfört sina insatser. I avsaknad av en preciserad långsiktig strategi bör de nordiska och baltiska länderna söka identifiera liknande större uppgifter för de närmaste åren. Ett nytt partnerskap för transport och logistik vore, om det kommer till stånd, ett exempel på uppgift i vilken NIB i nära samarbete med övriga IFIs skulle kunna fylla en väsentlig funktion. NIB har redan medverkat aktivt i pågående beredningsarbete om NDTLP. Om de nordiska länderna enades om en särskild gemensam satsning på Ukraina kunde också detta ge NIB en utvidgad uppgift. Diskussionen om en riskkapitalfond i NIB har redan berörts. Övervägande skäl talar för att banken inte engagerar sig på detta område. Däremot är det rimligt att fortsätta med pågående omläggning mot ett ökat risktagande i kontrollerade former. Dessutom skulle NIB kunna bygga vidare på tidigare specialsatsningar för att främja företagsamhet i regionen som t.ex. att medverka i långivning till mikrooch småföretagare som har svårt att ordna erforderlig finansiering.

För att underlätta en mera proaktiv roll för NIB i samarbetet inom regionen uppkommer ånyo frågan om banken bör utrustas med ytterligare resurser för tekniskt bistånd av olika slag, t.ex. för projektförberedelser. NIB spelar redan idag en viktig roll som partner för nordiska projektexportföretag i det tidskrävande arbetet att utforma "bankable projects” och att finna lämpliga finansieringslösningar. Inom området infrastrukturella projekt, kanske särskilt i den kommunala sektorn, är behovet av kompletterande medel stort. Hittills har sådana medel ofta ställts till bankens förfogande genom bilaterala överenskommelser med enskilda ägarländer. Alternativet är att skapa en gemensam och permanent TA-fond som får regelbundna påfyllnader, eventuellt genom bokslutsdispositioner i banken. 
NEFCO har en bred instrumentarsenal med riskkapital, lån och olika mellanformer av finansiering. Denna bredd och förmågan att utveckla nya lösningar har gjort att bolaget fått större betydelse som finansiär än vad som följer av dess storlek. Bolaget kan verka i Baltikum, Ryssland, Ukraina och Vitryssland men har i dag sin huvudsakliga verksamhet i nordvästra Ryssland. Vid sidan av den ordinarie investeringsfonden finns inom bolagets ram flera specialordningar såsom en nordisk miljöutvecklingsfond för mjuk finansiering och den regionala klimatfonden TGF. Bolaget har dessutom utvecklat ett välfungerande samarbete med BEAC och AC och förvaltar speciella projektberedningsfonder (Barents Hot Spot Facility och Arctic Council Project Support Instrument). NEFCO har också fått i uppdrag att bereda finansieringsfrågorna i HELCOMs nya handlingsplan för Östersjön, Baltic Sea Action Plan, BSAP.

Med tanke på den dynamiska utvecklingen när det gäller finansiering av olika former av miljörelaterade insatser bör, som redan antytts, möjligheterna att finna innovativa modeller för finansiell medverkan granskas. Även för NEFCO gäller det att bygga vidare på existerande internationella kontakter och att i samråd med andra tänkbara finansiärer identifiera nya lösningar, t.ex. nya former av handel med utsläppsrätter eller liknande arrangemang. Ett sådant arbete pågår redan inom ramen för beredningen av BSAP. Utvidgningen av bolagets verksamhet i Ukraina - eventuellt i direkt samarbete med andra aktörer - bör vara en annan prioritet.

Nordiska projektexportfondens (Nopef) syfte är att stärka små och medelstora nordiska företags internationella konkurrenskraft genom att erbjuda förmånliga lån till förstudier vid internationalisering och projektexport i närområdet och i andra östländer. Den dominerande delen av Nopefs stöd går till etableringar. Fondens geografiska fokus har under senare tid alltmer kommit att ligga på nordvästra Ryssland. Verksamheten inriktad på Estland, Lettland, Litauen och Polen upphör vid utgången av 2007.

Fondens verksamhet är i sann mening småskalig men för den skull inte marginell. Nopefs stöd kan också genom sammankoppling med andra satsningar - nationella via t.ex. exportfrämjande organ eller multilaterala via t.ex. EU-budgeten - få större effekt än vad de faktiska beloppen indikerar. Det verkar dessutom finnas utrymme för ökade insatser för att bättre integrera Nopefs aktiviteter i den nordiska finansgruppen. Det samarbete som nyligen initierats mellan Nopef och NEFCO avseende SME-projekt i Ryssland och Ukraina är ett utmärkt exempel. Samarbetet ger Nopef möjlighet att hänvisa företagen till en alternativ nordisk finansiär och inte enbart till rent kommersiell finansiering via affärsbanker. 


\subsection{CEB}

Europarådets utvecklingsbank (CEB) har som syfte att bidra till att förbättra levnadsförhållandena och den sociala sammanhållningen i Europa. Utlåningen, som avser sociala projekt, miljöprojekt eller stöd till katastrofdrabbade, går primärt till eftersatta regioner. Verksamheten äger rum i de 39 medlemsländerna, vilket för regionens del innebär Norden, Baltikum, Polen och Tyskland. Banken kan däremot inte låna ut till ickemedlemsländer som Ryssland, Ukraina eller Vitryssland.

Banken har genom åren utvecklat ett närmare samarbete med flertalet övriga IFIs. Detta samarbete har också befordrat en breddning av verksamheten till områden som hälsovård, utbildning och stöd till småföretag via mellanhänder. Av speciellt intresse är den överenskommelse som CEB ingick 2006 med EIB och EU-kommissionen om samarbete avseende projekt som syftar till att utveckla och förbättra stadsmiljöer. Tanken är att de som förvaltar strukturfondsmedel från EU i ökad utsträckning skall kunna utnyttja extern expertis och additionella källor i verksamheten. Kombinationen av olika typer av finansiering ( lån, garantier, riskkapital) förväntas kunna påskynda genomförandet av angelägna projekt samtidigt som medlen kan återanvändas. Initiativet, som kallas JESSICA (Joint European Support for Sustainable Investment in City Areas), är det tredje inslaget - vid sidan av JASPERS och JEREMIE - i kommissionens samarbetsoffensiv gentemot IFIs för att främja tillväxt och sysselsättning i unionen.

CEB har på grund av en låg profil blivit något av den "bortglömda" IFIn i Europa trots att institutionen funnits under olika beteckningar sedan mitten av 1950-talet. Den vitalisering som skett under det senaste decenniet efter en serie interna problem gör att banken är en mera intressant samarbetspartner. Samtliga nordiska länder har utnyttjat banken för olika sociala projekt. Några av de nordiska länderna har dessutom lämnat bidrag till tekniskt bistånd för beredning av sociala projekt i Öst- och Centraleuropa. Vidare har de nordiska länderna samverkat med CEB för att överföra den "nordiska” modellen för kommunfinansiering till transitionsländer.

De nordiska länderna borde överväga att fördjupa redan existerande samråd för att om möjligt förstärka CEBs insatser i Östersjöregionen liksom i andra medlemsländer i ett utvidgat närområde. CEB är dessutom i behov av ytterligare medel för tekniskt bistånd. Eftersom det rör sig om relativt blygsamma belopp för prioriterade sociala projekt borde en gemensam nordisk insats här vara tänkbar. Även de nordiska finansinstitutionerna, främst NIB, borde sondera möjligheterna att utveckla samarbetet på grundval av den överenskommelse mellan de båda institutionerna som ingicks 2002. NIB har tidigare samverkat med CEB i bl.a. administrativa frågor. Det borde vara möjligt att även utveckla gemensamma projekt i de länder där båda institutionerna kan vara verksamma. 


\section{Modeller för samarbete mellan IFIs}

\subsection{Generella samordningsfrågor}

Medlemsländerna/ägarna i IFIs har varit angelägna att främja ett nära samarbete mellan IFIs för att undvika dubbelarbete och skadlig konkurrens och därmed medverka till effektivare samlade insatser. Samarbetet har underlättats av att mandaten för och kompetenserna hos olika IFIs skiljer sig åt. Det ligger därför ofta i en institutions egenintresse att söka samarbete med andra organ som är verksamma inom samma region.

Samtidigt måste konstateras att interinstitutionellt samarbete inte alltid är enkelt att få till stånd. Det uppkommer ständigt stora eller små revirkonflikter. När det gäller kategorin medelinkomstländer har exempelvis EBRD och IFC haft animerade diskussioner om vem som bör göra vad. Ett problem är att samarbetsavtal som högtidligen etableras på ledningsnivå inte alltid tränger ner till dem som svarar för den operativa verksamheten. $\AA$ andra sidan bör sägas att ett visst mått av konkurrens alltid bör finnas, i alla fall när det gäller enskilda projekt där mer än en institution har förutsättningar att ge efterfrågat stöd. Nederländernas finansministerium har nyligen genomfört en omfattande studie om IFIs roll i medelinkomstländer, i vilken just avvägningen mellan samarbete och konkurrens mellan IFIs tas upp till detaljerad granskning. ${ }^{9}$ Slutsatsen är förord av "kontrollerad konkurrens” innebärande att konkurrens bör tillåtas på marknader som är tillräckligt stora och i sektorer där det inte finns skalekonomier. Vidare konkluderas att konkurrensen inte bör avse priser, standarder och koder eller skyddsregler.

Under senare åren har "påtryckningarna” från ägarländerna om fördjupat IFI-samarbete förstärkts. Det sammanhänger delvis med de övergripande ambitionerna om ökad harmonisering av utvecklingssamarbetet som kommit till tydligast uttryck i den s.k. Paris-deklarationen från 2005. Dessa harmoniseringssträvanden har efter hand kommit att innefatta även samarbetet med medelinkomstländer. Idag råder i stort consensus bland givarna om önskvärdheten av långtgående samordning. Ägarnas krav på fördjupat IFI-samarbete kan också ses som ett uttryck för ett mera systemorienterat angreppssätt. I stället för att bedöma varje institution för sig ser ägarna i växande utsträckning på hur "IFI-familjen” fungerar som

${ }^{9}$ Adding Value to the IFI-system, Report on the Role of the International Financial Institutions in Middle Income Countries, Ministry of Finance, June 2006. 
helhet. Ett sådant förhållningssätt skulle, om det blev mera allmänt förekommande, gagna det multilaterala samarbetet.

För att tillgodose ägarnas krav har det redan komplicerade nätverket av formella samarbetsavtal mellan IFIs gradvis blivit ännu mera invecklat, vilket i sig inte alltid innebär att samordningen i praktiken har fördjupats. Viktigare är sannolikt att det mera operativa harmoniseringsarbetet har utvecklats inom viktiga områden som upphandlingsregler, prissättningsmetoder, miljökonsekvensanalyser, konsultationer av olika intressentgrupper, utvärderingsförfaranden m.m. De tidigare nämnda europeiska miljöprinciperna är ett bra exempel på sådant konkret IFI-samarbete. Försöken att röra sig i riktning mot gemensamma landstrategier är också lovvärda. På sikt borde det vara möjligt att enas om en enda övergripande IFI-strategi för ett land.

Förutom samordning med andra IFIs har finansinstitutionerna under senare år tvingats ägna ökad uppmärksamhet åt samarbete eller koordinering med ytterligare en grupp av multilaterala finansiärer - det växande antalet s.k. vertikala fonder som upprättats särskilt på hälsoområdet. Eftersom detta är en utveckling som främst rör utvecklingsländer berörs den inte närmare här. Det finns dock anledning att ta upp den när EUkommissionens aktiviteter behandlas nedan, eftersom kommissionen nyligen föreslagit ett snarlikt arrangemang i form av en separat investeringsfond för projekt i unionens grannländer.

Slutligen skall framhållas att behovet av IFI-samordning stundom också gäller inom större IFI-koncerner som Världsbanksgruppen. Även på denna punkt pågår ansträngningar att strömlinjeforma enskilda organs verksamheter. För Världsbankens del gäller det speciellt mellan IBRD och IFC där upprepade ansträngningar att utnyttja tänkbara synergier inte gett tillräckliga resultat.

Som noterats tidigare är liknande ansträngningar påkallade inom den nordiska finansgruppen. Beteckningen "nordiska finansgruppen” har inte blivit mycket mer än just en etikett, vilket främst förklaras av ingrott revirtänkande hos de nationella huvudmännen. En institution, Nordiska utvecklingsfonden, som inte närmare behandlas i denna utredning, är under avveckling. De tre övriga samarbetar förvisso i en rad olika praktiska och tekniska frågor, men för en utomstående observatör är det minst sagt svårt att skönja en allmän entusiasm för fördjupat samspel. Vid sidan av ägarländerna måste den stora institutionen - NIB - anses ha ett särskilt ansvar för att skapa en atmosfär som underlättar konstruktivt samarbete inom gruppen. Intrycket är att de två mindre institutionerna NEFCO och Nopef har lättare att enas om gemensamma satsningar än att få till stånd liknande arrangemang med NIB. Det faktum att NIB arbetar med större projekt kan vara en förklaring men knappast hela sanningen. 


\subsection{Modell A - försök till övergripande sektorsvis samordning av samtliga finansiärer}

Project Preparation Committee, PPC, upprättades 1993 vid en konferens med de europeiska miljöministrarna. PPC var avsett att vara en mekanism för att stärka samordningen mellan IFIs och olika givare samt för att underlätta mobiliseringen av resurser till miljöprojekt i Central- och Östeuropa, Kaukasus och Centralasien. Samtidigt antogs ett handlingsprogram som vägledning för miljöreformer i de berörda länderna - Environmental Action Programme, EAP, och en särskild arbetsgrupp - EAP Task Force - tillsattes med uppgift att ge stöd åt reformarbetet.

PPC har varit inriktat på att utveckla och samordna enskilda miljöprojekt. Deltagande står öppet för regeringar, IFIs, andra internationella organ, den privata sektorn, frivilligorganisationer och andra intressenter. Regionala möten har ordnats i en serie mottagarländer för att underlätta samordning. Ett stort antal projekt har passerat igenom PPC under de gångna åren och kommittén har säkert haft betydelse, i synnerhet under de första åren, som ett forum för information och dialog. När planerna på NDEP gjordes upp möttes de med skepsis av nationella biståndsorgan, även i Norden, eftersom samordningen inom ett partnerskap ansågs överlappa arbetet i PPC.

PPC, som har ett litet sekretariat i EBRD, kom dock efter hand att få en andraplansroll som samordningsmekanism. Idag är PPC alltjämt verksamt, men dess betydelse sammanhänger främst med att ett begränsat antal PPC-utsända som finansieras av enskilda givarregeringar, bl.a. i Norden, finns stationerade i IFIs. För närvarande finns sådana utsända enbart i EBRD. Deras uppgift är att söka överbrygga meningsskillnader mellan verksamhetslandet och IFIn och därmed medverka till att påskynda angelägna projekt. Dessutom mobiliseras tekniskt stöd och kompletterande gåvofinansiering till projekt. Därutöver ägnar sig PPC åt allmän informationsverksamhet och kapacitetsbyggande.

Den lärdom som kan dras av erfarenheterna av PPC är att en sådan typ av ambitiös men relativt lös samordning inte blir effektiv. I grunden är givetvis orsaken till detta bristande engagemang hos berörda aktörer. Det förhållandet att PPC/EAP institutionellt hör hemma i OECD har inte heller underlättat samordningsarbetet. Dessutom uppfattas de båda organen som miljöministrarnas redskap och den nationella samordningen i såväl mottagar- som givarländer lämnar även här en del övrigt att önska. PPC utgör numera främst en hjälpfunktion i EBRD. I en nyligen utförd översyn finns idéer om att försöka återskapa en mera självständig roll. Sannolikt kommer dock PPC att i stället formellt integreras i EBRD (s.k. internalisation). Slutligt beslut om PPC's framtid skall fattas vid en miljöministerkonferens i Belgrad i oktober 2007. 
En modell för övergripande samordning av alla aktörer som har visat sig mera framgångsrik är den som tillämpats för olika vattenprojekt i Donau- och Svartahavsregionen. DABLAS Task Force, som har ett synnerligen bred deltagarkrets (inkl. IFIs) och som hålls samman av EUkommissionen, har utarbetat en lista över prioriterade projekt och försöker finna konkreta finansieringslösningar. Ett annat intressant exempel är det ekonomiska samarbetet i Centralasien (Central Asia Regional Economic Cooperation, CAREC). I detta samarbete som inledningsvis koncentrerats till sektorer som energi, transport och handelsfrämjande har Asiatiska utvecklingsbanken lyckats samla deltagande länder, IFIs och andra regionala program inom en enda institutionell ram. Översiktliga investeringsprogram, som ännu är relativt begränsade, har utarbetats. Det principiellt intressanta är att det är en IFI som har lyckats få till stånd en bred samverkan inom en heterogen grupp av intressenter och att denna samverkan kunnat inriktas på konkreta projekt.

\subsection{Modell B - Nordliga dimensionens partnerskap (NDEP, NDPHS, NDTLP)}

Initiativet om en "nordlig dimension" för olika avsnitt av EU's politik lanserades av Finlands statsminister i ett anförande 1997. Efter en serie behandlingar i EU's organ antogs riktlinjer för genomförandet av Nordliga dimensionen vid Europeiska rådets möte i Köln i juni 1999. En första handlingsplan godkändes 2000. Planen, som i ett första skede avsåg perioden 2000-03, täckte en mångfald sektorer såsom energi, transporter, telekommunikationer, miljö och naturresurser, kärnsäkerhet, folkhälsa, handel och investeringar, mänskliga resurser och forskning, inrikesfrågor och gränsöverskridande samarbete. Den geografiska avgränsningen har alltid varit något otydlig. Begreppet anses vanligen innefatta allt från arktiska områden i norr till Östersjöns södra kust i syd samt från nordvästra Ryssland i öster till Grönland och Island i väster. Enligt en bredare definition anses också ytterligare delar av norra Ryssland samt USA och Kanada vara involverade. I sakligt avseende förekommer en verkligt maximalistisk tolkning som inkluderar snart sagt varje verksamhet i norra Europa i Nordliga dimensionen. Denna tolkning gör hela konceptet tämligen meningslöst.

Under det svenska EU-ordförandeskapet första halvåret 2001 lanserades ett första partnerskap inom Nordliga dimensionens ram, miljöpartnerskapet NDEP. Bakgrunden var en önskan att på bred front söka engagera IFIs i miljöprojekt med särskilt stora finansieringsbehov i nordvästra Ryssland. På ordförandeskapets uppdrag arrangerade NIB ett möte med företrädare för ledningarna i EBRD, EIB, NIB och Världsbanken, för EUkommissionen samt för ett fåtal medlemsländer. Möte slutade i enighet om att undersöka förutsättningarna för ett särskilt partnerskap på miljö- 
området på grundval av en skiss som utarbetats av EBRD. Förberedelserna för NDEP genomfördes sedan i ett relativt snabbt tempo. En styrgrupp skapades redan 2001. Under 2002 inrättades en särskild stödfond, NDEP Support Fund, med ett nukleärt fönster och ett fönster för ickeöronmärkta medel, d.v.s. allmänna miljöprojekt. Kombinationen av lån och gåvor för miljöprojekten framstod som nödvändig eftersom alternativen, i första hand ren avgiftsfinansiering, inte var realistiska.

NDEP har otvetydigt blivit en betydande framgång som varit avgörande för realiserandet av ett antal prioriterade miljöprojekt som sydvästra reningsverket i Sankt Petersburg. Det brukar sägas att NDEP hittills banat vägen för projekt om en totalsumma på drygt $€ 2$ miljarder. Här skall inte detaljerna i dessa satsningar behandlas. Den intressanta frågan är i stället: Vilka är skälen till att NDEP som samordnings-förfarande har blivit framgångsrikt? Huvudorsaken är ett starkt engagemang från ett stort antal berörda aktörer och en tydlig ansvarsfördelning. IFIs, i synnerhet EBRD och NIB/NEFCO, har spelat en nyckelroll genom att lägga ner mycket stora ansträngningar på partnerskapet. Varje projekt har en IFI som huvudansvarig. EU-kommissionen och ett dussintal länder, främst i regionen men även andra, har bidragit till stödfonden. Särskilt viktigt har givetvis det ryska engagemanget varit. En annan betydelsefull komponent är det omfattande stöd som några länders nationella biståndsorgan har lämnat. Slutligen har innovativa finansieringslösningar prövats, vilket bl.a. inneburit medverkan från privat sektor i s.k. offentlig privat samverkan, OPS (public-private partnerships, PPPs).

Även organisatoriskt har IFIs fătt en central ställning. NDEP administreras av en styrgrupp bestående av företrädare för IFIs, EUkommissionen och Ryssland med givarländer som observatörer. Ordförandeplatsen innehas normalt av en IFI-företrädare. Gruppen bereder prioritetsordningen för projekten och dispositionen av stödfonden som förvaltas av EBRD. En särskild församling, i vilken samtliga partnerskapsmedlemmar ingår, beslutar om fondens användning och lägger fast mera långsiktiga riktlinjer för partnerskapet. NDEP har dessutom en sekretariatsfunktion i EBRD.

Stundom ges en alltför glättad bild av NDEPs verksamhet som om det varit fråga om en obruten serie av framgångar. Verkligheten är betydligt mera blandad. Svårigheterna att driva ett partnerskap av denna omfattning bör inte underskattas. Implementeringstakten för många projekt särskilt de i Kaliningrad - har varit besvärande låg. Inför framtiden står också NDEP inför svåra utmaningar. Resurserna i stödfonden för miljöprojekt räcker inte till. Diskussionerna om påfyllnad har pågått relativt länge och har gett visst resultat, men ett tillräckligt brett deltagande har ännu inte säkrats. Verksamheten på kärnsäkerhetsområdet, som kompletterar bilateralt samarbete mellan Ryssland och andra länder, har försenats och en strategisk s.k. master plan godkändes först 2004. En samlad utbetalningsplan för detta fönster beräknas vara klar först i augusti 2007. Det 
sammanfattande omdömet måste dock vara att NDEP blivit en stor framgång. Detta har också föranlett partnerländerna i Nordliga dimensionen att framhålla NDEP som en förebild för andra partnerskap.

Partnerskapet för folkhälsa och socialt välbefinnande, NDPHS, upprättades 2003. De blygsamma resultaten av detta partnerskap har redan berörts under avsnitt 5.6 och skall inte upprepas. Som organisatorisk modell är NDPHS inte heller särskilt intressant i detta sammanhang, eftersom samarbetet i hög grad har inriktats på olika regionala organ. Någon stödfond har ännu inte kunnat etableras utan verksamheten har finansierats av enstaka nationella bidrag och medel från EU-kommissionen. IFIs roll för partnerskapet är i det närmaste obefintlig. Ordentliga kontakter med relevanta IFIs har aldrig tagits.

Finlands initiativ om ett partnerskap för transport och logistik, NDTLP, resulterade vid ND-ministermötet i november 2006 till ett uppdrag åt en tjänstemannagrupp att undersöka önskvärdheten av ett sådant partnerskap. I detta syfte skulle också experter och företrädare för IFIs inbjudas. Som redan noterats verkar det finländska förslaget om NDTLP vara baserat på NDEPs framgångsrecept, innebärande bl.a. att IFIs skall ges en central roll. Om utredningsansvaret däremot till stor del läggs på Senior Officials från deltagarländerna kan hela projektet hamna i långbänk. De nordiska länderna bör verka för att de viktigaste IFIs, i det här sammanhanget EBRD, EIB, NIB och Världsbanken, får en mera framskjuten position i beredningsarbetet. Mot denna bakgrund är det lovvärt att ansvariga finländska ministerier redan anlitat NIB för att utveckla NDTLP-konceptet och att det finns planer på att tillsammans med banken ordna möten om partnerskapet.

I ramdokumentet för Nordliga dimensionen för perioden 2007 och framåt framhålls ekonomiskt samarbete, inre och yttre säkerhet, forskning, utveckling och kultur, miljö, kärnsäkerhet och naturresurser samt socialt välbefinnande och hälsovård som prioriterade sektorer. Vidare sägs att partnerskapsmodellen är ett effektivt sätt att organisera implementering av projekt i de prioriterade sektorerna. Samtidigt preciseras en serie tydliga krav. Det understryks att nya partnerskap skall stödjas av ND-medlemmarna, ha säkrat rimlig finansiering redan från början, vara självförvaltande och komplettera de ansträngningar som nationella myndigheter gör. Dessutom skapas en särskild styrgrupp på expertnivå med företrädare för EU, Island, Norge och Ryssland. Gruppen skall säkra kontinuitet mellan minister- och ämbetsmannamötena. ND-modellen har den uppenbara fördelen framför det mest näraliggande alternativet - samarbete inom det strategiska EU-Rysslands-partnerskapet - att även Norge och Island kan delta fullt ut.

Utöver de partnerskap som redan finns eller planeras förefaller forskning och utveckling vara det enda kvarvarande prioriterade område som kunde förtjäna överväganden om ett partnerskap inom ND. Idén har nämnts i tidigare diskussioner men något genomarbetat förslag har, såvitt 
bekant, aldrig framlagts. Under avsnitt 5.6 har liknande förslag om samnordiska insatser på utvecklings/innovationsområdet knutna till en eller ett par IFIs skisserats. Sådana insatser kunde självfallet breddas till att omfatta andra länder i regionen och till att inkludera alla de multilaterala finansiärer som är aktiva inom detta område.

Eftersom ett "innovationspartnerskap" inte finns på listan över framtida utredningsobjekt inom ND är dock sannolikheten låg för att det skulle gå att mobilisera stöd som gör det möjligt att tillgodose ramdokumentets ovanstående krav.

Ett annat försök att stärka Nordliga dimensionen utan att skapa ett fullfjädrat partnerskap är samarbetet inom Northern e-Dimension med tillhörande handlingsplaner, NeDAP. Syftet har varit att påskynda regionens övergång till informationssamhället, att säkra närmare samarbete mellan länderna i regionen samt att förbättra miljön för initiativ och investeringar inom hela IKT-sektorn. Östersjöstaternas råd, och i ett senare skede även Nordiska ministerrådet, har varit huvudansvariga institutioner. Ett antal arbetsgrupper har skapats för olika prioriterade frågor och en särskild grupp med seniora tjänstemän har svarat för övervakningen av handlingsplanens genomförande.

Samarbetet har varit värdefullt genom att det möjliggjort ett informations- och erfarenhetsutbyte, framför allt mellan de mest aktiva deltagarna i Norden och Baltikum. Efter hand har dock arbetet tappat fart. Finansieringsfrågorna har - som ofta är fallet - varit mycket svårlösta. Rysslands relativa ointresse för NeDAP har gjort att EU-kommissionen inte aktivt stött projektet under senare år. Kontakterna med andra internationella aktörer, inklusive IFIs, har varit relativt sporadiska. Strax innan handlingsplanen för 2005-06 utlöpte diskuterades formerna för en eventuell fortsättning. Ett förslag var att CBSS skulle svara för en sammanhållande funktion för de nätverk som skapats genom NeDAP. Någon lösning kunde inte nås, vilket betyder att hela programmet i praktiken suspenderas. Bristen på medel och på effektiv styrning har alltså lett till att ett initialt högt prioriterat samarbete, som NMR t.o.m. beskrivit som ett "nyckelområde", inte förs vidare som ett samlat program.

\subsection{Modell C - formaliserat samarbete mellan en eller flera IFIs och EU-kommissionen}

EU-kommissionen har sedan länge ett välutvecklat samarbete med olika IFIs. Det gäller särskilt EIB/EIF som är unionens egna finansieringsinstrument men också EBRD där kommissionen är en av ägarna och därmed har egen representation i bankens styrande organ. Ett standardupplägg är att kombinera bidragsfinansiering från EU-budgeten med lån som tillhandahålls av EIB/EBRD. Den tendens som har kunnat skönjas under den senaste tiden är att kommissionen söker fördjupa och även formalise- 
ra detta samarbete, vilket är helt i linje med de önskemål om tillväxtorienterade initiativ och ökad samordning som medlemsländerna brukar framföra. Stundom berör dessa ambitioner direkt länderna i Östersjöregionen och dess närområde. I några fall är kommissionens nya samarbetsinitiativ rent komplementära och påverkar inte vad som görs inom t.ex. Nordliga dimensionens ram, medan det i andra fall åtminstone finns risker för konkurrerande upplägg.

Det första exemplet på nya initiativ är JASPERS som är ett stöd till projektförberedelser för nuvarande medlemmar, i första hand av betydelse för transitionsländerna. Ett trepartsavtal har ingåtts mellan kommissionen, EBRD och EIB. Detta samarbete förefaller ha komplementär karaktär och ger potentiella låntagare en möjlighet att få kvalificerad hjälp att utforma tillfredsställande projektförslag. Andra IFIs har för övrigt inbjudits att delta i initiativet.

Det andra exemplet är JEREMIE som är ett sätt för medlemsländer att utnyttja strukturfonds-medel för långsiktig SME-finansiering i samarbete med EIF. Eftersom programmet närmast underlättar medverkan från andra nationella eller internationella finansiärer är det svårt att se att det skulle kunna skapa otillbörlig konkurrens.

Det tredje exemplet är JESSICA - samarbetet med CEB och EIB om projekt avseende förnyelse av stadsmiljöer inom unionen. Kombinationen av medel från EU och lån från bankerna samt åtaganden om förenklade procedurer skall här möjliggöra att angelägna projekt genomförs snabbare. En annan avsikt är att generera finansiering från privata banker. Det nya samarbetet kan eventuellt påverka andra IFIs aktiviteter på området, men det är trots allt CEB och EIB som är de stora aktörerna på detta sakområde.

Det fjärde exemplet är samarbetet kommissionen/EIB/EBRD beträffande samfinansiering av infrastrukturinvesteringar i närområdet. Detta avtal har stundom betecknats som en praktisk arbetsdelning mellan framför allt EBRD och EIB. EBRD står för landanalysen som utnyttjas även av medfinansiären EIB. Avtalet har också beskrivits som ett försök från EBRD att behålla väsentliga delar av sin viktigaste marknad - Ryssland. Den intressanta frågan är hur avtalet kommer att påverka andra IFIs som NIB och Världsbanken. I avsaknad av särskilda arrangemang får dessa institutioner rimligen nöja sig med att överväga medverkan från projekt till projekt. Även om det är för tidigt att bestämt säga hur samarbetsavtalet kommer att slå finns det alltså risk för att det leder till att andra finansiärer, inklusive utanförstående IFIs, får minskade möjligheter att engagera sig i projekt i den aktuella regionen.

Det femte exemplet är kommissionens förslag om en förstärkt grannskapspolitik med ett nytt instrument European Neighbourhood and Partnership Instrument, ENPI. ENPI skall här ersätta tidigare finansieringsordningar som TACIS. Det kommer att ge möjlighet till en rad olika stödformer och inte enbart tekniskt bistånd som tidigare. I den av utredningen behandlade regionen kommer Ryssland, Ukraina och - i framtiden - Vit- 
ryssland kunna få del av ENPI-stöd. Ryssland omfattas visserligen inte av ENP eftersom ett särskilt strategiskt partnerskap ingåtts mellan EU och Ryssland, men konkreta projekt kan trots detta finansieras med medel från ENPI. Det nya instrumentet skall dessutom ses tillsammans med de nya externa lånemandat som godkänts för EIB för period 2007-13 och som möjliggör ökad långivning till bl.a. östländer.

Grannskapspolitiken har medfört att nationella handlingsplaner utformats. Dessa planer har i flera länder integrerats i existerande reformstrategier. Enligt kommissionen har planerna därmed också fått en roll i samordningen med IFIs. Även ENPI föreslås få en form som skall göra det möjligt att länka ihop EUs insatser med IFI-långivning. Kommissionen lanserar två nya finansieringsmekanismer inom ENPIs ram, dels en facilitet som skall ge tilläggsstöd till länder som driver på reformarbetet, dels en stor investeringsfond, Neighbourhood Investment Fund, som just syftar till att stödja IFI-utlåning i partnerländerna. Det är sistnämnda fond som är särskilt intressant i sammanhanget. Den nya fonden skall användas för gåvostöd i samband med utlåning från EBRD, EIB eller möjligen nationella biståndsorgan. Medlemsländerna inviteras att lämna bidrag till den nya fonden, som skall ledas av en särskild styrelse i vilken bidragens storlek föreslås bestämma inflytandet.

Det finns alltjämt flera frågetecken kring detta förslag. Det första gäller återigen att vissa IFIs som Världsbanken eller NIB inte får tillräcklig uppmärksamhet, vilket gör deras status som delfinansiärer oklar. Det andra avser riskerna med att skapa ytterligare en sidoordnad fond med ett antal olika givare och egen styrmekanism. Kommissionens ambition att sätta en tydlig EU-stämpel på samarbetet med grannländerna kan göra det svårt att utveckla ett brett och välfungerande samarbete med samtliga tänkbara långivare.

\subsection{Modell D - samarbete mellan en regional organisation och IFIs}

Metoden att en regional organisation praktiskt samverkar med IFIs i ansträngningarna att utveckla projekt och i nästa fas ordna nödvändig finansiering framstår principiellt som en attraktiv lösning. I praktiken har den dock mycket sällan kommit till användning i Östersjöregionen och dess närområde. Den välvilliga inställning till sådant samarbete som upprepas i allmänpolitiska deklarationer från de regionala organen är uppenbarligen svår att omsätta i handfasta aktiviteter.

Ett betydelsefullt undantag är samarbetet mellan Barentsrådet och NEFCO om identifiering av s.k. hot spots i nordvästra Ryssland samt följande utveckling och prioritering av projekt. Under 2004 upprättades Barents Hot Spot Facility som förvaltas av NEFCO. Ett antal satsningar har redan beslutats dels i form av sektorsstudier, dels mera specifika pro- 
jekt. NEFCO har dessutom fått i uppdrag av Arktiska rådet att hantera en projektberedningsfond i anknytning till programmet Arctic Council Action Plan. Otillräcklig finansiering gör att verksamheten har försenats. Möjligen borde även NIB engageras i arbetet på att hjälpa Arktiska rådet.

De stora regionala råden - NMR och CBSS - har haft ringa framgång i arbetet på att utveckla kontakter och samverkan med de IFIs som är verksamma i Östersjöområdet. När det gäller NMR finns det anledning att göra förnyade ansträngningar för att höja profilen, inte minst för att utveckla samverkan med den nordiska finansgruppen. I framtida nordiska strategier för olika sektorer eller grannländer bör dessutom finansieringsfrågorna tas upp till ordentlig behandling. Konkreta rekommendationer bör ges efter gemensam beredning med bl.a. de ministerier som ansvarar för IFIs verksamhet. För CBSS's del är det mera osäkert om ytterligare försök bör göras för att försöka aktivera detta organs relationer med IFIs. Ovanstående genomgång visar att det i dag finns alternativa - och potentiellt effektivare - mekanismer för att gifta ihop regional kompetens och multilateral finansiering.

\subsection{Slutsatser om IFI-samarbete}

Den självklara utgångspunkten är att låntagarlandets prioriteringar bör vara avgörande i projektvalet och även ha stort genomslag i valet av samarbetspartner/finansiär. Emellanåt har en IFI fått i uppdrag att vara samordnare av det externa stödet, exempelvis Världsbanken vad gäller förvaltningsområdet i Ryssland. Denna uppläggning är dock inte så vanlig längre.

Ovanstående genomgång tyder på att ND-partnerskap och konstellationen EU-kommissionen tillsammans med en eller flera IFIs (KOM+) kommer att vara två viktiga samarbetsmodeller i regionen under de närmaste åren. Konkret samverkan mellan ett regionalt råd och en IFI är i och för sig också en utvecklingsbar modell, men det krävs betydande ansträngningar för att säkra att den framgent skall komma till ökad användning.

Modellerna ND-partnerskap och KOM+ är ingalunda oförenliga. De existerar redan sida vid sida och kan fortsätta att göra så. På vissa avsnitt kan man dock förutse risker för konkurrens. Det gäller särskilt återverkningarna av den typ av samfinansieringsavtal som kommissionen, EBRD och EIB ingått för infrastrukturprojekt i länder utanför unionen. Man kan exempelvis fråga sig om ett partnerskap för transport och logistik kan arbeta smidigt med NDEP som förebild, om några av de tyngsta finansiärerna har ett eget, relativt strikt utformat samarbetsavtal. För de nordiska länderna är det viktigt att agera på ett sätt som gör att man får så mycket som möjligt ut av IFIs resurser och kompetens. Det kan betyda att det är 
lämpligt att inte binda sig vid bestämda institutionella lösningar utan i stället anpassa agerandet efter vad som ger störst utbyte.

EU-kommissionens riktlinjer för ENPI, som innehåller förslag om nya specialfonder, reser också frågor om hur separata fonder med egen beslutsstruktur skall fungera som kompletterande finansiär till IFIs. De nordiska länderna har traditionellt ansett att starka multilaterala institutioner ligger i mindre länders intresse. Det ligger också i vårt intresse att beslut som rör IFIs fattas av institutionernas egna organ och inte i andra grupperingar som G8, G20 eller fristående fondstyrelser. En stor sidoordnad fond, till vilken inte endast EU utan också enskilda medlemsländer förutses bidra, skapar en parallell struktur som å ena sidan kan generera extra resurser och bidra till en harmonisering av EU's och medlemsstaternas insatser. Å andra sidan kan en sådan fond försvåra ett effektivt agerande från IFIs sida. Hur skall en IFI med en mycket bred ägarkrets agera mot en ny aktör som representerar endast en liten grupp av samma ägare och som samtidigt har betydande finansiell styrka? Kommissionens tendens att rangordna IFIs i primära och sekundära partners är också problematisk. Norden har intresse av att alla IFIs som har kompetens och erfarenhet av att verka i regionen uppmuntras att göra detta.

Behovet att ge uttryckligt stöd för vissa finansiella institutioners verksamhet i Östersjöregionen med omnejd förefaller vara särskilt uttalat när det gäller NIB och Världsbanken. Som tidigare framhållits bör de nordiska och baltiska ägarna till NIB verka för att banken försvara sin plats som en av huvudaktörerna i regionen på strategiska områden som infrastruktursatsningar, miljöförbättringar och stöd till SMEs. Detta kan ske genom en formaliserad överenskommelse med övriga IFIs och kommissionen eller genom ett mera informellt arrangemang. Världsbanken befinner sig i en kontraktionsfas i de aktuella transitionsländerna men har ett brett register vad gäller infrastruktur-projekt och dessutom överlägsen kompetens inom en rad sociala områden. Koncentrationen till sociala projekt gör att behovet att additionella gåvobidrag för att uppnå koncessionalitet är särskilt tydligt för Världsbankens del.

Ansvaret för att IFIs utvecklar en välfungerande samordning ligger inte enbart på de exekutiva ledningarna utan också - och sist och slutligen - på ägarna. Som påpekats i annat sammanhang underlättas en samordning på ägarnivån av att det ofta är samma person, d.v.s. finansministern, som företräder ägaren i bankernas högsta beslutande organ, guvernörsstyrelsen. EIB's chef, Philippe Maystadt, tog upp samordningsfrågan i sitt anförande vid bankens årsmöte 2006. Maystadt pekade på den samordnande roll som guvernörerna i institutioner som EIB, EBRD och CEB kunde spela för att skapa bättre sammanhang i genomförandet av EU's externa politik. Exempelvis kunde en förenklad institutionell samordningsfunktion (a light institutional locus) skapas inom vilken medlemsländerna utvecklade ett mera integrerat arbetssätt för att bevilja finansiellt stöd till denna politik. Sådana initiativ bör stödjas av de nordiska länderna. 



\section{Samspel med andra aktörer}

Vid en granskning av vad de nordiska regeringarna kan och bör göra för att bidra till effektivare IFI-insatser i Östersjöregionen och närområdet måste samspelet med ett stort antal andra organ eller intressenter ges uppmärksamhet. Åtskilliga har redan berörts, men det finns ytterligare betydelsefulla aktörer på övernationell, nationell och regional/lokal nivå. En del av dem har regeringarna visst inflytande över, medan andra är i stort sett oberoende såsom fristående nätverk eller frivilligorganisationer. En annan viktig samarbetspartner, som inte alltid ges tillräcklig uppmärksamhet, är den privata sektorn. I detta sammanhang är givetvis privata finansiella institutioner av särskilt intresse. IFIs långsiktiga mål är ju att bli överflödiga och ersättas av andra finansiärer, i första hand av privat karaktär. Denna utveckling är redan på gång, t.ex. genom pågående graduering från Världsbanken.

Avsikten är inte att gå igenom aktörskategorierna i detalj utan snarare att peka på en del frågeställningar som är av vikt för överväganden om hur Norden bör agera för att främja det övergripande målet om effektivare multilaterala insatser.

\subsection{EU och EU-kommissionen}

EU som sammanslutning och EU-kommissionen som initiativtagande institution är självfallet den viktigaste spelaren på övernationell nivå. Kommissionens konkreta samarbete med IFIs har behandlats ovan. De betydande finansiella resurser som EU - och medlemsstaterna - disponerar över via fonder för struktur- eller regionalpolitiska satsningar gör det angeläget att försöka utnyttja kombinationsmöjligheterna mellan nationell, EU- och IFI-finansiering. Men för att bedöma förutsättningarna för sådan samverkan måste mera allmänna frågor om unionens roll i en region som innefattar en tämligen heterogen samling länder beaktas. Åtta länder är fullvärdiga medlemmar, medan två länder har valt att stanna utanför EU. Ryssland har ett speciellt strategiskt partnerskap med unionen om samarbete inom fyra huvudområden (common spaces): yttre säkerhet, inrikespolitiska frågor, ekonomi och forskning/utbildning. Ukraina och Vitryssland omfattas av den nya grannskapspolitiken ENP. Till detta kommer Nordliga dimensionen som har permanentats och som numera anges ha fyra jämbördiga parter, EU, Ryssland, Norge och Island. ND är geografiskt inriktad på nordvästra Ryssland och sakmässigt på de samarbetsområden som identifierats gemensamt. 
EU har alltså inte någon samlad Östersjöpolitik eller strategi för regionen, även om Östersjön och dess miljöproblem lyftes fram som en prioritet i samband med att de nya ND-dokumenten godkändes. Förutom Nordliga dimensionen och partnerskapet med Ryssland - och möjligen EEA för Norges och Islands del - kan frågor som rör Östersjöregionen ses som delar av EUs interna politik på respektive sakområde. Östersjön har, frånsett delar av Ryska federationen, blivit EUs innanhav efter utvidgningen av unionen.

Avsaknaden av en gemensam EU-strategi för Östersjöområdet förefaller tidigare i stort sett ha accepterats av de nordiska länderna. Samtidigt kan hävdas att denna brist inte gör det enklare att driva gemensamma initiativ i regionen. En EU-strategi skulle kunna utgöra en värdefull bas för projekt som kunde få stöd i hela regionen och som dessutom kunde söka finansiering inte enbart från EU-källor utan även från IFIs. En sådan gemensam bas skulle åtminstone delvis kompensera för det faktum att intresset för nya initiativ är starkt varierande med den centrala regeringsnivån i några tunga länder som Tyskland och Polen bland de relativt oengagerade.

Behovet av en EU-strategi har också betonats inom enskilda institutioner, framför allt i Europaparlamentet. I november 2006 godkändes en resolution om en Östersjöstrategi för Nordliga dimensionen. Tanken är att denna strategi skulle förstärka NDs inre pelare och horisontellt täcka olika delar av det regionala samarbetet. Den skulle fungera som ett "paraply" för det dussintal organisationer som är verksamma i regionen och därmed medverka till bättre synergier. Strategin skulle innefatta dels åtgärder som EU och medlemsländerna genomför, dels åtgärder som vidtas i samarbete med Ryssland. Dessutom förordas en särskild budgetpost för strategin som skulle komplettera finansieringen från andra håll, inklusive från IFIs. Vidare understryks behovet av att stärka NDPHS och inrikta det på praktiska åtgärder.

Frågan om parlamentets resolution och agerande kommer att leda till ändringar i EUs nuvarande politik är ännu inte avgjord. De beslut som nyligen har fattats om EUs externa relationer, bl.a. om Nordliga dimensionen, gör att vägen till en samlad Östersjöstrategi blir något mera komplicerad. I NDs ramdokument som gäller från 2007 anges visserligen att Östersjön är ett av de prioriterade områdena för Nordliga dimensionens politik. Detta kan dock knappast ges en tolkning som tillgodoser de viktigaste kraven i Europaparlamentets resolution, särskilt inte önskemålet om en separat budgetallokering. Strategidebatten kommer sannolikt att föras vidare. Vid en parlamentarikerkonferens i Bryssel i februari-mars 2007 konstaterades att inget egentligen hade hänt sedan Europaparlamentets resolution framlagts. Samtidigt upprepades stödet för en Östersjöstrategi för Nordliga dimensionen. Företrädare för parlamentet har dessutom uppvaktat EU-kommissionen, som förefaller vara beredd att överväga frågan på nytt. I deklarationen från CBSS' utrikesministermöte i Malmö i juni 
2007 klargörs dessutom att rådet "skulle välkomna utvecklandet av en strategi för Östersjöregionen med fokus på tydliga prioriteringar".

Därtill bör noteras att senaste omläggning av EUs stöd till gränsöverskridande samarbete inom ramen för struktur- och regionalpolitiken stärker möjligheterna för ett fördjupat samarbete inom Östersjöregionen. Under det nya European Territorial Cooperation Objective har ett särskilt program för Östersjöregionen tillkommit avseende perioden 200713. Detta program finansieras av medel från den Europeiska regionalfonden, från ENPI och bidrag från Norge. Totalt väntas programmet disponera resurser på närmare $€ 240$ miljoner. De strategiska målen för det nya programmet, som helt är inriktat på transnationella aktiviteter, är att främja innovationer i regionen, att förbättra intern och extern tillgänglighet, att söka förvalta Östersjön som en gemensam resurs samt att främja attraktiva och konkurrenskraftiga städer och regioner. Den nya satsningen skall också bygga på de positiva erfarenheterna av tidigare INTERREG-program. Genom detta nya initiativ finns det en "grundplåt" för olika regionala aktiviteter som kan innefatta flertalet länder ${ }^{10}$. Bidraget från ENPI syftar till att underlätta medverkan från Ryssland och Vitryssland. Utöver det samlade Östersjöprogrammet lanserar EU fem andra grannskapsprogram som berör olika gränsregioner i närområdet (Kola/Arktis, Karelen, sydöstra Finland/Ryssland, Estland-/Lettland/Ryssland och Litauen/Polen/Kaliningrad).

När det gäller EUs särskilda partnerskap med Ryssland antog parterna 2005 speciella program eller "vägkartor" för förverkligandet av de fyra gemensamma områden som ingår. Vägkartorna innehåller utförliga förteckningar över konkreta åtgärder som EU och Ryssland är överens om att vidta, men det finns ingen tidtabell och ingen tydlig prioritetsordning. På det ekonomiska området anges bl.a. att parterna är ense om att öka det regionala samarbetets betydelse genom att aktivt stödja gränsöverskridande initiativ och program. I den nordiska diskussionen har ofta framförts att sådana gemensamma åtaganden gör Nordliga dimensionen till ett utmärkt instrument för regionalt eller subregionalt genomförande av vägkartorna. Den ryska federala regeringen har ställt sig bakom insatser som har särskild betydelse för Rysslands nordvästra delar. I den politiska deklaration om Nordliga dimensionen som antogs i november 2006 framhålls också önskvärdheten av att ND-politiken görs till ett regionalt uttryck för de fyra huvudområdena i EU/Rysslands-partnerskapet med fullt deltagande av Island och Norge. Därutöver skall ett antal frågor av speciell relevans för de nordliga områden uppmärksammas.

${ }^{10}$ EUs samfinansiering under de aktuella programmen varierar mellan 50 och 90 procent av projektkostnaderna beroende på vilken/vilka partners som genererat kostnaderna i fråga. 


\section{2 Övriga}

På mellanstatlig nivå finns det vid sidan av de regionala råden, som redan behandlats, ett antal ämnesinriktade samarbetsorgan. HELCOM på miljöområdet och Baltic 21 vad gäller hållbar utveckling i stort är två exempel. Här verkar det redan finnas upparbetade kontakter med IFIs, varför ytterligare gemensamma insatser inte är påkallade. Dessutom finns det multilaterala institutioner utanför IFI-kretsen som ägnar sig åt projekt i regionen såsom FNs utvecklingsprogram och OSSE. Verksamheten är dock av så liten omfattning att den inte motiverar några samnordiska satsningar.

På den nationella nivån i Norden finns biståndsmyndigheter som har fortsatt om än gradvis minskande verksamhet i regionen. Detta bilaterala stöd är ofta ett viktigt komplement till IFI-finansiering. De rent bilaterala satsningarna ligger dock utanför det område som utredningen koncentreras till, d.v.s. tänkbara samnordiska projekt. Samordning av bilaterala insatser är i och för sig en möjlighet och förekommer i mindre omfattning. En mera generaliserad samordning av rent bilateral verksamhet framstår emellertid inte som önskvärd och skulle sannolikt inte ge något tydligt mervärde. Förutom biståndsmyndigheter finns det statsägda eller statskontrollerade bolag som är verksamma på t.ex. riskkapitalområdet i transitionsländerna. Som konstaterats under 5.3 skulle här gemensamma initiativ knutna till en IFI, exempelvis EBRD, kunna övervägas för att höja utväxlingen på tillgängliga medel.

På den regionala/lokala nivån finns det ett synnerligen välutvecklat samarbete. Ett av många exempel är Baltic Sea States Subregional Cooperation, BSSSC, som är ett nätverk av regionala myndigheter och som framför allt ägnat sig åt följa upp hur EUs politik påverkar regionen. Allmänt sett har ett förtjänstfullt beredningsarbete gjorts på många vitala områden alltifrån planering av övergripande infrastrukturbehov till strikt lokala projekt. En betydande del av denna verksamhet har finansierats med EU-medel. Steget från ambitiösa inventeringar till "bankable projects” är dock vanligen relativt långt. Det finns med andra ord inte så många exempel på att subregionala planer/program har kunnat transformeras till projekt som sökt och beviljats finansiering från IFIs. Skälen sammanhänger inte nödvändigtvis med projektens kvalitet utan snarare med att initiativtagarna inte har någon naturlig interlokutör som kan hjälpa till med projektberedningen så att finansieringskontakter kan tas. Detta är säkert ett av skälen till att EU-kommissionen, EIB och EBRD skapat en ny beredningsfacilitet, JASPERS, som skall bistå initiatörerna utan att för den skull IFI-finansiering görs till ett obligatorium.

Särskilt angeläget är att identifiera projekt som binder samman de nordliga delarna av Tyskland och Polen, för vilka Östersjösamarbetet är vitalt, med angränsande delar av regionen. Om NIB gavs en tydligare position som en multilateral Östersjöbank skulle detta kunna vara en prioriterad uppgift för banken. Det har emellanåt spekulerats i möjligheten av 
att formalisera de aktuella regionernas relationer till NIB. Detta förefaller dock uteslutet; en samverkan får baseras på helt informella arrangemang.

Bland de många fristående nätverk som upprättas för Östersjöregionen förtjänar Baltic Development Forum, BDF att framhållas. Forumet är inte enbart en viktig mötesplats för olika intressenter från privat och offentlig sektor utan svarar också för värdefull utredningsverksamhet, bl.a. i form av en regelbunden State of the Region Report. Denna rapport ger ett bra underlag för överväganden om vad som bör prioriteras i arbetet på att främja tillväxt och regional integration. Ett återkommande tema i rapporten är behovet av nationella och gränsöverskridande åtgärder för att utveckla kluster, främja entreprenörskap och stärka utbildning och forskning. BDF har dessutom ett stort antal sponsorer i Östersjöländerna. Ett brett och välfungerande nätverk av detta slag borde kunna användas för att initiera och utveckla mera konkreta projektförslag som i nästa steg behöver multilateral finansiering.

BDF har även medverkat till att lansera Baltic Sea Initiative, BSI. Detta nätverk av nätverk skall arbeta för att främja konkurrenskraft och hållbar tillväxt. Nätverket är öppet för alla organisationer som är intresserade av att arbeta aktivt med Östersjöfrågor. Under 2006 har BSI letts av NMRs generalsekreterare med inriktning på att förbättra förutsättningarna för att bilda industriella kluster, marknadsdriven innovation, forskningssamarbete, integrering av finansiella marknader och marknadsföring av regionen. Inom BSIs ram genomförs projekt som syftar till att allmänt stärka innovationskapaciteten (BSR InnoNet) eller till att förbättra villkoren för användar/konsumentdrivna innovationer. BSI följer också upp initiativ inom övriga prioriterade områden, bl.a. med hjälp av regelbundna möten. Initiativet är allmänt sett lovvärt, men resultaten verkar hittills vara blygsamma.

Ett konkret exempel på nätverk inom BSI som fått praktisk betydelse är dock ScanBalt. Det övergripande syftet med detta samarbete, som bygger på ett aktivt samspel mellan universitet, näringsliv och myndigheter, är att utveckla en globalt konkurrenskraftig region inom livsvetenskaper/bioteknik. Efter en uppbyggnadsperiod omfattar nätverket nu ett stort antal institutioner som bedriver en aktningsvärd verksamhet. ScanBalt-konceptet har utvecklats med stöd från bl.a. Nordisk InnovationsCenter och EU-budgetens forskningsmedel.

När det slutligen gäller privat sektor är självfallet en aktiv medverkan från näringslivet i de nordiska länderna av helt avgörande betydelse för att olika integrationsfrämjande initiativ skall nå resultat. Samtliga IFIs samverkar i varierande former med den privata sektorn. Generellt sett är dock kunskaperna om IFIs verksamhet otillräckliga hos nordiska företag. Regeringarna och myndigheterna har fortsatt en uppgift när det gäller att bedriva informationsverksamhet och t.ex. upplysa om nya låneordningar eller samarbetsmöjligheter. De nordiska länderna har också anledning att samråda om former för ett mera effektivt informationsarbete, eventuellt 
med ledning av vad andra jämförbara industriländer gör för att sätta IFIs på kartan.

Utrymme för att utveckla samarbetet med IFIs finns också mera specifikt för privat finansiell sektor i Norden. Förutom i traditionell samfinansiering har bankerna en väsentlig roll att fylla som mellanhänder för IFIs utlåning till t.ex. små och medelstora företag. Allt sådant samarbete bör självfallet bedömas på kommersiella grunder av varje privat institution. Det är dock angeläget att nordiska finansiella institutioner uppmärksammar aktuella tendenser i riktning mot ökad diversifiering inom flera IFIs. Instrumentarsenalen utvidgas, i många fall på ett sätt som underlättar medverkan från privata banker eller privata investerare i enskilda transaktioner. Av särskild betydelse är att nya metoder för riskhanteringen ${ }^{11}$ arbetas fram. I flertalet IFIs pågår en sådan utveckling för att stärka den katalytiska effekten gentemot andra finansieringskällor. Det gäller exempelvis ett strategiskt område som forskning och utveckling.

${ }^{11}$ Jfr The Untapped Potential of Development Finance Institutions to Catalyze Private Investments, World Economic Forum, 2006. 


\section{Behov av riktade insatser avseende enskilda länder eller delregioner}

I ovanstående diskussion har avsiktligt utelämnats vilken geografisk täckning enskilda samnordiska initiativ skall ha. Det finns ett brett spektrum av möjligheter alltifrån projekt som innefattar samtliga länder i "storregionen" (Östersjön och närområdet) till specifika subregionala eller lokala initiativ. Täckningen är i hög grad beroende av projektens inriktning. Om de nordiska länderna exempelvis gemensamt driver etablerandet av ett partnerskap för transport och logistik är det för att få till stånd ett samarbete som innefattar regionens alla länder. Eventuella satsningar på utvecklings- och innovationsområdet med IFI-medverkan bör ha samma täckning. Övergripande miljöinitiativ är ytterligare ett exempel.

Om det däremot är fråga om stöd till specifika reformansträngningar är den traditionella modellen att de fem nordiska länderna samarbetar med en IFI för insatser i en eller flera östländer såsom skedde i Baltiska investeringsprogrammet. Tonvikten i sådana förslag i utredningen ligger på samnordiska lösningar, d.v.s. på "givarsidan” står samtliga fem länder bakom projektet. Det är naturligtvis tänkbart att endast två eller tre nordiska länder samverkar i ett IFI-relaterat projekt, men den typen av mera ad hoc-betonade arrangemang ligger utanför det område som utredningen koncentreras till.

På "mottagarsidan” i nyssnämnda projekt kan dock variationsrikedomen vara stor. Norden kan etablera en stödfond i t.ex. EBRD som kan användas i alla länder där banken är verksam eller enbart i vissa utpekade länder. I andra IFIs inskränks användningsområdet med automatik på grund av utformningen av bankens mandat. Den fråga de nordiska länderna bör ta ställning till i detta sammanhang är om det finns behov av riktade insatser till enskilda länder eller delregioner. Det måste bedömas $\mathrm{i}$ ljuset av redan pågående aktiviteter som i hög grad koncentreras till nordvästra Ryssland.

Enligt utredningen bör sådana riktade gemensamma insatser övervägas i första hand gentemot Ukraina och Kaliningrad. Ukraina står utanför samarbetet i Nordliga dimensionen och är endast observatör i CBSS. Samtidigt är Ukraina i praktiken det enda landet i regionen som omfattas av EUs grannskapspolitik, eftersom ENP-samarbetet med Vitryssland inte har aktiverats. En handlingsplan som godkänts av EU och Ukraina håller på att genomföras. Den nya grannskapspolitiken syftar till att stärka det regionala och subregionala samarbetet. ENPI skall kunna finansiera 
gemensamma program som för samman regioner i medlemsstaterna med regioner i partnerländer som Ukraina. Detta skall ske enligt en förenklad procedur som baseras på flerårig programmering och samfinansiering. Gränsöverskridande samarbete under ENPI kommer bl.a. att samfinansieras av Europeiska regionalfonden. Totalt sett kommer EUs finansiella stöd till Ukraina att öka väsentligt under perioden 2007-10.

Ukraina strävar för egen del efter att integreras i det europeiska samarbetet med sikte på EU-medlemskap. Landet anser sig tillhöra " $a$ broader Baltic Sea Region”. Flertalet nordiska länder har redan bilaterala samarbetsprogram med Ukraina. Samarbetet är särskilt betydelsefullt inom områdena energieffektivisering och miljö. På ett övergripande plan har de nordiska länderna ett gemensamt intresse att medverka till att underlätta Ukrainas fortsatta integrering. Frågan är hur en samverkan skulle kunna utformas.

I Ukraina fastlades under 2006 en strategi för samarbetet med IFIs. Strategin har i stor utsträckning karaktären av en önskelista, vilket bl.a. betyder att man inte har kommit särskilt långt i prioriteringsarbetet. En mera genomarbetad strategi kan väntas framkomma som ett resultat av pågående samarbete med IFIs, framför allt EBRD/EIB. En förteckning över angelägna infrastrukturprojekt håller på att upprättas i samarbete med dessa banker. Ukraina har dessutom nyligen skapat sektorsspecifika organ för samråd med externa finansiärer. I ljuset av en utförlig strategi och den omfattande ENPI-satsningen kunde specifika nordiska punktinsatser identifieras i syfte att underlätta utformningen och beredningen av konkreta projekt. Samtliga IFIs planerar en expansion av aktiviteterna i Ukraina. EBRD och EIB har redan inlett den utvidgade gemensamma satsningen. Utveckling av transportkorridorer i såväl nord-sydlig som väst-östlig riktning via Ukraina har av den ukrainska regeringen framhållits som en särskilt angelägen satsning.

Kaliningrad har sedan länge varit ett prioriterat område för gemensamma nordiska satsningar. I riktlinjerna för NMRs samarbete med nordvästra Ryssland 2006-08 betonas Kaliningrads särställning. Det anges att samarbetsbehovet är betydande och att Kaliningrads utveckling är av stor vikt för grannländerna Polen och Litauen. De nordiska länderna har spelat en viktig roll i samband med miljöprojekt i Kaliningrad inom NDEP's ram. En erfarenhet av dessa projekt är att genomförandet blir synnerligen komplicerat, vilket leder till omfattande förseningar. Oklarheter i ansvarsuppdelningen mellan olika nivåer är en förklaring. Om Norden och andra länder i regionen skall medverka i nya satsningar i Kaliningrad bör det föregås av tydligare åtaganden från framför allt ryskt federalt håll att underlätta ett samarbete.

I EU's indikativa program för samarbetet med Ryssland under perioden 2007-10, där insatser framgent skall finansieras via ENPI, understryks att unionen har ett särskilt intresse för Kaliningradområdet. I programmet pekas på riskerna för att en negativ utveckling i detta område 
kan hämma tillväxten i andra delar av regionen. EUs aktiviteter kommer primärt att avse olika former av kapacitetsbyggande inom förvaltning, korruptionsbekämpning, miljöskydd och hälsovård. EU har öronmärkt drygt € 50 miljoner i stöd till Kaliningrad för perioden 2007-13.

Additionella insatser måste, liksom i fallet Ukraina, självfallet utgå från mottagarlandets prioriteringar. Från rysk sida har man vid vissa tillfällen framfört tanken om att Kaliningrad-området skulle kunna vara bas för vissa pilotprojekt i arbetet på att utveckla ett närmare samarbete med EU. Inom en sådan ram borde även förstärkt medverkan från IFIs och från de nordiska länderna prövas. Den politiska ledningen för Kaliningrad-regionen har nyligen pekat på fyra prioriteter i utvecklingsarbetet: 1) Transportsektorn, inklusive sammankoppling till övriga europeiska transportnät, 2) Livsmedelindustrin, 3) Turism och 4) Utökat bostadsbyggande. Till det bör läggas att en av Kaliningrad-regionens uppenbara svagheter i strukturhänseende är att man har en synnerligen obetydlig småföretagssektor. 



\section{Rekommendationer och förslag till strategi}

Utredningens rekommendationer indelas, liksom framställningen i övrigt, i ett antal huvudkategorier. Den inledande gäller rekommendationer avsedda att stärka det nordiska inflytandet i IFIs genom ett fördjupat samarbete och ett mera proaktivt arbetssätt i dessa institutioner. Därefter följer förslag till samnordiskt agerande på olika sakområden i anknytning till olika IFIs verksamhet. Nästa kategori är rekommendationer avseende enskilda institutioner eller samarbetet mellan IFIs följt av förslag om samspel med andra aktörer samt om vissa geografiska prioriteringar inom den samlade regionen. Slutligen skisseras riktlinjer för den fortsatta behandlingen av förslagen.

Rekommendationerna presenteras här i starkt komprimerad form. Summan av dessa rekommendationer utgör ett förslag till nordisk strategi för att effektivisera de multilaterala insatserna i Östersjöregionen och dess närområde. Strategin grundar sig på bedömningen att det behövs en nordisk kraftsamling för att vitalisera samarbetet i regionen. Om denna bedömning inte delas av samtliga nordiska länder, finns det givetvis inte skäl att gå vidare med strategiarbetet. En sådan slutsats - innebärande att tillräckliga gemensamma intressen inte finns - borde dock också leda till en mera fundamental omprövning av pågående verksamheter.

När det gäller formerna för genomförande av förslagen finns det inte några universallösningar. Varje insats måste anpassas till de specifika institutionella förutsättningarna. Förutom nordisk enighet som grund krävs det ett gemensamt agerande i många olika sammanhang - i IFIs, i EU, i Nordliga dimensionen, i de regionala råden och gentemot de fristående nätverken för Östersjöregionen. De samnordiska - eller nordisk/baltiska - instrumenten bör dessutom utnyttjas mera kraftfullt än i dag för att höja profilen.

\subsection{Förslag till åtgärder för mera effektiva och målinriktade arbetsformer i IFIs}

Utredningen föreslår att de nordiska länderna:

- utarbetar övergripande strategier för de internationella finansinstitutioner som är verksamma i Östersjöregionen och dess närområde. Sammanställningen av dessa strategier bör ske nationellt men kan kombineras med ett nära nordiskt eller nordiskt/baltiskt samråd 
- utvecklar ett närmare och kontinuerligt samråd mellan berörda ministerier och/eller myndigheter i varje nordiskt land för att främja ett välkoordinerat uppträdande och undvika dubbelarbete. När det gäller IFIs är en väsentlig uppgift att informera bättre om och få ökad förståelse för den strategiska betydelse de har i det regionala ekonomiska samarbetet. Denna uppgift ligger i första hand på ansvariga ministerier

- såväl på det nationella planet som i mellanstatliga diskussioner verkar för ökad interaktion mellan IFIs och regionala samarbetsorgan. Mötena med Östersjöländernas finansministrar bör utnyttjas i detta syfte

- lägger om arbetssättet gentemot IFIs innebärande färre detaljinstruktioner till omedelbart förestående styrelsemöten och flera genomarbetade policypapper i mycket tidigare skeden av beredningsprocessen

- ger styrelserepresentanterna i IFIs betydligt ökad frihet att agera inom ramen för sådana policydokument, t.ex. att föra diskussioner med staben eller att diskutera gemensamma utspel med kolleger. I IFIs utan gemensam nordisk representation kan ett motsvarande samarbete baseras på överenskommelser i strategiska frågor där Norden har starka intressen. Institutionernas verksamhet i Östersjöregionen och dess närområde är ett typexempel på en sådan fråga

- främjar ett samråd över institutionsgränserna och ett mera systemorienterat arbetssätt genom att medverka till regelbundna kontakter eller möten mellan nordiska styrelserepresentanter i de IFIs som är verksamma i regionen.

\subsection{Förslag till samnordiska insatser inom olika sakområden i anknytning till IFIs verksamhet}

Grundkrav för samnordiska insatser är att de ger ett mervärde och att det föreligger en tydlig trilateral intressegemenskap mellan Norden, IFIs och berörda samarbetsländer. Utredningen föreslår att de nordiska länderna:

- prioriterar de tre sakområdena miljö, transporter och forskning/utveckling/innovation i överväganden om gemensamma nordiska satsningar kopplade till IFI-verksamhet i regionen. Även inom andra sektorer kan åtgärder vara befogade men då mera som punktinsatser

- inom miljösektorn bygger vidare på Nordliga dimensionens framgångsrika miljöpartnerskap, NDEP. Detta kan främst ske genom att överväga ytterligare bidrag till NDEPs stödfond inom ramen för en påfyllnad kännetecknad av rimlig bördefördelning och brett regionalt deltagande 
- hävdar att NDEP fortsatt bör ha ett brett verksamhetsområde inkluderande exempelvis energieffektivisering och samtidigt medverkar till att formerna för hanteringen av mindre projekt utreds närmare

- söker ge IFIs en framträdande roll i utformningen av HELCOMs handlingsplan för Östersjön. Detta gäller primärt finansieringsfrågorna i vilka NEFCO redan engagerats

- gör ytterligare ansträngningar för att involvera IFIs i Baltic 21:s projektverksamhet och i miljösatsningarna inom Barentsrådet och Arktiska rådet

- utnyttjar NEFCO för ytterligare riktade miljösatsningar i regionen, t.ex. utvidgning av handel med utsläppsrätter till nya områden

- på transportområdet medverkar till att IFIs kompetens utnyttjas på bästa sätt. I såväl inhemska som gränsöverskridande projekt bör alternativa lösningar prövas förutsättningslöst, bl.a. efter inhämtande av synpunkter från relevanta IFIs

- aktivt stödjer förslaget om ett partnerskap för transport och logistik inom ramen för Nordliga dimensionen (NDTLP) med EUkommissionen och IFIs som centrala aktörer. IFIs bör i ett sådant partnerskap få en roll som liknar den de tilldelats i NDEP

- verkar för att såväl regionens som nordiska transportpolitiska prioriteter får genomslag i bredare TEN-T-diskussioner

- medverkar till att också intressen hos länder i Östersjöregionens närområde beaktas i detta sammanhang speciellt vad gäller paneuropeiska transportkorridorer

- när det gäller forskning/utveckling/innovation inleder överläggningar med EIF om tänkbar utformning av en nordisk (eller nordisk-baltisk) venture capital-fond för SMEs av det slag som skisserats i en särskild nordisk utredning

- inleder diskussioner om en motsvarande fond i EBRD för projekt i regionen utanför Norden och Baltikum. Medverkan av nationella riskkapitalinstitut och NEFCO bör ingå i dessa överväganden

- låter utreda i detalj hur kopplingar mellan EU-budgetens resurser (sjunde ramprogrammet för forskning samt programmet för konkurrenskraft och innovation) kan kopplas ihop med IFIs låne- och garantikapacitet för projekt i regionen

- ger i uppdrag åt NIB att se på möjligheterna att fördjupa det regionala samarbetet på sakområdet med hjälp av innovativa finansieringsinstrument (vid sidan av venture capital). Uppdraget kan delfinansieras från den nordiska budgeten

- på övriga sakområden i huvudsak agerar inom ramen för existerande samarbetsarrangemang. På hälsoområdet behöver det nuvarande partnerskapet NDPHS reaktiveras. I dessa ansträngningar bör ingå att undersöka möjligheterna till samråd/samarbete med IFIs, främst Världsbanken. Det suspenderade samarbetet om Northern eDimension bör bli föremål för en genomgång för att klarlägga om vissa värdefulla 
delar kan föras vidare, eventuellt med en begränsning av antalet deltagande länder.

\subsection{Förslag avseende enskilda IFIs roller i regionen}

Utöver ovan redovisade förslag knutna till specifika sakområden framläggs rekommendationer om nordiskt agerande för att medverka till effektivare insatser från enskilda IFIs. Utredningen föreslår att de nordiska länderna:

- välkomnar det fördjupade samarbetet mellan EBRD, EIB och EUkommissionen som ett exempel på konkret samverkan mellan viktiga finansiärer i syfte att effektivisera stödet till bl.a. länder i Östersjöregionen och dess närområde. Nya samarbetsinstrument som t.ex. JASPERS bör utnyttjas för större och komplicerade projekt i syfte att påskynda genomförandet

- samtidigt verkar för att Världsbanksgruppen skall förbli en viktig aktör i regionen och att bankens komparativa fördelar och kompetens utnyttjas på dess traditionella verksamhetsområden. EBRD/EIB/Kommissionens överenskommelse om samfinansiering av infrastrukturprojekt i Ryssland m.fl. länder får inte leda till att andra aktörer hålls utanför

- på liknande sätt verkar för att NIB får möjlighet att delta i större projekt i de aktuella länderna. I detta syfte bör konkreta diskussioner inledas mellan NIB och parterna i nyssnämnda överenskommelse. På sikt bör eftersträvas att NIBs verksamhet går mot ökad specialisering antingen som "Östersjöbank" eller som primäransvarig för delsektorer i regionen, t.ex. inom kommunal infrastruktur

- utnyttjar NEFCOs specialkompetens genom att stödja att bolaget engagerar sig i nya verksamhetsområden eller utvecklar nya instrument

- som ägare till den nordiska finansgruppen medverkar till fördjupat samarbete och ökad integrering inom gruppen. Det bör vara möjligt att utnyttja synergier på det sätt som NEFCO och Nopef håller på att genomföra. Gruppen bör också förses med tillräckliga resurser för tekniskt stöd. Detta kan ske antingen genom interna omdispositioner eller externa bidrag

- uppmärksammar CEB som tänkbar finansiär i delar av regionen och medverkar till att banken kan genomföra projektberedande arbete i medlemsländer i och utanför regionen. 


\subsection{Förslag avseende samordning mellan IFIs och samspel med andra aktörer}

Utredningen konstaterar att Nordliga dimensionens partnerskap och konstellationen KOM+ (EU-kommissionen samt en eller flera IFIs) är de bäst fungerande samordningsmodellerna. Även om de båda modellerna kan fungera sida vid sida finns det risk för obefogad konkurrens om de kommer till användning på samma sakområde. Av särskild vikt blir då ett systemorienterat synsätt så att samtliga i regionen verksamma IFIs ges möjlighet att utnyttja sina komparativa fördelar. Utredningen föreslår i övrigt att de nordiska länderna:

- generellt uppmuntrar ökad IFI-samordning och ansträngningarna att leva upp till internationella överenskommelser om harmonisering av stödet till medelinkomst- och utvecklingsländer

- driver att IFIs verksamhet skall styras av de egna organen och genomföras enligt godkända handlingsplaner. Fristående fonder med egna styrorgan bör endast få en kompletterande roll

- aktivt stödjer samarbete mellan regionala organisationer och en eller flera IFIs. NEFCOs samverkan med BEAC/AC är ett av de alltför få exemplen på denna kombination. NMR bör integrera finansieringsfrågorna $\mathrm{i}$ sitt framtida strategiarbete avseende Östersjön och närområdet samt fördjupa dialogen med nordiska finansgruppen. CBSS' roll på de ekonomiska och finansiella områdena är däremot otydlig och bör omprövas

- stödjer idén om att man på ägarnivån i IFIs försöker utveckla ett mera sammanhållen syn på IFIs verksamhet. Även här kan mötena med Östersjöregionens finansministrar utnyttjas. EIB-chefens förslag om ett "light institutional locus" kan också tjäna som vägledning

- följer upp förslagen om en gemensam EU-strategi för Östersjöregionen samt därvid söker hävda regionala intressen och prioriterar regionala initiativ inom unionens ram som utnyttjar kombinationsmöjligheter mellan nationell, EU- och IFI-finansiering

- utnyttjar fristående nätverk och sammanslutningar för att öka engagemanget hos de länder som är relativt "passiva" deltagare i Östersjösamarbetet och för att driva regionala lösningar som innefattar IFI-medverkan

- stärker informationen till och kontakterna med privata aktörer för att öka kunskapen om IFI-finansiering och särskilt om pågående utveckling av nya instrument för riskdelning som kan underlätta privat samfinansiering. Erfarenheter från andra jämförbara industriländer bör beaktas i detta sammanhang. 


\subsection{Förslag avseende riktade insatser för enskilda länder eller delregioner}

Utredningen har identifierat två prioriterade geografiska områden för gemensamma insatser: Ukraina och Kaliningrad. Utredning föreslår att de nordiska länderna:

- allmänt verkar för att Ukraina knyts närmare till samarbetet i Östersjöregionen. När det gäller IFIs verksamhet kan Norden på olika sätt medverka till att landets intressen beaktas i olika gränsöverskridande program, exempelvis på infrastrukturområdet. Vidare kan de nordiska länderna och NIB vara en diskussionspartner för Ukraina i arbetet på att utforma en samlad strategi för landets samarbete med IFIs. Slutligen kan gemensamma punktinsatser övervägas för att underlätta projektberedning, exempelvis i anknytning till EUs utvidgade finansiella stöd till landet. Riktat stöd till småföretagsutveckling är en annan möjlighet

- utnyttjar existerande påtryckningsmöjligheter för att påskynda genomförandet eller planeringen av beslutade projekt i Kaliningrad, exempelvis inom NDEPs ram. Samtycke till nya insatser inom partnerskapets ram kan exempelvis villkoras med att konkreta framsteg görs i Kaliningrad. Dessutom bör prioriteringen av Kaliningrad i Nordliga dimensionen utnyttjas för att lansera konkreta utvecklingsprojekt. Utökat stöd till utveckling av SMEs via finansiella mellanhänder bör exempelvis övervägas inom ramen för NIB eller EBRD.

\subsection{Förslag till fortsatt behandling}

Ett eventuellt godkännande av den föreslagna strategin eller väsentliga delar av den bör kombineras med ett beslut av finansministrarna (MRFinans) om hur uppföljning bör ske. Som redan understrukits finns det ingen enkel modell för att säkra genomförandet. Tvärtom krävs det att gemensamma initiativ tas på en rad olika sakområden i ett antal fora. Vidare förutsätter strategin agerande såväl på det nationella planet som på samnordisk nivå.

Det föreslås att ÄK-finans får i uppdrag att svara för den övergripande uppföljningen av strategins genomförande. Kommittén bör ha en sammanhållande snarare än en direkt operativ roll. Huvudansvaret för genomförandet av enskilda åtgärder bör i stället läggas på nationella ministerier/myndigheter som i nästa steg rapporterar till landets ledamot i ÄKfinans för redovisning där. I detta arbete bör också existerande nordiska samarbetsorgan engageras. 
Förslagen under 10.1 om effektivare arbetsformer i IFIs bör exempelvis behandlas i nordisk/baltiska bankgruppen och i motsvarande organ för IMF. I andra institutioner utan gemensamma valkretsar bör de nordiska styrelserepresentanterna beredas möjlighet att yttra sig i särskild ordning innan de tas upp till vidare behandling.

Förslagen under 10.2, som kan ses som de tyngsta i utredningen, bör bli föremål för ingående nationellt samråd mellan berörda fackministerier och ekonomi/finansministerierna. I nästa skede krävs kontinuerliga kontakter med företrädare för samarbetsländerna och för IFIs. Ett positivt ställningstagande från MR-Finans' sida hösten 2007 bör endast ses som ett klartecken att gå vidare med analys och överläggningar. NMR-sekretariatet bör i samråd med ÄK-finans lägga upp en plan för beredningsarbetet.

Förslagen under 10.3 och 10.4 är i första hand en fråga för de ministerier som har ansvaret för IFIs i fråga men förutsätter i flera fall också samråd nationellt. Förslagen i 10.5 slutligen berör kanske primärt utrikesoch ekonomi/finansministerierna. Dessutom krävs även här fördjupade kontakter med såväl samarbetsländer som IFIs. Det förefaller naturligt att de nordiska styrelseföreträdarna i IFIs även på samtliga dessa avsnitt får möjlighet att yttra sig i särskild ordning.

ÄK-finans bör - på grundval av de nationella redovisningarna - i nästa steg sammanställa en rapport om hur strategin har genomförts. I uppdraget till ÄK-finans bör ingå att en sådan återrapportering skall lämnas till MR-Finans’ möte ett år efter det att en strategi har antagits. 



\section{Summary of the Nordic Inquiry on More Efficient Multilateral Action in the Baltic Sea Region and Neighbouring Areas}

The aim of this inquiry, conducted at the request of the Nordic Council of Ministers, is to present a comprehensive set of proposals for a strategy for the Nordic countries' cooperation in multilateral activities in the immediate region. Of primary interest are the most important international financial institutions (IFIs) such as the European Bank for Reconstruction and Development, the European Investment Bank, the World Bank Group, the Nordic Investment Bank, the Nordic Environment Finance Corporation and the Council of Europe Development Bank. Relations with other important players such as the European Commission and cooperation in the numerous regional bodies are also considered.

The acceleration of economic and financial integration under way in the Baltic Sea Region, especially with the enlargement of the EU, forms the background to this inquiry. Another important new factor is the agreement on permanent cooperation in the Northern Dimension framework, in which all Nordic countries are full participants. The changes taking place affect the IFIs' activities and require almost constant adjustments on their part. Estonia, Latvia and Lithuania have already decided to stop borrowing from the World Bank. In the European Bank for Reconstruction and Development, a plan winding up its activities in new EU member countries has been agreed. At the same time the European Investment Bank's importance as a source of financing both within and outside the EU is increasing. It is thus an appropriate time for a broad review ot the Nordic countries' cooperation in and with IFIs with the aim of finding ways to use resources effectively and efficiently and adopting innovative solutions. In addition there is a need for a comprehensive approach to the multilateral programmes that the Nordic countries support in the region.

The Inquiry's recommendations are divided among a number of different sections. The first section presents proposals for a more proactive and goal-oriented role in the IFIs. There is a proposal to raise the Nordic countries' profile based on comprehensive national strategies and on joint Nordic policy documents. Board members in IFIs should be given more 
freedom to act within the framework of joint Nordic policy initiatives. The importance of much better consultation among the ministries concerned in each country is also stressed. Lingering turf wars lessen Nordic countries' chances of making an impact in these institutions.

The second section presents proposals on the areas that should be given priority. Three areas are emphasised: the environment, transport and the "cluster" research/development/innovation. Addressing environmental matters, the report emphasises the importance of continuing to build the Northern Dimension Environmental Partnership and developing the activities of the Nordic Environment Finance Corporation. In the transport sector, the report recommends that the Nordic countries support the initiative on a special partnership for transport and logistics. As to innovation, the report recommends establishing Nordic (or Nordic-Baltic) venture capital funds in the European Investment Fund and the European Bank for Reconstruction and Development. Concrete proposals in other areas are also presented, mostly in the form of specific measures.

The third part of the Inquiry's recommendations concerns the roles of individual IFIs in the region. The strengthened cooperation among certain European IFIs is a welcome development, but it should not lead to the exclusion of other institutions from important projects. It is in the Nordic countries' interest that all funding bodies with the relevant competence be able to work in the region. The World Bank Group continues to be an important actor in countries such as Russia and the Ukraine. It is particularly important that the Nordic Investment Bank be given the room it needs for its operations, which - in the view of the Inquiry - should become more specialised. Greater integration of the Nordic financial institutes is also urgently needed.

A fourth section considers IFI coordination and interaction with other players. The Nordic countries should start with a systems-oriented approach. The IFIs' activities should be determined by their own bodies in stead of being dictated by separate funds with their own decision-making structure. More use should be made of independent parties and networks, particularly in Baltic Sea countries that are relatively passive participants in the regional cooperation. In addition, information to private actors and funding bodies and contacts with them should be improved with the aim of achieving the catalytic effects made possible by IFI participation. The fifth section discusses specific geographic priorities. It recommends considering directed measures, above all for the Ukraine and for the Kaliningrad area.

Following the presentation of the report, the recommended way forward would be a combination of a possible ministerial decision on a renewed strategy and a decision on what kinds of follow-up there should be. The Inquiry proposes that the Committee of Senior Officials-Finance generally follow up on the implementation of the strategy. However, responsibility for implementing various parts of the strategy must lie 
primarily with the national public administrations in conjunction with existing Nordic consultative bodies, for example, for certain IFIs. In some cases the preparation of proposals will take a relatively long time. This is especially true of proposals that have to be built on a trilateral community of interests involving the Nordic countries, other countries affected by the new actions and the IFIs concerned. There needs to be extensive discussion of these points before specific proposals can be presented for approval. The Inquiry recommends that the Committee of Senior OfficialsFinance report back to the Council of Ministers-Finance one year after the approval of an overall strategy. 



\section{Bilaga 1 - Förkortningar}

$\begin{array}{ll}\text { AC } & \text { Arktiska rådet } \\ \text { ADB } & \text { Asiatiska utvecklingsbanken } \\ \text { BaltMet Inno } & \text { Innovationssamarbete mellan Östersjöregionens } \\ & \text { storstäder } \\ \text { BASREC } & \text { Östersjöregionens energisamarbete } \\ \text { BDF } & \text { Östersjöns utvecklingsforum } \\ \text { BEAC } & \text { Barentsrådet } \\ \text { BIP } & \text { Baltiska investeringsprogrammet } \\ \text { BSI } & \text { Östersjöinitiativet } \\ \text { BSR INNOnet } & \text { Östersjöregionens nätverk för innovationer } \\ \text { CAREC } & \text { Centralasiens regionala ekonomiska samarbete } \\ \text { CBSS } & \text { Östersjöstaternas råd } \\ \text { CEB } & \text { Europarådets utvecklingsbank } \\ \text { CIP } & \text { EUs konkurrenskrafts- och innovationsprogram } \\ \text { DABLAS } & \text { Samarbete om vattenprojekt i Donau- och Svarta havs- } \\ & \text { området } \\ \text { EAP } & \text { Miljöhandlingsprogrammet för östländer } \\ \text { EEA } & \text { Europeiska ekonomiska området } \\ \text { EBRD } & \text { Europeiska utvecklingsbanken } \\ \text { EIB } & \text { Europeiska investeringsbanken } \\ \text { EIF } & \text { Europeiska investeringsfonden } \\ \text { ENP } & \text { EUs partnerskap med grannländer } \\ \text { ENPI } & \text { ENPs finansieringsinstrument } \\ \text { EU } & \text { Europeiska unionen } \\ \text { GEF } & \text { Globala miljöfonden } \\ \text { HELCOM } & \text { Helsingforskommissionen } \\ \text { IBRD } & \text { Världsbanken (verksamhet i medelinkomstländer } \\ \text { IFC } & \text { Internationella finansieringsbolaget (i Världsbanks- } \\ & \text { gruppen } \\ \text { IFI } & \text { Internationella finansiella institutioner (mellanstatliga } \\ \text { IMF } & \text { organ) } \\ \text { JASPERS } & \text { Internationella valutafonden } \\ \text { JEREMIE } & \text { Gemensamt projektstöd i europeiska regioner } \\ \text { JESSICA } & \text { Gemensamma europeiska resurser för stöd till små och } \\ \text { KOM+ } & \text { medelstora företag } \\ \text { MIGA } & \text { Gemensamt europeiskt stöd till hållbara investeringar i } \\ & \text { EU-kommåden } \\ & \text { Multilateral investeringsgarantiorganet (i Världsbanks- } \\ & \end{array}$




$\begin{array}{ll}\text { MR-finans } & \text { Nordiska ministerrådet (finansministrarna) } \\ \text { ND } & \text { Nordliga dimensionen } \\ \text { NDEP } & \text { Nordliga dimensionens miljöpartnerskap } \\ \text { NDF } & \text { Nordiska utvecklingsfonden } \\ \text { NDPHS } & \text { Nordliga dimensionens partnerskap för folkhälsa och } \\ & \text { socialt välbefinnande } \\ \text { NDTLP } & \text { Nordliga dimensionens partnerskap för transport och } \\ & \text { logistik } \\ \text { NeDAP } & \text { Nordliga dimensionens handlingsplan för e-samarbete } \\ \text { NEFCO } & \text { Nordiska miljöfinansieringsbolaget } \\ \text { NIB } & \text { Nordiska investeringsbanken } \\ \text { NICe } & \text { Nordisk InnovationsCenter } \\ \text { NIF } & \text { Nordisk investeringsfond (förslag) } \\ \text { NMR } & \text { Nordiska ministerrådet } \\ \text { Nopef } & \text { Nordiska projektexportfonden } \\ \text { NORIA } & \text { Nordiska forsknings- och innovationsområdet } \\ \text { OECD } & \text { Organisationen för ekonomiskt samarbete och utveckling } \\ \text { OECD/DAC } & \text { OECDs kommitté för utvecklingsbistånd } \\ \text { OSSE } & \text { Organisationen för säkerhet och samarbete i Europa } \\ \text { PPC } & \text { Projektberedningskommittén (på miljöområdet) } \\ \text { PPP } & \text { Offentlig-privat samverkan } \\ \text { ScanBalt } & \text { Nätverk för samarbete inom livsvetenskaper/bioteknik } \\ \text { SMEs } & \text { Små och medelstora företag } \\ \text { TACIS } & \text { EUs tekniska bistånd till OSS-länder } \\ \text { TEN-E } & \text { Transeuropeiska nätverk på energiområdet } \\ \text { TEN-T } & \text { Transeuropeiska nätverk på transportområdet } \\ \text { TGF } & \text { Regional klimatfond förvaltad av NEFCO } \\ \text { ÄK-finans } & \text { Nordiska ämbetsmannakommittén för ekonomiska och } \\ & \text { finansiella frågor }\end{array}$




\section{Bilaga 2 - Korta fakta om IFIs som verksamma i östersjöregionen och dess närområden}

\section{Europeiska utvecklingsbanken, EBRD}

Banken har sitt huvudkontor i London och inledde sin verksamhet 1991. Den har som huvudsakligt syfte att medverka till övergången till marknadsekonomi i Central- och Östeuropa samt i det forna Sovjetunionen. Bankens medlemmar utgörs av 61 länder samt EU och EIB. Samtliga nordiska och baltiska länder är medlemmar. Verksamheten är primärt inriktad på att bidra till att utveckla den privata sektorn. Banken arbetar med en bred uppsättning instrument alltifrån traditionell långivning till riskkapital i olika former. Stadgan föreskriver att banken kan samarbeta endast med länder som respekterar demokratiska principer. EBRDs totala affärsvolym 2006 uppgick till € 4,9 miljarder.

\section{Europeiska investeringsbanken, EIB}

EIB är EUs finansieringsinstitution som upprättades genom Romfördraget. Huvudkontoret är beläget i Luxemburg. Medlemmar i EIB är EUs medlemsstater och huvuddelen av bankens finansieringsverksamhet äger rum inom unionen. Banken har dock en jämförelsevis omfattande utlåning till andra länder enligt särskilt fastställda mandat. Exempelvis sker utlåning till Island och Norge inom ramen för ett mandat för EFTAländerna. Bankens väsentliga uppgift är att bidra till integration samt ekonomisk och social sammanhållning inom unionen genom långfristig projektfinansiering. Verksamheten spänner över ett stort antal områden men EIB har haft särskild betydelse för stora infrastrukturprojekt inom transport, telekommunikationer och energi, forskning och utveckling, stöd till småföretag via mellanhänder samt på senare tid även gränsöverskridande miljöprojekt. Banken har också successivt ökat risktagandet $\mathrm{i}$ sin utlåningsverksamhet. EIBs samlade utlåning 2006 (godkända projekt) uppgick till ca $€ 46$ miljarder, vilket gör banken till världens största IFI. 


\section{Europeiska investeringsfonden, EIF}

EIF är den andra delen av "EIB-gruppen” och har specialiserat sig på stöd till SMEs. Fonden, som också är lokaliserad till Luxemburg och som inledde verksamheten 1994, ägs av EIB, EU (representeras av kommissionen) och ett drygt tjugotal finansiella institutioner i medlemsländerna. EIF investerar i riskkapitalfonder (venture capital) som stödjer SMEs samt erbjuder kreditgarantier eller värdepapperisering för sådana företag. Fonden investerar alltså inte direkt i småföretag. Fonden använder inte enbart egna resurser utan förvaltar också medel som ställts till dess förfogande av t.ex. kommissionen. Inom ramen för sistnämnda verksamhet sker investeringar även i icke-EU länder som Island och Norge. EIFs affärsvolym (undertecknade transaktioner) uppgick under 2006 till inemot $€ 700$ miljoner vad gäller venture capital och drygt $€ 2$ miljarder vad gäller garantier.

\section{Världsbanksgruppen}

Gruppen består av fem olika organ - Internationella återuppbyggnadsbanken, IBRD, Internationella finansieringsbolaget, IFC, Multilaterala investeringsgarantiorganet, MIGA, Internationella utvecklingsorganet, IDA och Internationella centret för lösande av investeringstvister, ICSID. Av dessa behandlas endast de tre förstnämnda i rapporten. IDAs verksamhet förbigås eftersom den är inriktad på fattiga u-länder och ICSIDs aktiviteter berör inte de frågor som tas upp i utredningen.

\section{IBRD}

IBRD är gruppens ursprungliga institution som upprättades 1944. Banken med huvudkontor i Washington, D.C. ägs av 185 medlemsländer. Samtliga nordiska och baltiska länder är medlemmar men utnyttjar inte IBRD som långivare. Verksamheten är numera inriktad på finansiering (lån och garantier) till medelinkomstländer samt utvecklingsländer med god kreditvärdighet. Vid sidan av långivningen har bankens analys- och rådgivningstjänster kommit att spela en viktig roll för mottagarländerna. Volymmässigt har utlåningen från IBRD stagnerat under senare år, vilket bl.a. sammanhänger med att allt fler länder kunnat tillgodose sina finansieringsbehov på den privata marknaden. För det senaste finansåret 1 juli 2005-30 juni 2006 uppgick IBRDs samlade finansiering till drygt USD 14 miljarder. 
IFC

IFC, som är gruppens organ för privatsektorutveckling, startade sina aktiviteter 1956. Bolaget har numera 179 medlemmar och har - parallellt med EBRD - fullgjort en viktig funktion i östländernas övergång till marknadsekonomi, bl.a. genom att utveckla innovativa finansiella instrument. IFCs största enskilda landexponering i dag avser Ryssland. IFCs samlade finansiering (egna åtaganden) uppgick under 2005-06 till ca. USD 7 miljarder.

\section{MIGA}

MIGA. som tillkom 1988, har som viktigaste uppgift att främja utländska direktinvesteringar i utvecklingsländer genom försäkringar mot olika slag av politisk risk. Antalet medlemmar uppgår i dag till 170. I MIGAs portfölj är garantier till regionen Europa och Centralasien den volymmässigt största komponenten. Infrastrukturutveckling är ett prioriterat område för MIGA.

\section{Nordiska investeringsbanken, NIB}

NIB inledde sin verksamhet 1976 som ett finansieringsinstrument för investeringar som främjar tillväxt i Norden. Banken - med huvudkontor i Helsingfors - hade ursprungligen de fem nordiska länderna som medlemmar. Från 2005 ingår även de tre baltiska länderna i medlemskretsen. Banken finansierar projekt såväl i som utanför medlemsländerna. Enligt en aktualiserad strategi skall NIB prioritera insatser som stärker medlemsländernas konkurrenskraft och som förbättrar miljön. Fyra prioriterade områden anges: infrastruktur, miljöförbättrande investeringar, stora investeringar i företagssektorn samt stöd till SMEs via mellanhänder. NIBs samlade utlåning under 2006 uppgick till $€$ 1,6 miljarder.

\section{Nordiska miljöfinansieringsbolaget, NEFCO}

Bolaget etablerades 1990 av de fem nordiska länderna. Huvudkontoret är beläget i Helsingfors. NEFCO är en riskkapitalinstitution som finansierar miljöinvesteringar i Östeuropa. Ett huvudsyfte är att underlätta miljöförbättrande projekt i närområdet och därigenom uppnå positiva miljöeffekter för Norden. Förutom den ursprungliga investeringsfonden förvaltar NEFCO ett flertal specialfonder, bl.a. för mjuk finansiering och en regional klimatfond. Under 2006 godkändes totalt 60 projekt under de olika fonder NEFCO förvaltar. 


\section{Nordiska projektexportfonden, Nopef}

Fonden beviljar lån och stöd till nordiska SMEs för förstudiekostnader i samband med internationell etablering och projektexport. Projekten skall avse östra Europa utanför EU. Fram till utgången av 2007 kan även stöd till projekt avseende Polen och de baltiska länderna beviljas. Syftet med Nopefs stöd är att stärka de små företagens internationella konkurrenskraft. Fonden har under senare tid stärkt sitt fokus på Nordvästryssland och på innovativa SMEs. Nopef samverkar med övriga nordiska finansinstitutioner som NIB och NEFCO.

\section{Europarådets utvecklingsbank, CEB}

Banken, som upprättades under annat namn redan 1956, är Europarådets finansieringsinstrument med uppgift att verka inom främst tre områden: social integration, stöd till miljöförbättrande åtgärder och utveckling av humankapitalet (utbildning och hälsovård). Banken har sitt huvudkontor i Paris och har för närvarande 39 medlemmar. CEB kan ge lån endast till medlemsländer. Detta betyder att banken inte är aktiv i länder som Ryssland och Ukraina. Däremot har de nordiska länderna lånat från CEB. Bankens totala lånevolym (godkända projekt) under 2006 uppgick till $€$ 2,5 miljarder. 


\section{Bilaga 3 - Referenser}

Inom ramen för utredningen har ett stort antal samtal förts med företrädare för länder, internationella institutioner, privat sektor och fristående nätverk. Eftersom ett av utredningens huvudsyften har varit att kritiskt granska de multilaterala aktiviteterna i regionen, vilket inneburit att varje samtalspartner uppmuntrats att öppet redovisa sin syn, anges inte här namnen på de personer som intervjuats. För att ge en översiktlig bild av den insamling av underlag som ägt rum kan i stället diskussionerna indelas i samtal med företrädare för:

- nordiska länder, i första hand direkt berörda ministerier som finans/ekonomi och utrikes, men också en rad specialministerier med ansvar för miljö-, transport- och hälsovårdsfrågor

- länder i närområdet, inkl. i samband med en särskild "fact finding"resa till Ukraina

- andra länder som under senare tid genomfört större studier av IFIs, t.ex. Nederländerna, Storbritannien, Österrike

- regionala organ som NMR, CBSS och BEAC

- EU-kommissionen

- Norden eller Norden/Baltikum i alla berörda IFIs

- staberna eller sekretariaten i nämnda IFIs, såväl företrädare för ledningen som experter på olika sakområden

- särskilda projektberedande organ som PPC

- privat sektor, i första hand finansiell sektor

- subregionala samarbetsorgan och fristående nätverk i samband med konferenser inriktade på Östersjöregionen, t.ex. Baltic Development Forums ”toppmöten". 